\title{
COMMENT
}

\section{T-TIP NEGOTIATIONS ROUND TWO: AN OPPORTUNITY TO REDIRECT THE TRAJECTORY OF INTERNATIONAL INVESTMENT LAW}

\section{NICHOLAS WIGGINS ${ }^{\dagger}$}

Over 2,500 international investment agreements govern trillions of dollars in foreign direct investment that crisscrosses the globe. Nonetheless, the international investment law regime formed by those agreements faces a legitimacy crisis. Critics argue that international investment treaties' dispute-resolution mechanisms favor foreign investors and that their substantive obligations undermine countries' sovereignty. As the world's largest exporters and recipients of foreign direct investment, the European Union and United States hold the keys to reform. Until now, however, they have differed on solutions. A well-designed investment chapter in a free trade agreement between the European Union and United States could simultaneously resolve those differences and redirect the trajectory of international investment law.

INTRODUCTION

1291

I. BACKGROUND: THE E.U. AND U.S. POSITIONS ON INVESTOR-

STATE DiSPUTE SETTLEMENT IN CONTEXT............................1295

A. International Investment Law at a Crossroads .............................. 1295

B. The E.U. Experience with Investor-State Dispute Settlement ........... 1302

1. The EuropeanUnion's Evolving ISDS Policy from 2010 to

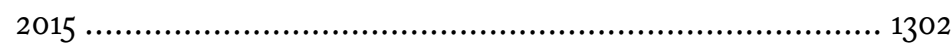

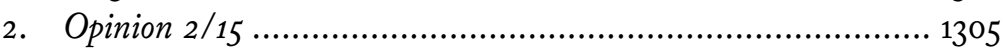

3. Achmea .......................................................... 1306

† Senior Editor, Volume 169, University of Pennsylvania Law Review; J.D. Candidate, 2021, University of Pennsylvania Law School; B.A., 2011, Hamilton College. I thank Professor R. Daniel Kelemen for helping me to develop the genesis of this Comment in his Fall 2019 seminar on European Union law. Special thanks to all the editors of the University of Pennsylvania Law Review for their thorough review and editing of this Comment. All errors are my own. 
4. CETA and Opinion 1/17

1309

a. Structure and Content of the CETA Investment Chapter ... 1309

b. Opinion $1 / 17$.

1312

C. The U.S. Experience with Investor-State Dispute Settlement

1313

1. From NAFTA to T-TIP .............................................1314

2. T-TIP Round One ..........................................1318

3. The Turn in U.S. International Investment Policy ............ 1320

4. The Relevance of the U.S. Position on the WTO's

Appellate Body

II. ENHANCING THE LEGITIMACY OF INTERNATIONAL INVESTMENT LAW AND PROTECTING TRANSATLANTIC INVESTMENT THROUGH AN E.U.-U.S. IIA .......................... 1327

A. The Rationale for Investor-State Dispute Settlement in an E.U.-

U.S. FTA

1. Strengthening the Legitimacy of International Investment

Law

2. The Importance of Bilateral Investment Between the

European Union and United States................................ 1329

B. The Design of an E.U.-U.S. FTA Investment Chapter......................1335

1. Dispute Settlement .....

a. Traditional Ad Hoc Arbitration in the First Instance ..........1335

b. The Appellate Mechanism

1337

i. The Opt-In Appellate Instrument Establishing the Appellate Mechanism at ICSID ...................1341

ii. The Pool of Appellate Adjudicators.................... 1344

iii. The E.U.-U.S. IIA Language ........................... 1344

iv. The Appellate Mechanism Illustrated.................. 1346

2. Substantive Provisions 1346

a. E.U. and U.S. Formulations of the Fair and Equitable

Treatment Standard in Existing International Investment

Agreements 1347

b. The Formulation of the Fair and Equitable Treatment Standard the European Union and United States Should Include in an E.U.-U.S. IIA 1350

i. Prescribing the Sufficient Conditions for a FET Breach. 1350

ii. Codifying the Legitimate Expectations Principle.. 1354

iii. Providing for General Exceptions that Parallel Those Found in the WTO Agreements ............... 1356

III. IMPLICATIONS OF THIS COMMENT'S PROPOSAL...................1360 
"[W]hen borders are crossed, arbitration offers the crucially important advantage of forum neutrality-parties can appear before a neutral decision maker without having to be hauled into the other's courts."

- U.S. Supreme Court Associate Justice Stephen Breyer ${ }^{1}$

\section{INTRODUCTION}

Despite the operation of more than $2,500^{2}$ international investment agreements (IIAs), ${ }^{3}$ most of which include an investor-state-dispute settlement (ISDS) ${ }^{4}$ mechanism allowing investors to allege host-state 5 breaches of the IIAs, international investment law sits at a crossroads. The crescendo of opposition to ISDS has built to a fever pitch over the past several

1 STEPHEN BREYER, THE COURT AND THE WORLD 180-81 (2015).

2 This figure was calculated by adding the total number of bilateral investment treaties in force to the total number of treaties with investment provisions in force. See International Investment Agreements Navigator, UNITED NATIONS CONF. ON TRADE \& DEV., https://investmentpolicy.unctad.org/internationalinvestment-agreements [https://perma.cc/Y9YU-K4DC].

3 Treaties that provide reciprocal investment protection to investors include (1) bilateral investment treaties (BITs), see Bilateral Investment Treaties, OFF. OF THE U.S. TRADE REPRESENTATIVE, https://ustr.gov/trade-agreements/bilateral-investment-treaties [https://perma.cc/ $\mathrm{NW}_{7} \mathrm{~F}-68_{3} 6$ ], and (2) free trade agreements (FTAs) with investment chapters, see Free Trade Agreements, OFF. OF THE U.S. TRADE REPRESENTATIVE, https://ustr.gov/trade-agreements/free-trade-agreements [https://perma.cc/ $\mathrm{H}_{2} \mathrm{NY}$ $\left.{ }_{7} \mathrm{D}_{2} \mathrm{~J}\right]$. In accordance with literature on international investment law, this Comment usually refers to these agreements as IIAs, except when referring to BITs or FTAs makes sense in context.

4 For a discussion of IIAs containing ISDS mechanisms that the European Union has been party to, see infra Section I.B., and for a discussion of IIAs containing ISDS mechanisms that the United States has been party to, see infra Section I.C. Although ISDS technically refers to the specific arbitration procedure that investors can access to challenge state breaches of substantive investment protections covered in an IIA, procedural and substantive provisions of IIAs are widely referred to under the same rubric of ISDS in contemporary debate and scholarship. Thus, this Comment uses the ISDS acronym to refer to both procedural and substantive provisions of IIAs, unless otherwise specified. It uses the phrase "ISDS mechanism" when referring specifically to the particular dispute settlement procedure under which investors may sue states. According to United Nations Conference on Trade and Development's (UNCTAD) Investment Policy Hub, 2,443 of the 2,577 treaties it has mapped contain ISDS mechanisms. See Mapping of ILA Content, U.N. CONF. ON TRADE AND \& DEV., https://investmentpolicy.unctad.org/international-investment-agreements/iiamapping [https://perma.cc/KEQ3-N4GX].

5 As in other areas of international law, in international investment law, the term "state" is used to refer to the term "country." For example, the Convention on the Settlement of Investment Disputes Between States and Nationals of Other States describes countries that are signatories to the Convention as "Contracting States." See Convention on the Settlement of Investment Disputes Between States and Nationals of Other States pmbl., Mar. 18, 1965, 17 U.S.T. 1271, 1272 [hereinafter ICSID Convention]. This Comment therefore primarily uses the term "state," but, where appropriate, uses "country" as a synonym. The term "host state" refers to the country in which a foreign investor invests. The term "home state" refers to the state of which the foreign investor is a national. 
years-especially as developed countries have concluded more IIAs with each other and have increasingly found themselves defending against ISDS claims. ${ }^{6}$

Critics of ISDS register various procedural and substantive grievances. On procedure, they argue that ISDS lacks transparency, democratic accountability, and a mechanism to correct erroneous arbitral decisions. On substance, they contend that ISDS infringes states' right to regulate, includes vague investment protection standards that are interpreted inconsistently, and gives foreign investors advantages over domestic investors.

In light of this legitimacy crisis, an investment chapter in a free trade agreement (FTA) between the United States and European Union-which would cover roughly $\$ 4.5$ trillion in cumulative transatlantic foreign direct investment (FDI) 7 -would provide a vehicle to redirect the trajectory of international investment law and deepen the E.U.-U.S. economic relationship.

Such an FTA would revive the Transatlantic Trade and Investment Partnership (T-TIP), a comprehensive FTA that the European Union and United States began negotiating in 2013 but then paused in 2016, partly because of differences over ISDS.8 Specifically, the United States balked at the European Union's proposed inclusion of an Investment Court System in the FTA's investment chapter. ${ }^{9}$ Attempts to revive T-TIP negotiations have sputtered, as the two sides have sparred over discrete trade issues and have prioritized the conclusion of FTAs with other trading partners. 10

6 See infra notes 43-52 and accompanying text (discussing disputes in which countries like Canada, the United States, and Germany found themselves as respondent parties); infra note 142 and accompanying text (explaining that the United States began responding to ISDS disputes after the North American Free Trade Agreement entered into force).

7 ShaYerah Ilias AKHTAR, CONG. RsCH. SERV., IF10930, U.S.-EU TRADE AND INVESTMENT TIES: MAGNITUDE AND SCOPE 1-2 (2020). This figure excludes the bilateral investment relationship between the United States and United Kingdom.

8 See Shayerah Ilias Akhtar \& Vivian C. Jones, Cong. Rsch. SerV., IF10120, TRANSATlantiC TRADE AND INVESTMENT PARTNERSHIP (T-TIP) 1 (2017) ("Sticking points [between the European Union and United States] remain in other hotly contested areas, such as geographical indications (GIs), digital trade, and investor protections."); The Transatlantic Trade and Investment Partnership (TTIP), EUR. COMM'N, https://ec.europa.eu/trade/policy/in-focus/ttip [https://perma.cc/8BK8-W8B3] ("The TTIP negotiations were launched in 2013 and ended without conclusion at the end of 2016.").

9 Krista Hughes \& Philip Blenkinsop, U.S. Wary of EU Proposal for Investment Court in Trade Pact, REUTERS, (Oct. 29, 2015, 3:01 PM), https://www.reuters.com/article/us-trade-ttipidUSKCNoSN2LH20151029 [https://perma.cc/EE8Y-UQUR] ("The United States is wary of a European Union proposal for a new court system to settle investment disputes as part of the world's biggest free-trade agreement, U.S. Trade Representative Michael Froman said.”).

10 In particular, the European Union and United States have struggled to resolve longstanding World Trade Organization (WTO) disputes involving subsidies supplied by the European Union and United States to Airbus and Boeing, respectively. See generally Bryce Baschuk, Why the Boeing vs. Airbus Fight Is Coming to a Head, WASH. POST (Oct. 1, 2020), https://www.washingtonpost.com/business/why-theboeing-vs-airbus-fight-is-coming-to-a-head/2021/01/06/d53ec5ca-502d-11eb-a1f5-fdaf28cfca9o_story.html 
Nonetheless, given the size of the E.U. and U.S. economies and the volume of their bilateral trade and investment, both sides have signaled their interest in eventually resuming full-fledged FTA negotiations.11 And as of this Comment's publication, the European Union and the Biden Administration have signaled their commitment to intensifying E.U.-U.S. economic cooperation.12

Despite the opportunity presented by an investment chapter in an E.U.U.S. FTA, the path toward its conclusion is unclear, as the European Union and United States have adopted differing approaches to remedying their perceived shortcomings of the current international investment law regime. Since 2015, the European Union has insisted on including an E.U.-developed Investment Court System-instead of traditional, ad hoc investor-state arbitration-in all its IIAs. ${ }^{13}$ The Investment Court System model reflects the European Union's view that having ISDS claims heard under a structure that resembles a domestic court-including an appeals mechanism-will enhance international investment law's legitimacy. Over the past several years, the European Union has included the Investment Court System in IIAs negotiated with Canada, Singapore, and Vietnam. ${ }^{14}$ Ultimately, the European Union envisions the treaty-by-treaty Investment Court System structures merging into a Multilateral Investment Court.

[https://perma.cc/8HT7-JPZ7] (explaining the longstanding WTO dispute between the European Union and United States about the subsidies they have provided to Airbus and Boeing, respectively).

11 For example, the United States and the European Union concluded a small trade deal in August 2020 that provided U.S. lobster exports with better market access to the European Union, in exchange for better market access for certain E.U. exports to the United States. See Joint Statement of the United States and the European Union on a Tariff Agreement, OFF. OF THE U.S. TRADE REPRESENTATIVE (Aug. 21, 2020), https://ustr.gov/about-us/policy-offices/press-office/pressreleases/2020/august/joint-statement-united-states-and-european-union-tariff-agreement [https://perma.cc/G ${ }_{5} \mathrm{UU}-\mathrm{T}_{7} \mathrm{RL}$ ] (noting that the trade agreement arose out of congressional and presidential directives to negotiate a trade agreement with the European Union).

12 See, e.g., A New EU-US Agenda for Global Change, at 1, JOIN (2020) 22 final (Dec. 2, 2020) (explaining that given the size and volume of the E.U.-U.S. economic relationship, the European Union and United States should set "a new transatlantic agenda for global cooperation" (emphasis omitted)); Press Release, Off. of the U.S. Trade Representative, Readout of Ambassador Katherine Tai's Virtual Meeting with European Commission Executive Vice-President Margrethe Vestager (Mar. 29, 2021), https://ustr.gov/about-us/policyoffices/press-office/press-releases/2021/march/readout-ambassador-katherine-tais-virtual-meeting-europeancommission-executive-vice-president-o [https://perma.cc/RUU2-GRUB] ("[U.S. Ambassador Katherine] Tai outlined her strong desire to develop a more positive and productive trade relationship with the European Union.").

13 The development of the E.U. position on ISDS in IIAs is discussed at length in infra Section I.B.

14 Comprehensive Economic and Trade Agreement (CETA), Can.-European Union § F, Oct. 30, 2016, 2017 O.J. (L 11) 23 [hereinafter CETA]; Annex to the Proposal for a Council Decision on the Conclusion of the Investment Protection Agreement between the European Union and Its Member States, of the One Part, and the Republic of Singapore of the Other Part § A, COM (2018) 194 final (Apr. 18, 2018); Annex to the Proposal for a Council Decision on the Conclusion of the Investment Protection Agreement between the European Union and Its Member States, of the One Part, and the Socialist Republic of Viet Nam of the Other Part § B, COM (2018) 693 final (Oct. 17, 2018). 
Conversely, the United States has responded to criticisms of ISDS by removing the ISDS mechanism between the United States and Canada, and narrowing its application between the United States and Mexico in the United States-Mexico-Canada Agreement (USMCA).15 Although various U.S. presidents and Congresses have contemplated an appellate mechanism for ISDS disputes, ${ }^{16}$ the United States has never taken concrete steps toward establishing such a mechanism in any of its IIAs.

Against this challenging backdrop, this Comment provides a pragmatic roadmap for how the United States and European Union can reconcile their positions on international investment law and negotiate an IIA that will provide a model on which future IIAs can be built. First, it claims that the combination of ad hoc arbitration with an appellate mechanism embedded in the World Bank's International Centre for Settlement of Investment Disputes (ICSID) would remedy many of the procedural challenges that international investment law faces. Second, it argues that an E.U.-U.S. IIA could resolve lingering uncertainty in international investment law about the scope and content of substantive investment protections.

The Comment proceeds as follows. Part I discusses the history of ISDS, its foreign policy and economic rationales, and the nature of the legitimacy crisis it faces. It then explains the E.U. experience with ISDS and examines how the European Union's political and legal institutions have developed the European Union's current position on ISDS. In turn, Part I addresses the U.S. experience with ISDS and U.S. responses to criticism of ISDSespecially in light of the recently concluded USMCA and the U.S. critiques of the World Trade Organization's (WTO) Appellate Body.

Part II advances the proposed structure of an investment chapter in an FTA between the European Union and United States. Specifically, it focuses on how an ISDS mechanism with traditional, ad hoc arbitration in the first instance, coupled with an appellate mechanism located within ICSID, would operate and resolve legitimacy concerns. Part II also explains how the proposed investment chapter would respond to perceived flaws in the substance of international investment law by clarifying the scope and content of core investment protection standards. Part III discusses the implications of this Comment's proposed investment chapter structure, with an emphasis on institutional and strategic challenges that the proposal might introduce.

15 The USMCA is the successor agreement to the North American Free Trade Agreement. It entered into force on July 1, 2020. United States-Mexico-Canada Agreement, OFF. OF THE U.S. TRADE REPRESENTATIVE, https://ustr.gov/trade-agreements/free-trade-agreements/united-statesmexico-canada-agreement [https://perma.cc/F2SS-J766].

16 See infra notes 171-73, 176 and accompanying text (discussing the U.S. model bilateral investment treaties' consideration of appellate mechanisms). 


\section{BACKGROUND: THE E.U. AND U.S. POSITIONS ON INVESTOR- STATE DISPUTE SETTLEMENT IN CONTEXT}

This Part uses the historical development of ISDS to define the boundaries within which the European Union and United States can negotiate a legitimacy-enhancing IIA. First, it examines the main rationales for ISDS and the nature of its legitimacy crisis. Second, it considers the European Union's experience with ISDS, demonstrating how the European Union evolved into the global champion for an Investment Court System. Third, it analyzes the U.S. experience with ISDS and why the current U.S. position on ISDS must be understood in light of its denunciation of the WTO's Appellate Body.

\section{A. International Investment Law at a Crossroads}

ISDS has long been used as a tool to advance states' foreign policy and economic interests. ${ }^{17}$ Before examining the criticisms leveled against ISDS, it is necessary to explain the foreign policy and economic rationales that led to its development and that remain ongoing justifications for its use.

From a foreign policy perspective, ISDS has been justified as a way to guarantee that a home country's investors receive certain core standards of legal protection when investing in another country, without needing the home country to intervene on its investors' behalf when disputes arise. ${ }^{18}$ Indeed, a multilateral desire to end the aggressive intervention of developed states on behalf of their investors in the first half of the twentieth century-so-called gunboat diplomacy-motivated the development of the ISDS regime.19

Home-state interference in investment disputes in the absence of IIAs has continued into the twenty-first century. For example, consider the U.S. Section 301 investigation into China's measures related to the forced technology transfer of U.S. companies investing in China. Under Section 301 of the Trade Act of 1974, the Office of the U.S. Trade Representative (USTR) may investigate whether another country imposes an "unreasonable or

17 See, e.g., Shayerah Ilias AKHTAR \& Martin A. Weiss, Cong. RSCH. SerV., R43052, U.S. INTERNATIONAL INVESTMENT AGREEMENTS: ISSUES FOR CONGRESS 17 (2013) ("U.S. investment negotiations can help to advance U.S. trade, foreign policy, and development objectives.").

18 See, e.g., Joost Pauweyln, Rational Design or Accidental Evolution? The Emergence of International Investment Law, in THE FOUNDATIONS OF INTERNATIONAL INVESTMENT LAW 1143 (Zachary Douglas, Joost Pauweyln \& Jorge E. Viñuales eds., 2014) (describing the objective of removing home-state interference in foreign investment disputes as a fundamental driver in the development of the ISDS regime).

19 See, e.g., id.; U.N. Comm'n on Int'l Trade L. (UNCITRAL), Possible Reform of InvestorState Disputes Settlement (ISDS) I 5, U.N. Doc. A/CN.9/WG.III/WP.142 (Sept. 18, 2017) [hereinafter U.N., Possible Reform] ("[T] he ISDS regime was intended to 'de-politicize' investment disputes and effectively remove the risk of such disputes escalating into inter-State conflicts.”). 
discriminatory" measure that "burdens or restricts" U.S. foreign direct investment in that country, among other forms of commerce.20 Upon an affirmative finding, the United States may impose tariffs on that country's exports to the United States. ${ }^{21}$ The United States relied on this authority to find that China's forced technology transfer practices unreasonably burdened or restricted U.S. FDI in China, 22 and then to impose tariffs on over $\$ 500$ billion of Chinese imports into the United States as a countermeasure. ${ }^{23}$ China has retaliated in kind. ${ }^{24}$ In short, the United States used the Section 301 investigation to intervene on behalf of its investors and politicize an investment dispute-the precise type of outcome ISDS was designed to avoid.

An IIA between the United States and China might have avoided that outcome, because investor-state disputes initiated under that IIA would have involved the application of international law to which China had bound itself, and because the remedy for China's breach of the treaty would have been damages paid to aggrieved U.S. investors, 25 not tariffs on Chinese exports to the United States. Indeed, before USTR launched the Section 301 investigation, the United States and China were negotiating an IIA that might have allowed U.S. companies to bring ISDS claims against $\mathrm{China}^{26}$ for the same types of forced technology measures that grounded the Section 301

2019 U.S.C. $\S 2411(\mathrm{~b})(1),(\mathrm{d})(1)(\mathrm{B})$.

21 Id. $\S 2411(\mathrm{c})(1)$.

22 OFF. OFTHE U.S. TRADE REPRESENTATIVE, FINDINGS OFTHE INVESTIGATION INTO CHINA'S ACTS, POLICIES, AND PRACTICES RELATED TO TECHNOLOGY TRANSFER, INTELLECTUAL PROPERTY, AND INNOVATION UNDER SECTION 301 OF THE TRADE ACT OF 1974, at 43-47 (2018).

23 China Section 301-Tariff Actions and Exclusion Process, OFF, OF THE U.S. TRADE REPRESENTATIVE, https://ustr.gov/issue-areas/enforcement/section-301-investigations/tariff-actions [https://perma.cc/4PQD-SJZX].

24 See Wayne M. MORRISON, CONG. RSCH. SERV., IF10708, ENFORCING U.S. TRADE LAWS: SECTION 301 AND CHINA, at 1 (2019) (noting that China had increased tariffs on $\$ 110$ billion worth of U.S. imports).

25 See, e.g., 2012 U.S. Model Bilateral Investment Treaty art. 34.1, https://ustr.gov/sites/default/files/BIT\%20text\%2ofor\%20ACIEP\%2oMeeting.pdf [https://perma.cc/ $\left.\mathrm{F}_{4} \mathrm{QE}-\mathrm{FR} 2 \mathrm{P}\right]$ [hereinafter 2012 Model BIT] (“[A] tribunal may award, separately or in combination, only: (a) monetary damages and any applicable interest; and (b) restitution of property, in which case the award shall provide that the respondent may pay monetary damages and any applicable interest in lieu of restitution.”). In practice, investor-state arbitration tribunals almost invariably award damages, not restitution, for breaches of IIAs. See RUDOLF DOLZER \& CHRISTOPH SCHREUER, PRINCIPLES OF INTERNATIONAL INVESTMENT LAW 293-94 (2d ed. 2012) ("In investment arbitration, the remedy nearly always consists of monetary compensation.")

26 LaURen GlOUdeman \& NARgiza SAlidjanova, U.S.-China ECON. \& SEC. REv. COMM'N, POLICY CONSIDERATIONS FOR NEgOtiating A U.S.-CHINA Bilateral INVESTMENT TREATY 21 (2016) ("The U.S.-China BIT will likely contain traditional ISDS mechanisms, enabling Chinese [state-owned enterprises] with investments in the United States to bring arbitration claims directly against the U.S. government .... U.S. entities with investments in China will likewise be able to bring arbitration claims directly against the Chinese government ....”). 
retaliation. ${ }^{27}$ Unlike the Section 301 tariffs, ${ }^{28}$ such an IIA enjoyed widespread support from U.S. companies, ${ }^{29}$ and would not have caused collateral damage to U.S. companies importing from and exporting to China.

From an economic perspective, the primary arguments favoring ISDS include reducing the risk of FDI and dissuading host states from imposing negative externalities on foreign investors. ${ }^{30}$ IIAs reduce the risks of FDI because they lower transaction costs, provide greater predictability in the substantive obligations host countries must honor, deter host governments from imposing arbitrary costs on foreign investors after the foreign investors have incurred substantial sunk costs, and establish an effective remedy-the ISDS mechanism-for addressing treaty breaches. ${ }^{31}$ This risk reduction, in turn, lowers the cost of capital associated with investing in the host country, thereby incentivizing FDI.32 IIAs reduce the risk that host states impose negative externalities on foreign investors because they discipline states against imposing rent-seeking measures on foreign investors-for example, forced technology transfer. ${ }^{33}$ Such substantive obligations, accompanied by the ISDS mechanism, therefore ensure that host states do not discriminate against foreign investors vis-à-vis domestic investors.

Despite these foreign policy and economic arguments in its favor, ISDS has weathered a legitimacy crisis over the past decade. ${ }^{34}$ Some claim that IIAs

27 Compare 2012 U.S. Model BIT, supra note 25, art. 8.1(f) (prohibiting parties to the treaty from requiring an investor "to transfer a particular technology, a production process, or other proprietary knowledge to a person in its territory" (emphasis added)), with OFF. OF THE U.S. TRADE REPRESENTATIVE, supra note 22, at 19 ("China uses inbound foreign ownership restrictions, such as joint venture (JV) requirements and foreign equity limitations, and the administrative licensing and approvals process to require or pressure the transfer of technology." (emphasis added)).

28 See, e.g., Letter from Agric. Transp. Coal. et al. to Donald Trump, President of the U.S. 1 (Mar. 18, 2018), https://www.itic.org/dotAsset/883ba45b-a06a-4b2a-b6ab-5c84c8a4a865.pdf [https:/perma.cc/8GVV$\mathrm{AFR}_{7}$ ] ("The Administration should not respond to unfair Chinese practices and policies by imposing tariffs or other measures that will harm U.S. companies, workers, farmers, ranchers, consumers, and investors.").

29 Letter from Henry M. Paulson, Jr., Chairman, Paulson Inst. \& John Frisbie, President, U.S.China Bus. Council, to Barack Obama, President of the U.S., \& President Xi Jinping, President of China (Sept. 14, 2015), https://www.uschina.org/sites/default/files/Sept\%202015\%20CEO\%2oBIT\%2oletter\% 20to\%20Presidents\%20Obama\%20and\%20Xi\% ${ }_{20} \% 28 \mathrm{ENG} \% 20 \% 2 \mathrm{~B} \% 20 \mathrm{CHI} \% 29$.pdf [https://perma.cc/ G554-UQTF] ("We are pleased to submit to you a letter from the heads of 94 of America's top companies in support of a high-standard US-China bilateral investment treaty.").

30 See Alan O. Sykes, The Economic Structure of International Investment Agreements with Implications for Treaty Interpretation and Design, 113 AM. J. INT'L L. 482, 484-85 (2019) (discussing the "risk reduction' function of IIAs" and how IIAs seek to address the inefficiencies and externalities that host states can impose on foreign investors).

$31 \mathrm{Id}$. at 497-501.

32 See id. at 491.

$33 \mathrm{Id}$. at $485-90$ (explaining that one of the functions of IIAs is to prevent states from inefficiently undervaluing the welfare of foreign firms and discussing ways in which states may impose rent-seeking measures on foreign investors).

34 See, e.g., U.N., Possible Reform, supra note 19, ๆ 20-47 (noting widespread criticism of ISDS relating to process, outcomes, and lack of impartiality). 
incorporating the ISDS mechanism have not achieved their objective of promoting increased FDI 35 (although the majority of the literature seems to find that IIAs do promote FDI to some extent ${ }^{36}$ ). Other critics contend that ISDS enables investors to invalidate regulatory measures, ${ }^{37}$ gives foreign investors rights that domestic investors lack, ${ }^{38}$ and provides large multinational corporations with the upper hand over host-country governments. ${ }^{39}$

In fact, it seems that the ISDS legitimacy crisis has arisen primarily because, in the past two decades, developed countries have increasingly found themselves as respondents to investor-state claims. For example, the North American Free Trade Agreement (NAFTA) ${ }^{40}$ concluded in 1994, was one of the first IIAs involving two developed countries, the United States and Canada. ${ }^{41}$ Following NAFTA's entry into force, the United States and Canada found themselves as respondents to investor-state claims for the first time. 42

35 See, e.g., Lise Johnson, Brooke Skartvedt Güven \& Jesse Coleman, Investor-State Dispute Settlement: What Are We Trying to Achieve? Does ISDS Get Us There?, COLUM. CTR. ON SUSTAINABLE DEV. (Dec. 11, 2017), http://ccsi.columbia.edu/2017/12/11/investor-state-dispute-settlement-what-are-wetrying-to-achieve-does-isds-get-us-there [https://perma.cc/434H-7 $\left.\mathrm{HX}_{4}\right]$ ("[E]vidence that investment treaties are actually effective at increasing investment flows is inconclusive, and indicates that for the vast majority of investors, IIAs are neither directly nor indirectly determinative of FDI decisions.").

36 See, e.g., U.S.-Mex.-Can. Trade Agreement: Likely Impact on the U.S. Econ. \& on Specific Indus. Sectors 199, Inv. No. TPA 105-003, USITC Pub. 4889 (Apr. 2019) [hereinafter USITC Report] ("The literature generally finds that bilateral investment treaties (BITs), of which ISDS provisions form a crucial part, increase investment, though a substantial minority of papers find no effect."); cf. Sarah Hebous, Priyanka Kher \& Trang Thu Tran, Regulatory Risk and FDI, in GLOBAL INVESTMENT COMPETITIVENESS REPORT 2019/2020, at 128, 128, 135 (World Bank Grp. 2020) (explaining that the World Bank's analysis of a data set comprising "14,000 parent companies investing in nearly 28,000 FDI greenfield and expansion projects across 168 host countries" established that "investor confidence and FDI flows increase with regulatory transparency, investment protection, and effective recourse" to dispute settlement, including ISDS).

37 Cf. BG Grp., PLC v. Republic of Arg., 572 U.S. 25, 58 (2014) (Roberts, C.J., dissenting) ("Substantively, by acquiescing to arbitration, a state permits private adjudicators to review its public policies and effectively annul the authoritative acts of its legislature, executive, and judiciary.").

38 See, e.g., Letter from Columbia Ctr. on Sustainable Inv. to U.S. Dep't of State Advisory Comm. on Priv. Int'l L. 2-3 (May 23, 2019), https://scholarship.law.columbia.edu/cgi/viewcontent.cgi?article= 1040\&context=sustainable_investment_staffpubs [https://perma.cc/7GAT-6F4R] (claiming that U.S. IIAs could afford foreign investors greater substantive rights than U.S. law affords domestic investors in the United States).

39 See Elizabeth Warren, The Trans-Pacific Partnership Clause Everyone Should Oppose, WASH. POST (Feb. 25, 2015), https://www.washingtonpost.com/opinions/kill-the-dispute-settlementlanguage-in-the-trans-pacific-partnership/2015/02/25/ec7705a2-bdie-11e4-b274-

e5209a3bc9a9_story.html [https://perma.cc/NW67-8N6S] ("[P]rogressives should oppose ISDS because it would allow big multinationals to weaken labor and environmental rules.").

40 North American Free Trade Agreement, Dec. 17, 1992, Can.-Mex.-U.S., 32 I.L.M. 289 [hereinafter NAFTA].

41 Patrick Dumberry, The Fair and Equitable Treatment Standard: A Guide to NAFTA CASE LAW ON ARTICLE $1105 \S 1$ [A] (2013) ("NAFTA Chapter 11 is also a milestone since it is the first investment agreement between two developed countries: Canada and the United States.").

42 See, e.g., Loewen Grp., Inc. v. United States of America, ICSID Case No. ARB(AF)/98/3, Notice of Claim, I 12 (Oct. 30, 1998), https://www.italaw.com/sites/default/files/case- 
More recently, developed countries in Europe have faced their first ISDS disputes as respondents. ${ }^{43}$ For example, Germany, which concluded the world's first IIA with Pakistan in $1959,{ }^{44}$ and which has concluded more IIAs than any other country in the world (136), 45 found itself on the opposing end of two high-profile ISDS claims by Swedish power-generation company Vattenfall in 2009 and 2012. In the first dispute, Vattenfall sued Germany under the Energy Charter Treaty, alleging that, after it began construction of a government-approved coal-fired power plant in Germany, German authorities enacted a series of regulatory measures that arbitrarily delayed the plant's construction and that imposed burdensome restrictions on it. ${ }^{46}$ The case settled in 2010.47 In the second dispute, Vattenfall sued Germany for breaching a prohibition on unlawful expropriation under the Energy Charter Treaty after Germany implemented a measure to phase out nuclear power

documents/italaw9045.pdf [https://perma.cc/338G-SQM8] ("[T]he United States itself directly breached Article 1105 of NAFTA, which imposes affirmative duties on the United States to provide 'full protection and security' ... against third-party misconduct."); S.D. Myers, Inc. v. Gov't of Can., Notice of Arbitration, at 3-4 (NAFTA Arb. Trib. Oct. 30, 1998), https://www.italaw.com/sites/default/files/case-documents/italaw8490.pdf [https://perma.cc/V8YVTPY8] ("As a result of Canada's actions, the Investor has suffered economic harm to its Investment through interference with its operations, lost contracts and opportunities in Canada. The Investor alleges that the Government of Canada has breached its obligations under Chapter 11 of the NAFTA ...."); DUMBERRY, supra note $41, \S 1[\mathrm{~A}]$ (noting that controversy about investor-state arbitration proceedings arose under NAFTA because, "for the very first time, [those proceedings] involved Canada and the United States as respondent States").

43 See, e.g., Luke Eric Peterson, Germany Faces Energy Charter Treaty Claim by Swedish Corp over Regulatory Squeeze on Coal-Fired Power Plant, INV. ARB. REP. (Apr. 2, 2009), https://www.iareporter.com/articles/germany-faces-energy-charter-treaty-claim-by-swedish-corp-overregulatory-squeeze-on-coal-fired-power-plant [https:/perma.cc/AGG4-3CU8] ("In a rare development, a Western European state is facing an investment treaty arbitration, as Germany stands accused by the Swedish energy company Vattenfall of breaching various protections contained in the Energy Charter Treaty.").

44 See Jeswald W. Salacuse, BIT by BIT: The Growth of Bilateral Investment Treaties and Their Impact on Foreign Investment in Developing Countries, 24 INT'L LAW. 655, 655 (1990) ("West Germany and Pakistan signed the first BIT in 1959.").

45 ANTHONY LUZZATTO GARDNER, STARS WITH STRIPES: THE ESSENTIAL PARTNERSHIP BETWEEN THE EUROPEAN UNION AND THE UNITED STATES 107 (2020).

46 See, e.g., Luke Eric Peterson, German Media Reveal Details of Vattenfall Claim v. Germany; NGOs Raise Enviro Fears as Two Arbitrators Named, INV. ARB. REP. (July 17, 2009), https://www.iareporter.com/articles/german-media-reveal-details-of-vattenfall-claim-v-germanyngos-raise-enviro-fears-as-two-arbitrators-named [https://perma.cc/5AUA-YT $3 \mathrm{~A}$ ] (describing the "politically-motivated delays and onerous new restrictions" that the German government allegedly imposed, which Vattenfall argued breached Germany's obligations under the Energy Charter Treaty).

47 See Parties Announce Settlement of Dispute Over German Power Plant, INV. ARB. REP. (Aug. 28, 2010), https://www.iareporter.com/articles/parties-announce-settlement-of-dispute-over-germanpower-plant [https://perma.cc/8REE-SAJV] ("A Swedish power company and the Federal Republic of Germany have reportedly settled their ICSID arbitration arising out of the stalemated construction of a controversial coal-fired power plant in the city of Hamburg."). 
plants in the wake of the Fukushima disaster. ${ }^{48}$ The measures required Vattenfall to immediately cease the operation of its nuclear reactors in Germany. 49 The second Vattenfall dispute generated significant backlash against ISDS from German civil society groups and government officialsprimarily because of the perception that it would be inequitable to compensate Vattenfall for adverse economic consequences it suffered from Germany's decision to eliminate nuclear-energy use.50 Moreover, the Vattenfall dispute mobilized German opposition to ISDS in T-TIP, ${ }^{51}$ which, among opposition from other quarters in E.U. Member States, led the European Union to pause T-TIP negotiations and develop the Investment Court System as an alternative to traditional ISDS. ${ }^{52}$

Public backlash against ISDS claims like those brought by Vattenfall also energized the European Union's participation in multilateral efforts to reform the international investment law regime. ${ }^{33}$ The most significant discussions have taken place under the auspices of Working Group III of the United Nations Commission on International Trade Law (UNCITRAL), 54 through

48 See Germany Is Sued at ICSID by Swedish Energy Company in Bid for Compensation for Losses Arising Out of Nuclear Phase-Out, INV. ARB. REP. (June 1, 2012), https://www.iareporter.com/articles/germanyis-sued-at-icsid-by-swedish-energy-company-in-bid-for-compensation-for-losses-arising-out-ofnuclear-phase-out [https://perma.cc/5 $\mathrm{F} 8 \mathrm{D}-9 \mathrm{G}_{2} \mathrm{~N}$ ] (reporting that the German government's decision to "renounce[] the use of nuclear power" affected Vattenfall's operations in Germany and that damages in the arbitration could exceed $€ 700$ million). The dispute recently settled, with Germany agreeing to pay Vattenfall an aggregate $€ 1.4$ billion in damages. See Press Release, Vattenfall, Understanding to Terminate Disputes on German Nuclear Phase Out (Mar. 5, 2021), https://group.vattenfall.com/pressand-media/pressreleases/2021/understanding-to-terminate-disputes-on-german-nuclear-phase-out [https://perma.cc/ $33 \mathrm{KW}-58 \mathrm{NH}]$.

49 Alexsia T. Chan \& Beverly K. Crawford, The Puzzle of Public Opposition to TTIP in Germany, 19 BUS. \& POL. 683, 699-700 (2017).

50 See SHAYERAH Ilias AKHTAR, Vivian C. JONES \& RENÉE JOHnSON, CONG. RSCH. Serv., R43387, Transatlantic Trade and InVEstment Partnership (T-TIP) NEGOTIATIONS 39 (2016) ("A flashpoint in EU public debates has been certain high-profile ISDS cases, such as the investment treaty claim filed by Vattenfall, a Swedish energy company, against Germany after the latter initiated a phase-out of its nuclear power program.").

51 Chan \& Crawford, supra note 49, at 686.

52 This pivot in E.U. international investment policy is discussed in detail in infra Section I.B.

53 See AKHTAR ET AL., supra note 50, at 41 (explaining that the European Commission released its Investment Court System proposal following the public backlash about ISDS arising from disputes such as Vattenfall's second investor-state dispute with Germany).

54 The U.N. Commission on International Trade Law (UNCITRAL) is the main UN entity responsible for international trade issues. About UNCITRAL, UNITED NATIONS COMM'N ON INT'L TRADE L., https://uncitral.un.org/en/about [https://perma.cc/RY5D-S8D3]. Different working groups, organized by subject matter, "undertake the substantive preparatory work on topics on UNCITRAL's" work agenda. Working Documents, UNITED NATIONS COMM'N ON INT'L TRADE L., https://uncitral.un.org/en/gateway [https://perma.cc/MXW5-3BMF]. In July 2017, UNCITRAL provided its Working Group III with a mandate to explore options for the reform of investor-state dispute settlement. United Nations Comm'n on Int'l Trade L., Rep. on the Work of Its Fiftieth Session, U.N. Doc. A/72/17, ๆ $263-64$ (2017). Since then, UNCITRAL Member States, under the aegis of Working Group III, have submitted a variety of proposals for ISDS reform, covering a range of 
which Member States have offered a variety of multilateral ISDS reform proposals. ${ }^{55}$ One camp of governments, led by the European Union and its Member States, has advocated for systemic reform of the ISDS regime, including the establishment of a Multilateral Investment Court. ${ }^{56}$ Another bloc, which includes Chile, Japan, Israel, and the United States, has eschewed the Multilateral Investment Court option and focused on incremental reforms-such as increasing transparency in ISDS, guaranteeing the independence and impartiality of arbitrators, and drawing on state-managed instruments to ensure the legal correctness of treaty interpretation. ${ }^{57} \mathrm{~A}$ third, smaller cohort, which includes Brazil and South Africa, has advocated abolishing ISDS altogether. ${ }^{58}$ These competing visions embody the crossroads at which international investment law finds itself.

Having set out the broad contours of the legitimacy crisis facing the ISDS regime, this Part turns to the specific ISDS experiences of the European Union and the United States. It outlines the particular ISDS challenges each has grappled with, as well as the legal and policy responses that each has developed

procedural and substantive issues. See Working Group III: Investor-State Dispute Settlement Reform, UNITED NATIONS COMM'N ON INT'L TRADE L., https://uncitral.un.org/en/working_groups/3/investor-state [https://perma.cc/V26L-EPMQ] (listing draft working papers and recent proposal submissions).

55 See e.g., U.N., Possible Reform, supra note 19, I 20 (noting that concerns about procedural and substantive issues in ISDS "have been said to undermine the legitimacy of the ISDS regime and its democratic accountability").

56 See European Union and Its Member States, Possible Reform of Investor-State Dispute Settlement (ISDS), U.N. Doc. A/CN.9/WG.III/WP.159, ๆ 1 (Jan. 24, 2019) [hereinafter European Union, Possible Reform] (setting forth the "views of the European Union (EU) and its Member States on the possible establishment of a standing mechanism for the settlement of international investment disputes").

57 See, e.g., Gov'ts of Chile, Isr. \& Japan, Proposal for Workplan of Working Group III Submitted by the Delegations of Chile, Israel and Japan, U.N. Doc. A/CN.9/WG.III/WP.163, annex $\mathrm{C}(2)$ (i)-(ii) (Mar. 15, 2019) (advocating for the Working Group to address concerns about ISDS in two stages: first compiling potential solutions - not including the adoption of a multilateral court system - and second determining appropriate methods for adopting potential solutions); Luke Eric Peterson, UNCITRAL Meetings on ISDS Reform Get Off to Bumpy Start, as Delegations Can't Come to Consensus on Who Should Chair Sensitive Process-Entailing a Rare Vote, INV. ARB. REP. (Dec. 9, 2019), https:/www.iareporter.com/articles/uncitral-meetings-on-isds-reform-gets-off-to-bumpy-start-asdelegations-cant-come-to-consensus-on-who-should-chair-sensitive-process-entailing-a-rare-vote [https://perma.cc/UMM 5-2G8W] (comparing the European Union, which "angl[ed] for substantial reforms of the ISDS system," with governments like those of the United States and Japan, which "express[ed] great wariness about the need for dramatic change").

58 See Gov't of Braz., Possible Reform of Investor-State Dispute Settlement, ๆ 1 1-15, U.N. Doc. A/CN.9/WG.III/WP.171 (June 11, 2019) (advocating for an investment facilitation and cooperation model instead of ISDS); Gov't of S. Afr., Possible Reform of Investor-State Dispute Settlement (ISDS), ๆ 18, U.N. DOC. A/CN.9/WG.III/WP.176 (July 17, 2019) ("[T] here is need for an alternative to ISDS in the form of a more modern and structured dispute settlement processone that is better adapted to investment disputes that involve sustainable development, public policy issues and a range of different stakeholders and interests.") 
to address those challenges. These legal and policy responses frame the boundaries of - and opportunity for-a successful E.U.-U.S. IIA negotiation.

\section{B. The E.U. Experience with Investor-State Dispute Settlement}

The European Union has taken a winding path to arrive at its current position on ISDS. Each step on that path is essential for understanding the European Union's current commitment to an ISDS model that replaces traditional, ad hoc arbitration with an Investment Court System. To explain that path, this Section first examines the European Union's response to a pronounced public backlash against traditional ISDS during the T-TIP negotiations: the development of the Investment Court System. Second, it explains the European Court of Justice's (CJEU) opinion clarifying that the European Union and its Member States share competence over the adoption of ISDS mechanisms in E.U. IIAs, complicating the negotiation of IIAs with an ISDS mechanism.

Third, it discusses the doubt cast on the European Union's competence to include any type of ISDS mechanism in its IIAs by the CJEU's defiant 2018 Achmea opinion, which declared all IIAs between E.U. Member States invalid on the ground that they contravened E.U. law. Fourth, this Section analyzes how the CJEU's Opinion 1/17, issued shortly after the Achmea opinion, saved the European Union's competence to negotiate ISDS provisions in its IIAs with non-E.U. Member States but effectively locked the European Union into a negotiating position that requires some form of appellate mechanism in its IIAs.

1. The European Union's Evolving ISDS Policy from 2010 to 2015

The European Commission's pivot in its negotiating position on ISDS during the 2013 T-TIP negotiations formed the political backdrop for the CJEU's ISDS-related decisions. ${ }^{99}$ Since the European Union acquired the competence to regulate FDI and international trade in the Lisbon Treaty in $2009,{ }^{60}$ it has wrestled with legitimacy challenges to ISDS. The Lisbon Treaty amended the European Union's foundational treaties-the Treaty on

59 The European Commission leads trade and investment agreement negotiations with trading partners. JANA TITIEVSKAIA, EUROPEAN PARLIAMENTARY RSCH. SERV., PE 642.229, EU TRADE POLICY 16 (2019), https://www.europarl.europa.eu/RegData/etudes/IDAN/2019/642229/EPRS_IDA(2019)642229 EN.pdf [https://perma.cc/7WBX-TTX 3 .

60 See Consolidated Version of the Treaty on the Functioning of the European Union arts. 20607, May 9, 2008, 2008 O.J. (C115) 47 [hereinafter TFEU] (stating that the European Union "shall contribute, in the common interest, to the harmonious development of world trade, [and] the progressive abolition of restrictions on international trade and on foreign direct investment" through a "common commercial policy"); JOHANN ROBERT BASEDOW, THE EU IN THE GLOBAL INVESTMENT REGIME § 3.1.2 (2017) ("Since the entry into force of the Lisbon Treaty in 2009, the regulation of FDI [came] under the scope of the [Common Commercial Policy] and exclusive [European] Union competence."). 
European Union (TEU) and the Treaty Establishing the European Community-with the latter renamed the Treaty on the Functioning of the European Union (TFEU). ${ }^{61}$ The scope of the Lisbon Treaty was broad: to clarify the European Union's competencies, its relationship with Member States, and its institutional mechanics. ${ }^{62}$ As is relevant for this Comment, Part Five of the TFEU addresses the European Union's competence vis-à-vis "External Action."63 Article 207, located in Title II ("Common Commercial Policy") of Part Five, equips the European Union with the power to negotiate international agreements covering trade and FDI. 64

After acquiring that power, the European Union initially supported the inclusion of traditional ISDS provisions in its IIAs. ${ }^{65}$ Indeed, when it launched T-TIP negotiations with the United States in 2013, the European Union's negotiating objectives included securing an investment chapter with strong investor protections and an ISDS mechanism, provided that the chapter struck a proper balance between investment protection and the right to regulate.66 It soon became clear, however, that the European Parliament, which effectively wielded a veto over IIAs that the European Commission negotiated, would not approve an E.U.-U.S. IIA with the traditional ISDS mechanism. ${ }^{67}$

In January 2014, under pressure from environmental and consumer groups who contended that ISDS would favor American corporations and undermine

61 Eeva Pavy, Eur. Parliament, The Treaty of Lisbon 1 (2020), https://www.europarl.europa.eu/ftu/pdf/en/FTU_1.1.5.pdf [https://perma.cc/GWQ5-CE2F] ("The Treaty establishing the European Community is renamed the 'Treaty on the Functioning of the European Union' and the term 'Community' is replaced by 'Union' throughout the text.").

$62 \mathrm{See} i d$. at 2 (explaining that "[ $\mathrm{t}]$ he Treaty of Lisbon for the first time clarifies the powers of the Union," including when the European Union and Member States share competencies, and "for the first time provides for a formal procedure to be followed by Member States wishing to withdraw from the European Union").

63 TFEU, supra note 6o, pt. 5 .

64 Id. pt. 5, tit. II, art. 207.

65 See European Commission Memorandum MEMO/13/95, European Union and United States to Launch Negotiations for a Transatlantic Trade and Investment Partnership 2 (Feb. 13, 2013) ("The aim is to achieve the highest levels of liberalisation and investment protection that both sides have negotiated to date in other trade deals.").

66 See Council Directive 11103/13, If 22-23 (Oct. 9, 2014), https://data.consilium.europa.eu /doc/document/ST-11103-2013-DCL-1/en/pdf [https://perma.cc/FJR2-2PXW] (explaining that the objectives of an E.U.-U.S. agreement should include "the highest standards of protection" that is "without prejudice to the right of the EU and the Member States to adopt and enforce ... measures necessary to pursue legitimate public policy objectives").

67 See Resolution of 8 July 2015 Containing the European Parliament's Recommendations to the European Commission on the Negotiations for the Transatlantic Trade and Investment Partnership (TTIP), ๆ $\mathrm{S}(2), \mathrm{S}(2)(\mathrm{d})(\mathrm{xv})$, 2017 O.J. (C 265) 35, 39, 46 (recommending that the Commission "replace the ISDS system with a new system for resolving disputes"). 
E.U. Member State sovereignty, 68 the European Commission halted T-TIP investment chapter negotiations so that it could hold public consultations on the inclusion of an ISDS mechanism in T-TIP. ${ }^{69}$ Between March and July of 2014, the Commission invited online comments on investment protection and ISDS in T-TIP.70 Although the consultations generated roughly 195,000 submissions, $97 \%$ were submitted using pre-populated answer forms created on various online platforms, many of which opposed the inclusion of ISDS in T-TIP.71 The more substantive comments came from roughly 3,000 E.U. citizens and 450 organizations (representing business and civil society) and reflected varied positions on the role of ISDS in T-TIP.72

In May 2015, after consulting other stakeholders in the European Union, the Commission released a concept paper in which it proposed replacing the traditional ISDS mechanism with a two-tiered Investment Court System, including an appellate mechanism.73 According to the concept paper, the Investment Court System would lay the groundwork for a permanent Multilateral Investment Court. 74 The European Parliament, whose members are elected by E.U. Member State citizens,75 approved this proposed compromise on July 8, 2015.76 In short, the European Commission had

68 EU Freezes Part of Transatlantic Trade Negotiations with US, DEUTSCHE WELLE (Jan. 21, 2014), https://www.dw.com/en/eu-freezes-part-of-transatlantic-trade-negotiations-with-us/a-173 76907 [https://perma.cc/MB54-EURJ].

69 European Commission Press Release IP/14/56, Commission to Consult European Public on Provisions in EU-US Trade Deal on Investment and Investor-State Dispute Settlement (Jan. 21, 2014) (announcing the E.U. Trade Commissioner's decision to "consult the public on the investment provisions" of T-TIP following "unprecedented public interest" in the T-TIP negotiations).

70 Online Public Consultation on Investment Protection and Investor-to-State Dispute Settlement (ISDS) in the Transatlantic Trade and Investment Partnership Agreement, at 2-3, 8 SWD 3 final (Jan. 13, 2015).

71 See id. at 3, 10 (stating that approximately 145,000 of 150,000 replies were submitted by nongovernmental organizations that provided pre-prepared answers that respondents adhered to and that about 50,000 of these responses contained general statements opposing T-TIP).

72 See $i d$. at 11 (noting that the consultation database recorded 3,144 individual replies from citizens of the European Union and 445 individual replies from organizations such as "NGOs, academics, individual companies, trade union organisations, consumer protection groups, business association[s] and so on"); see also id. at 3-4 (identifying various concerns raised by public comments, including concerns about protecting Member States' right to regulate, the functioning of tribunals, the appellate mechanism, and how ISDS would interact with domestic judicial systems).

73 Eur. COMM'N, INVESTMENT IN TTIP AND BEYOND-THE PATH FOR REFORM 11, https://trade.ec.europa.eu/doclib/docs/2015/may/tradoc_153408.PDF [https://perma.cc/5M6P-K5CR].

74 See id. at 11-12 ("Therefore, the EU should pursue the creation of one permanent court. . . . The objective would be to multilateralise the court either as a self-standing international body or by embedding it into an existing multilateral organization.").

75 Welcome to the European Parliament, EUR. PARLIAMENT, https://www.europarl.europa.eu/aboutparliament/en [https://perma.cc/R25J-ET2 $\mathrm{P}$ ] ("The Members of the European Parliament are directly elected by voters in all Member States to represent people's interests with regard to EU law-making and to make sure other EU institutions are working democratically.").

76 European Parliament Press Release, 20150702IPR73645, TTIP: Ease Access to US Market, Protect EU Standards, Reform Dispute Settlement (July 8, 2015) https://www.europarl 
developed an ISDS mechanism that enjoyed more legitimacy in the eyes of the E.U. Member States than traditional, ad hoc arbitration.

\section{Opinion $2 / 15$}

Against this political backdrop, on May 16, 2017, the CJEU issued Opinion $2 / 15$, which determined the provisions of the E.U.-Singapore FTA that fell under the exclusive competence of the European Union, the shared competence of the European Union and its Member States, and the exclusive competence of the Member States. 77 The decision clarified that while Article 207 of the TFEU gives the European Union exclusive competence over FDI, regulation over portfolio investment and the ISDS mechanism are matters of shared competence between the European Union and its Member States.78 Thus, E.U. FTAs that regulate portfolio investment or that provide for some form of ISDS, such as the E.U.Singapore FTA, must be ratified by each E.U. Member State. ${ }^{79}$

For the time being, then, the Investment Court System that the European Union had introduced into the E.U.-Singapore FTA and the Comprehensive Economic and Trade Agreement (CETA) with Canada could proceed, provided that Member States unanimously ratified those agreements' provisions on the ISDS mechanism. But the decision did not resolve the thornier issue of whether ISDS itself-included in traditional, ad hoc form or within an Investment Court System-complied with E.U. law.80 The resolution of that fundamental question would wait until Belgium posed the question directly to the CJEU in Opinion 1/17.

\footnotetext{
.europa.eu/pdfs/news/expert/2015/7/press_release/20150702IPR73645/20150702IPR73645_en.pdf [https://perma.cc/GDQ9-SZR ] (explaining that the European Parliament approved a recommendation to the European Commission that the European Union should include an investment court system with an appellate mechanism in T-TIP).

77 Op. 2/15 of the Ct., ECLI:EU:C:2017:376, \ 1 (May 16, 2017).

$78 \mathrm{Id}$. शा 226-43. The CJEU concluded that "the European Union does not have exclusive competence to conclude an international agreement with the Republic of Singapore in so far as it relates to the protection of non-direct foreign investments." Id. \ 238. But, the CJEU continued, "the commitments contained in Section A of Chapter 9 of the envisaged agreement fall within the common commercial policy of the European Union and, therefore, within the latter's exclusive competence." Id. ๆ 243.

79 Id. Iा 292-93 ("Such a regime, which removes disputes from the jurisdiction of the courts of the Member States, cannot be of a purely ancillary nature within the meaning of the case-law recalled in paragraph 276 of this opinion and cannot, therefore, be established without the Member States' consent.").

80 See, e.g., George A. Bermann, European Union Law and International Arbitration at a Crossroads, 42 FORDHAM INT'L L.J. 967, 976 (2019) ("The question whether EU law autonomy bars an international court or tribunal from interpreting and applying EU law will take center stage in what is to be the CJEU's Opinion $1 / 17$ on the compatibility with EU law of the [CETA].").
} 


\section{Achmea}

Before releasing Opinion 1/17, however, the CJEU issued the seminal Achmea decision, which induced further handwringing among those hoping to see the European Union's Investment Court System-let alone any type of ISDS mechanism-endure as a feature of E.U. IIAs. ${ }^{81}$ In Achmea, the CJEU considered whether IIAs concluded between E.U. Member States contravened E.U. law. 82

In the underlying dispute, the Dutch insurance company Achmea sued Slovakia under the Netherlands-Slovakia BIT, contending that Slovakia had breached its treaty obligations to provide fair and equitable treatment (FET) and to avoid indirect expropriation without prompt and effective compensation. 83 In an UNCITRAL-based arbitration registered at the Permanent Court of Arbitration and seated in Germany, Slovakia contended that the Netherlands-Slovakia BIT's ISDS provision contravened E.U. law and was therefore void, depriving the tribunal of jurisdiction. ${ }^{84}$ The tribunal rejected Slovakia's argument and awarded damages to Achmea at the merits stage of the arbitration. 85

Slovakia then sought to have the award reversed in the Higher Regional Court of Frankfurt am Main, and then on appeal before the German Federal Court of Justice, on the basis that the award was null and void and contrary to public policy. ${ }^{86}$ Slovakia argued that the tribunal erred by determining for itself that Article 8 of the Netherlands-Slovakia BIT was compatible with E.U. law, because Articles 267 and 344 of the TFEU provide that the CJEU has exclusive jurisdiction to provide preliminary rulings on the interpretation of E.U. law, and because Member States must submit disputes concerning interpretation or application of E.U. law via the TFEU's preliminary reference procedure. 87 Because these alleged conflicts between the BIT and Articles 267 and 344 of the TFEU were issues of first impression, the German

81 See, e.g., Carola Glinski, Achmea and Its Implications for Investor Dispute Settlement 19-21 (Univ. of Copenhagen Fac. of L. Legal Stud. Rsch. Paper, Working Paper No. 2019-70) (2019), https://papers.ssrn.com/sol3/papers.cfm?abstract_id=3291279 ("[I]t remains to be seen how far the decisive considerations of the Achmea ruling, namely the autonomy of EU law and the principle of loyalty, also extend to an extra-EU context and whether the safeguards enshrined in CETA might be regarded as sufficient.").

82 Case C-284/16, Slowakische Republik (Slovak Republic) v. Achmea BV, ECLI:EU:C:2018:158, ๆ 1-2 (Mar. 6, 2018). This case concerned a BIT between the Kingdom of the Netherlands and Slovakia, both E.U. Member States. Id. ๆ 7 .

$83 \mathrm{Id}$. ๆ $3,8-9$.

$84 \mathrm{Id}$. ๆ $\uparrow 10-12$.

85 Id. ๆ 12.

$86 \mathrm{Id}$. ๆโ $5,12$.

87 Id. I 14; see also TFEU, supra note 60, art. 267 (defining the scope of the CJEU's jurisdiction over preliminary rulings); id. art. 344 (barring E.U. Member States from submitting questions requiring the interpretation or application of E.U. law to courts or tribunals besides those authorized to interpret and apply E.U. law under the TFEU). 
Federal Court of Justice referred the question of compatibility of intra-E.U. BIT ISDS mechanisms with E.U. law to the CJEU. 88

Before the CJEU issued its ruling, its Advocate General 89 concluded in a thorough, forty-eight page opinion that the ISDS mechanism in the Netherlands-Slovakia BIT did not breach Articles 267 or 344 of the TFEU.90 First, the Advocate General contended that arbitration tribunals contemplated by Article 8 of the BIT qualified as "courts or tribunals" within the meaning of Article 267 of the TFEU and the case law interpreting it: the tribunals were established by law, were supported by permanent arbitral institutions, commanded compulsory jurisdiction, applied "rules of law," and provided independent and impartial adjudication..$^{91}$ Second, he reasoned that Article 344 of the TFEU does not bar intra-E.U. BITs-such as the one between the Netherlands and Slovakia-because the arbitral tribunals established by intra-E.U. BITs are "courts or tribunals" within the meaning of Article 267 of the TFEU, disputes between investors and states arising out of those BITs do not fall within the scope of Article 344 of the TFEU, and those BITs do not alter the allocation of power fixed by the E.U. treaties. ${ }^{92}$

In a mere eleven-page opinion, however, the CJEU held instead that the intra-E.U. BIT contravened E.U. law. It reasoned that the dispute resolution clause in the Netherlands-Slovakia BIT required tribunals to "interpret or indeed to apply E.U. law" within the meaning of Article 344 of the TFEUeven though, according to the CJEU, arbitral tribunals are not "courts or tribunals" within the meaning of Article 267 of the TFEU.93 The Court further reasoned that, although awards issued by tribunals contemplated by the Netherlands-Slovakia BIT could be subject to annulment proceedings in courts that were part of the preliminary reference system-as the German Federal Court of Justice was in this case-the BIT's annulment mechanism still did not properly bring the tribunals issuing such awards within the scope of the preliminary reference system. ${ }^{94}$

Finally, the Court held that the ISDS mechanism in the NetherlandsSlovakia BIT undermined the principle of mutual and sincere cooperation

88 Case C-284/16, Op. of Advoc. Gen., ECLI:EU:C:2017:699, ๆ \ 2, 29-30 (Sept. 19, 2017).

89 See id. The Advocate General issues advisory opinions to the CJEU on how the court should resolve the issues presented in the disputes pending before it. See RAFAŁ MAŃKO, EUR. PARLIAMENTARY RSCH. SERV., PE 642.237, ROLE OF ADVOCATES GENERAL AT THE CJEU 5 (2019) (noting that although these opinions are "merely advisory," the CJEU usually references them).

90 Case C-284/16, Op. of Advoc. Gen., II 273.

91 Id. ๆ ๆ 90-119.

92 Id. $\uparrow$ T $153^{-272 .}$

93 Case C-284/16, Slowakische Republik (Slovak Republic) v. Achmea BV, ECLI:EU:C:2018:158, ๆ ๆ 39-49 (Mar. 6, 2018).

$94 \mathrm{Id}$. ๆ $52-55$. 
enshrined in Article 4(3) of the TEU,95 because the BIT applied between two E.U. Member States and undermined the autonomy of the E.U. order as established by Article 344 of the TFEU. ${ }^{96}$ In this respect-and against the background of the Investment Court System the European Commission had recently proposed for its pending FTAs with non-E.U. Member States-the CJEU distinguished arbitral tribunals established under intra-E.U. BITs from those established under treaties between the European Union and nonE.U. Member States. ${ }^{97}$ The CJEU concluded that the European Union maintained the competence to conclude international agreements that contained arbitration mechanisms with non-E.U. countries, "provided that the autonomy of the E.U. and its legal order is respected."98

The Achmea decision reverberated through the international arbitration community and raised several important questions. Those questions included how exactly E.U. Member States would go about terminating the 196 intraE.U. BITs in force, as well as the effect that the judgment would have on Member State commitments to each other vis-à-vis the Energy Charter Treaty,99 a multilateral IIA to which multiple E.U. Member States, and the European Union itself, are parties. ${ }^{100}$

More important for the purpose of this Comment, however, was the CJEU's qualifier in Achmea that international agreements between the European Union and non-E.U. countries containing extra-E.U. settlement mechanisms could comply with E.U. law only if "the autonomy of the E.U. and its legal order [was] respected."101 Did the Investment Court System that now served as the centerpiece of the European Union's ISDS negotiating position in its FTAs with the United States, Canada, and Singapore undermine the autonomy of the European Union and its legal order?102

95 Article 4(3) of the TEU provides, in relevant part, that "[p]ursuant to the principle of sincere cooperation, the Union and the Member States shall, in full mutual respect, assist each other in carrying out tasks which flow from the Treaties." Consolidated Version of the Treaty on European Union, art. 4(3), Oct. 26, 2012, 2012 O.J. (C 326$) 18$.

$96 \mathrm{Id}$. ๆ $57-60$.

$97 \mathrm{Id}$. I 57.

$98 \mathrm{Id}$.

99 Energy Charter Treaty, Dec. 17, 1994, 2080 U.N.T.S. 95.

100 On May 5, 2020, twenty-three E.U. Member States signed a treaty terminating intra-E.U. BITs, which was designed to implement the Achmea judgment. Agreement for the Termination of Bilateral Investment Treaties between the Member States of the European Union, May 5, 2020, 2020 O.J. (L 169) 1, pmbl., arts. 2-4, annex A.

101 Case C-284/16, Slowakische Republik (Slovak Republic) v. Achmea BV, ECLI:EU:C:2018:158, \ 57 (Mar. 6, 2018).

102 Cf. Bermann, supra note 8o, at 978 (considering whether the CJEU would hold that CETA's Investment Court System, as established under the treaty, respected the European Union's autonomy and legal order, and arguing that "[o]ne can only hope that EU law public policy will not get in the way of the authority of CETA tribunals ... to perform substantive review of EU law measures"). 


\section{CETA and Opinion 1/17}

A year and a half after Achmea, the CJEU answered that question in Opinion 1/17. Underlying this opinion was the ratification of CETA's Investment Court System. Under Opinion 2/15, every E.U. Member State needed to ratify CETA's Investment Court System for it to become effective. ${ }^{103}$ Thus, the ratification of CETA ground to a halt as Wallonia, which has one of Belgium's five sub-federal parliaments, ${ }^{104}$ threatened to block Belgium's approval of the Investment Court System. ${ }^{105}$ To secure Wallonia's support for CETA, Belgium referred the question of the compatibility of CETA's Investment Court System with E.U. law to the CJEU, which resulted in Opinion 1/17.106

Understanding Opinion $1 / 17$ requires understanding the CETA investment chapter's basic elements. This subsection therefore explains those elements before examining Opinion 1/17.107

\section{a. Structure and Content of the CETA Investment Chapter}

Like most IIAs, the CETA investment chapter maps onto substantive and procedural categories. Sections A through $\mathrm{E}$ of the chapter address substantive provisions related to the protection of investments. These include

103 See Op. 2/15 of the Ct., ECLI:EU:C:2017:376, ๆ 305 (May 16, 2017) (holding that ISDS provisions, including the Investment Court System, fall within the shared competence of the European Union and its Member States); European Parliament Press Release 20170209IPR61728, CETA: MEPs Back EU-Canada Trade Agreement (Feb. 15, 2017), https://www.europarl.europa.eu/news/en/pressroom/20170209IPR61728/ceta-meps-back-eu-canada-trade-agreement [https:/perma.cc/RH8J-4L7U] ("As CETA was declared a mixed agreement by the European Commission in July 2016, it will also need to be ratified by national and regional parliaments."); see also Jennifer Rankin, Belgian Politicians Drop Opposition to EU-Canada Trade Deal, THE GUARDIAN (Oct. 26, 2016), https://www.theguardian.com/world/2016/oct/27/belgium-reaches-deal-with-wallonia-over-eu-canadatrade-agreement [https://perma.cc/BG9P-6CJD] (noting that CETA "will only become a complete and permanent legal document following ratification by at least 38 national and regional parliaments in Europe").

104 GARDNER, supra note 45, at 110.

105 See id. ("The Walloon parliament persisted with its objections to CETA until the very last moment, nearly killing the deal in the spring of 2016 against the wishes of the remaining $99 \%$ of the EU population.").

106 See Laurens Ankersmit, Investment Court System in CETA to Be Judged by the ECJ, EUR. L. BLOG (Oct. 31, 2016) https://europeanlawblog.eu/2016/10/31/investment-court-system-in-ceta-tobe-judged-by-the-ecj [https://perma.cc/3QDD-R2 FG] ("[T]he Walloon parliament wanted to know whether ICS [Investment Court System] is compatible with the EU Treaties, and asked the Belgian federal government to make use of the procedure of Article 218(11) TFEU to request the CJEU's opinion on the issue.").

107 European Commission, Investment Provisions in the EU-Canada Free TRADE AGREEMENT (CETA) preamble (Feb. 2016) ("CETA confirms all the innovations of the EU's new approach on investment and its dispute settlement mechanism thus meeting the high expectations of citizens and industry for a fairer, more transparent and institutionalised system of settling investment disputes."). 
the commitment by Canada and the European Union not to discriminate against foreign investments on the basis of nationality, ${ }^{108}$ to provide fair and equitable treatment to investors and their investments, 109 and to avoid direct and indirect expropriation without prompt and effective compensation. ${ }^{110}$

Most of these substantive provisions are consistent with those found in most IIAs, although a few stand out. Article 8.9, for example, contains four paragraphs that affirm the parties' regulatory sovereignty,111 including the right to regulate to "achieve legitimate [public] policy objectives." 112 Article 8.10 is notable for attempting to tackle one of the thornier investment protection standards, fair and equitable treatment, by providing a closed set of circumstances that constitute breaches of the FET standard. 113 Indeed, in drafting Article 8.10, Canada and the European Union sought to circumscribe the conditions that could result in a FET breach. ${ }^{114}$ This approach differs from that taken by the United States, and thus presents an opportunity for substantive investment protection harmonization in an E.U.-U.S. FTA. 115

The most relevant features of CETA for the CJEU opinion, however, pertain to dispute settlement-especially the sections and articles responsible for establishing and operating CETA's Investment Court System. Section F of CETA establishes the treaty's Investment Court System.116 Article 8.27 provides for a standing Tribunal, which effectively functions as a trial court of first instance. 117 The Tribunal will comprise fifteen members, five of whom

108 See CETA, supra note 14, art. 8.6.1 ("Each Party shall accord to an investor of the other Party and to a covered investment, treatment no less favourable than the treatment it accords, in like situations to its own investors and to their investments ...."); id. art. 8.7.1 ("Each Party shall accord to an investor of the other Party and to a covered investment, treatment no less favourable than the treatment it accords in like situations, to investors of a third country and to their investments ....").

$109 \mathrm{Id}$. art. 8.10.1 (providing that each party shall provide "fair and equitable treatment and full protection and security" to investors and covered investments).

$110 I d$. art. 8.12.1 (prohibiting parties from nationalizing or expropriating covered investments either directly or indirectly, subject to enumerated exceptions and conditions).

111 See id. art. 8.9.2 ("[T] he mere fact that a Party regulates, including through a modification to its laws, in a manner which negatively affects an investment or interferes with an investor's expectations, including its expectations of profits, does not amount to a breach of an obligation under this Section.").

112 Id. art. 8.9.1.

$113 \mathrm{Id}$. art. 8.10.2.

114 See Joint Interpretive Instrument on the Comprehensive Economic and Trade Agreement (CETA) art. 6(c), Can.-European Union, opened for signature Oct. 27, 2016, 2017 O.J. (L 11) 3 ("CETA includes clearly defined investment protection standards, including on fair and equitable treatment and expropriation and provides clear guidance to dispute resolution Tribunals on how these standards should be applied.").

115 See infra subsection II.B.2.

116 CETA, supra note $14, \S \mathrm{F}$, art. 8.18-.45.

117 Id. art. 8.27; see also art. 8.18.1 ("[A]n investor of a Party may submit to the Tribunal constituted under this Section a claim that the other Party has breached an obligation ...."). 
will be Canadian nationals, five of whom will be E.U. Member State nationals, and five of whom will be third-country nationals.118 In a novel development relative to traditional investor-state arbitration, the CETA Joint Committee, which is co-chaired by the Minister for International Trade of Canada and the European Commission's Trade Commissioner, will choose the Tribunal members. ${ }^{119}$ In other words, unlike in traditional investor-state arbitration, 120 investors will not nominate any Tribunal members. The President of the Tribunal will appoint members of the Tribunal to threemember "divisions" of the Tribunal to hear specific disputes, on a "rotation basis." 21 Each division will include one Canadian national, one E.U. Member State national, and one third-country national.122

CETA Article 8.28 establishes an Appellate Tribunal to hear appeals of Tribunal decisions for "errors in the application or interpretation of applicable law," "manifest errors in the appreciation of facts," and the grounds on which awards may be annulled under the ICSID Convention. ${ }^{123}$ Unlike Article 8.27, Article 8.28 does not impose nationality requirements on the Appellate Tribunal members, although Article 8.28 provides that the CETA Joint Committee will appoint the members of the Appellate Tribunal124 and that "division[s] of the Appellate Tribunal constituted to hear [an] appeal shall consist of three randomly appointed Members of the Appellate Tribunal." 125 The establishment of an appellate mechanism is novel in IIAs126 and forms a cornerstone of the European Commission's mandate for negotiating IIAs. ${ }^{127}$ A final provision that would prove pivotal in the CJEU's Opinion 1/17 is CETA Article 8.31.2, which states:

$118 I d$. art. 8.27.2.

119 Id.

120 See, e.g., ICSID Convention, supra note 5, art. 37(2)(b) (providing that an arbitration tribunal may "consist of three arbitrators, one arbitrator appointed by each party and the third, who shall be the president of the Tribunal, appointed by agreement of the parties").

121 CETA Article 8.27.7 does not clarify the phrase "on a rotation basis," except to note that its purpose is to "ensur[e] that the composition of the divisions is random and unpredictable, while giving equal opportunity to all Members of the Tribunal to serve." CETA, supra note 14, art. 8.27.7.

122 Id. art. 8.27.6.

123 Id. art. 8.28.1; 8.28.2(a)-(c).

124 Id. art. 8.28.3.

$125 \mathrm{Id}$. art. 8.28.5.

126 As discussed in infra subsection I.C.1, some U.S. IIAs have contemplated the establishment of an appeals mechanism, but the United States has never followed through and established an appellate mechanism in any of these IIAs.

127 Eur. Comm'n, NeW InVestment Protection Agreements 4 (2020), https://trade.ec.europa.eu/doclib/docs/2020/july/tradoc_158908.pdf [https://perma.cc/WD 4 C$\mathrm{PUW}_{4}$ ] (explaining that the European Union's recently concluded and prospective IIAs "introduce an appeal system," which is a "revolution in dispute settlement" designed to strengthen the legitimacy of dispute settlement under those IIAs (emphasis omitted)). 
For greater certainty, in determining the consistency of a measure with this Agreement, the Tribunal may consider, as appropriate, the domestic law of the disputing Party as a matter of fact. In doing so, the Tribunal shall follow the prevailing interpretation given to the domestic law by the courts or authorities of that Party and any meaning given to domestic law by the Tribunal shall not be binding upon the courts or the authorities of that Party. ${ }^{128}$

By incorporating this language, the CETA parties seemed to go out of their way to ensure that the CJEU would not find that CETA tribunals were authorized to "interpret or apply" E.U. law within the meaning of Article 267 TFEU-a finding that underpinned the CJEU's holding in Achmea that intraE.U. IIAs were invalid under E.U. law.129 With those provisions of CETA explained, this Comment can turn to consider Opinion 1/17.

\section{b. Opinion $1 / 17$}

In Opinion 1/17, the CJEU confronted whether CETA's Investment Court System complied with E.U. law.130 As noted above, the answer to that question was not straightforward following the CJEU's proviso in Achmea that an ISDS mechanism to which the European Union submitted itself needed to respect the "autonomy of the E.U. and its legal order."131 Indeed, the CJEU highlighted this concern at the outset of its Opinion 1/17 analysis, explaining that CETA "may be compatible with E.U. law only if it has no adverse effect on the autonomy of the E.U. legal order." 132

In concluding that CETA's Investment Court System did not undermine the autonomy of the E.U. legal order, the CJEU relied on the following chain of reasoning. First, it explained that for the CETA Investment Court System to avoid disturbing the autonomy of E.U. law, the Tribunal and Appellate Tribunal would need to be restricted to interpreting and applying E.U. law only insofar as (a) that law was part of CETA, 133 and (b) the interpretation and application of E.U. law did not "prevent[] the EU institutions from operating in accordance with the EU constitutional framework." 134 To conclude that CETA satisfied these conditions, the CJEU leaned on CETA Article 8.31.2-especially its provision that the Tribunal and the Appellate

128 CETA, supra note 14, art. 8.31.2 (emphasis added).

129 See supra subsection I.B.3.

130 Op. 1/17 of the Ct., ECLI:EU:C:2019:341, ๆ 1 (May 30, 2019).

131 Case C-284/16, Slowakische Republik (Slovak Republic) v. Achmea BV, ECLI:EU:C:2018:158, ๆ 57 (Mar. 6, 2018)

132 Op. $1 / 17$, श| 108.

133 Id. $\uparrow 119$ ("[I]t is necessary to be satisfied that ... Section F of Chapter Eight of the CETA does not confer on the envisaged tribunals any power to interpret or apply EU law other than the power to interpret and apply the provisions of that agreement ....").

134 Id. \ा 118. 
Tribunal would treat domestic laws only as "matter[s] of fact." 135 This language convinced the CJEU that the CETA Tribunal and Appellate Tribunal would not interpret or apply E.U. law, except for E.U. law that follows from the CETA Agreement. ${ }^{136}$

Second, the CJEU concluded that CETA did not alter the operation of E.U. institutions vis-à-vis the European Union's constitutional framework and, therefore, did not affect the autonomy of the E.U. legal order. ${ }^{137}$ Here, the CJEU responded to a concern raised by Belgium that the award of a CETA Tribunal division might force the European Union or an E.U. Member State to repeal or amend a measure that caused the breach leading to an award.138 In response, the CJEU explained that CETA's investment protection provisions cannot be interpreted to prevent a party from adopting measures that E.U. members deem necessary "to protect public security or public morals or to maintain public order or to protect human, animal or plant life or health;"139 that Article 8.9.1 affirms the parties' right to regulate to achieve legitimate public policy objectives; and that Article 8.9.2 provides that the mere fact that an investor's expectations are not satisfied by a party's regulations does not constitute a breach of the treaty. 140

In short, then, Opinion $1 / 17$ resolved lingering doubts about the compatibility of the European Union's Investment Court System with E.U. law, emboldening the European Commission to negotiate an Investment Court System in its IIAs and to push for a Multilateral Investment Court. Unfortunately for the European Union, however, it would not find a partner eager to embrace the Investment Court System model in the United States.

\section{The U.S. Experience with Investor-State Dispute Settlement}

Like the E.U. position on ISDS, the U.S. position has shifted in response to ISDS criticisms. Although those criticisms have led the United States to entertain the possibility of an appellate mechanism under the aegis of a multilateral institution, the United States has not embraced an investment court model. As with the European Union's negotiating position,

135 Id. ๆ 130 (quoting CETA, supra note 14, art. 8.31.2).

136 Id. \ 136 ("It follows from the foregoing that Section F of Chapter Eight of the CETA does not confer on the envisaged [CETA] tribunals any jurisdiction to interpret or apply EU law other than that relating to the provisions of that agreement.").

137 Id. \ 161.

138 Id. ๆ $137-50$. Opinion 1/17 explains that, under CETA Article 8.39, CETA tribunals may not nullify contested measures or regulations allegedly breaching the treaty provisions, nor may they impose penalties on parties for having enacted such measures. Id. ๆ 144. Instead, a tribunal may only order that the respondent compensate the claimant for damages suffered because of a breach. Id.

139 Id. I 152 (citing CETA, supra note 14, art. 28.3.2).

140 Id. ๆ 154. 
understanding the bounds of the current U.S. negotiating position on ISDS requires an examination of the U.S. experience with ISDS. This subsection therefore discusses the evolution of U.S. ISDS policy from NAFTA to TTIP. In turn, it explains the U.S. position on ISDS during the contemporaneous T-TIP and Transpacific Partnership (TPP) negotiations, and the subsequent pivot toward ISDS skepticism during the Trump Administration. Finally, it explains why the U.S. criticism of the World Trade Organization's (WTO) Appellate Body is inextricably linked to its negotiating position on ISDS.

\section{From NAFTA to T-TIP}

Although the United States signed its first modern IIA in 1982,141 it did not begin to grapple with criticisms of ISDS until after NAFTA entered into force, when it found itself as the respondent in ISDS disputes for the first time-like many developed European countries more recently.142 An especially controversial issue that emerged during these early disputes was tribunals' interpretation of NAFTA's guarantee that the NAFTA parties provide investors of another NAFTA party with fair and equitable treatment. Specifically, NAFTA Article 1105(1) provides the following: "Each Party shall accord to investments of investors of another Party treatment in accordance with international law, including fair and equitable treatment and full protection and security." 143

The FET standard is nearly ubiquitous in IIAs,144 including the CETA agreement between Canada and the European Union. ${ }^{145}$ Controversy about this standard emerged when some early NAFTA tribunals interpreted Article 1105(1) expansively. For example, the tribunal in Pope E Talbot Inc. v. Canada concluded that Article 1105(1)'s FET standard required host states to accord investors treatment above that required by customary international law. ${ }^{146}$ The Pope E Talbot tribunal acknowledged that Article 1105(1)'s plain language

141 Wayne Sachs, The "New" U.S. Bilateral Investment Treaties, 2 INT'L TAX \& BUS. LAW. 192, 192 (1984) (noting, in 1984, that the United States "recently signed the first four of an anticipated series of bilateral treaties concerning the reciprocal encouragement and protection of investment") (internal quotation marks and citations omitted).

142 DUMBERRY, supra note $41, \S 1[\mathrm{~A}]$.

143 NAFTA, supra note 40, art. 1105(1).

144 See International Investment Agreements Navigator-Mapping of IIA Content, UNCTAD, https://investmentpolicy.unctad.org/international-investment-agreements/iia-mapping [https://perma.cc/832E-T2 2 2] (choose fair and equitable treatment from the Standards of Treatment dropdown; then choose "FET Unqualified" and "FET Qualified"; then enter search).

145 See supra subsection I.B.4.

146 Pope \& Talbot Inc. v. Canada, Award on the Merits of Phase 2, ๆ 110-20 (NAFTA Arb. Trib. Apr. 10, 2001), https://www.italaw.com/sites/default/files/case-documents/ita0678.pdf [https://perma.cc/KDV $\left.2-\mathrm{WD}_{7} \mathrm{~K}\right]$. 
suggested that the FET standard referred to in Article 1105(1) was tied to customary international law. ${ }^{147}$ Nonetheless, the tribunal emphasized that Canada and the United States were parties to other IIAs that treated the FET standard as distinct from customary international law's minimum standard of treatment. ${ }^{148}$ According to the tribunal, because those treaties formed sources of international law within the meaning of Article 38 of the Statute of the International Court of Justice, ${ }^{149}$ the FET standard as described in those IIAs meant that NAFTA's Article 1105(1) FET standard required treatment above the international minimum standard. 150

The NAFTA parties would soon reject the Pope E Talbot tribunal's expansive interpretation of Article 1105(1), as well as similarly expansive interpretations of Article 1105(1) by the tribunals in Metalclad v. Mexico and S.D. Myers v. Canada. ${ }^{151}$ In 2001, Canada, Mexico, and the United States issued a Joint Interpretive Statement clarifying that Article 1105(1) prescribed the minimum standard of treatment under customary international law and that Article 1105(1) did not require the NAFTA countries to accord foreign investors treatment above the minimum standard. 152

In the fifteen years following the clarification of Article 1105(1), the United States took successive measures designed to shore up the perceived legitimacy of U.S. IIAs. The principal instrument the United States used to reshape its policy position on the procedure and substance of IIAs during this period was the U.S. Model BIT.153 The Model BIT, co-drafted by USTR and the U.S.

147 Id. If 110.

148 Id. ๆ Т 110-11.

149 Statute of the International Court of Justice art. $3^{8 .}$

150 Pope Es Talbot Inc., ๆ| 113-18.

151 In Metalclad v. Mexico, the tribunal determined that Mexico breached the FET standard because it did not "ensure a transparent and predictable framework for [the investor's] business planning and investment." Metalclad Corp. v. United Mexican States, ICSID Case No. ARB(AF)/97/1, Award, II 99-101 (Aug. 30, 2000), https:/www.italaw.com/sites/default/files/casedocuments/ita0510.pdf [https://perma.cc/97FZ-CHJP]. In S.D. Myers v. Canada, a majority of the tribunal found that a breach of a separate NAFTA provision, Article 1102 (containing NAFTA's national treatment standard for investments), "essentially establishes a breach of Article 1105 " because, the tribunal reasoned, Article 1105 encompassed a broader scope than Article 1102 did. S.D. Meyers, Inc. v. Canada, Partial Award, था 264-66 (NAFTA Arb. Trib. Nov. 13, 2000), https://www.italaw.com/sites/default/files/case-documents/ita0747.pdf [https://perma.cc/F2 $\mathrm{P}_{3}-\mathrm{AN}_{2}$ J].

152 See Interpretations of Chapter 11, Can.-Mex.-U.S., $\S$ B(2), July 31, 2001, https://20092017.state.gov/documents/organization/38790.pdf [https://perma.cc/ 5 EPS-WL6J] ("The concepts of 'fair and equitable treatment' and 'full protection and security' do not require treatment in addition to or beyond that which is required by the customary international law minimum standard of treatment of aliens."). See generally DUMBERRY, supra note 41, $\S 2.02[\mathrm{~A}]$ (describing the history and challenges of determining the "ordinary meaning" of "fair and equitable" (internal quotation marks omitted)).

153 See AKHTAR \& WEISS, supra note 17, at 8 (noting that by developing model BITs, the United States "clarified the objectives for their investment programs and re-evaluated the balance of rights for investors and other economic and non-economic policy priorities (environment, labor, social welfare, etc.) provided in their future investment agreements"). 
State Department, ${ }^{154}$ provides the default text that the United States uses to negotiate IIAs with other countries. ${ }^{155}$

Although the precise content of the U.S. Model BIT has evolved, its basic structure has remained the same since 2004. ${ }^{156}$ It begins with a preamble providing that reciprocal protection of foreign investors "will stimulate the flow of private capital and the economic development of the Parties." 157 The preamble also provides that the BIT aims to protect investors "in a manner consistent with the protection of health, safety, and the environment, and the promotion of internationally recognized labor rights." 158 Thus, the preamble establishes that the BIT should be interpreted to respect states' measures designed to protect public health, safety, the environment, and labor rights. ${ }^{159}$

Section A of the Model BIT establishes the substantive provisions of the BIT, which include obligations to accord the investors of the treaty counterparty national treatment (i.e., to treat foreign investors no less favorably than domestic investors in like circumstances);160 most-favored nation treatment; 161 and fair and equitable treatment.162 Section A also requires treaty parties to refrain from direct and indirect expropriation, except when the expropriation is executed for a public purpose, is non-discriminatory, and provides prompt, adequate, and effective compensation to the investor subject to the expropriation in accordance with due process of law. ${ }^{163}$

Section B of the Model BIT addresses dispute settlement. It enables covered foreign investors to submit investment disputes with the treaty

154 See id. ("The [U.S. Model BIT program] is jointly administered by the Department of State and the United States Trade Representative (USTR).").

155 See Bilateral Investment Treaties, OFF. OF THE U.S. TRADE REPRESENTATIVE, https://ustr.gov/trade-agreements/bilateral-investment-treaties [https://perma.cc/V2BR-7TWD] (“The United States negotiates BITs on the basis of a model text.").

156 The United States developed its Model BIT in 1981. See AKHTAR \& WEISS, supra note 17, at 8 . Since then, it "has been revised several times, most recently in 2004 and 2012." Id.

1572004 Model BIT, pmbl., https://ustr.gov/sites/default/files/U.S.\%2omodel\%2oBIT.pdf [https://perma.cc/3F9J-4XEV]; 2012 Model BIT, supra note 25, pmbl.

1582004 Model BIT, supra note 157, pmbl.; 2012 Model BIT, supra note 25, pmbl.

159 Under the Vienna Convention on the Law of Treaties, a treaty's text must be interpreted in light of its object and purpose, which includes the treaty's preamble. See Vienna Convention on the Law of Treaties, art. 31(1)-(2), opened for signature May 23, 1969, 1155 U.N.T.S. 331 [hereinafter VCLT]. Although the United States has not ratified the VCLT, it treats the VCLT as codifying customary international law. See B-Mex, LLC v. United Mexican States, ICSID Case No. $\operatorname{Arb}(\mathrm{AF}) / 16 / 3$, Second Submission of the United States of America, I 16 n.26 (Aug. 17, 2018), https://www.state.gov/wp-content/uploads/2019/05/Second-U.S.-1128-Submission.pdf

[https://perma.cc/4NXW-AF6L] ("Although the United States is not a party to the [Vienna Convention on the Law of Treaties], it has recognized since at least 1971 that the Convention is the 'authoritative guide' to treaty law and practice." (citation omitted)).

1602004 Model BIT, supra note 157, art. 3; 2012 Model BIT, supra note 25, art. 3.

1612004 Model BIT, supra note 157, art. 4; 2012 Model BIT, supra note 25, art. 4.

1622004 Model BIT, supra note 157, art. 5; 2012 Model BIT, supra note 25, art. 5.

1632004 Model BIT, supra note 157, art. 6; 2012 Model BIT, supra note 25, art. 6. 
counterparty to arbitration, after the foreign investor and treaty counterparty have sought to resolve their dispute through consultation and negotiation. ${ }^{164}$ It further provides that the foreign investor may elect to have the arbitration governed by the ICSID Rules of Procedure for Arbitration Proceedings or the ICSID Additional Facility Rules, as administered by ICSID, among other institutional rules. ${ }^{165}$ That the U.S. Model BIT is designed to work with ICSID enhances the feasibility of adding an appeals mechanism within ICSID, as discussed in subsection II.B.1.

The 2004 and 2012 versions of the Model BIT also emphasize that the investment protection provisions of the BIT operate without prejudice to states' right to regulate. ${ }^{166}$ The 2004 Model BIT, for example, introduced provisions seeking to balance power between investors and states. ${ }^{167}$ Unlike NAFTA Chapter 11,168 the 2004 Model BIT included articles clarifying that investment protections provided in the BIT could not be construed as circumscribing a treaty party's right to adopt measures regulating the environment ${ }^{169}$ or to enforce labor standards..$^{170}$

Article 28.10 of the 2004 Model BIT also explicitly contemplated the development of a multilateral agreement establishing an appellate body to hear disputes arising out of IIAs. ${ }^{171}$ Article 28.10 further provided that parties to the BIT would seek to enable such an appellate body to review awards of disputes arising under the BIT.172 This provision mirrored a negotiating directive in the Trade Act of 2002 that directed the USTR to negotiate ISDS mechanisms that "provid[ed] for an appellate body or similar mechanism to provide coherence to the interpretations of investment provisions in trade agreements."173

In 2012, USTR and the State Department released the 2012 U.S. Model BIT, which replaced the 2004 U.S. Model BIT.174 The 2012 Model BIT

1642004 Model BIT, supra note 157, arts. 23-24; 2012 Model BIT, supra note 25, arts. 23-24.

1652004 Model BIT supra note 157, art. 24.3; 2012 Model BIT, supra note 25, art. 24(3).

166 See, e.g., 2012 Model BIT, supra note 25, art. 12 (describing the importance of each party's relative environmental regulatory authority and noting that "[n]othing in this Treaty shall be construed to prevent a Party from adopting, maintaining, or enforcing any measure otherwise consistent with this Treaty" to respond to environmental concerns).

167 See, e.g., 2004 Model BIT, supra note 157, art. 13.1 ("[E] ach Party shall strive to ensure that it does not waive or otherwise derogate from, or offer to waive or otherwise derogate from, such laws in a manner that weakens or reduces adherence to the internationally recognized labor rights.").

168 See NAFTA, supra note 40, arts. 1101-39.

1692004 Model BIT, supra note 157, art. 12.2.

170 Id. art. 13.1.

$171 \mathrm{Id}$. art. 28.10 .

172 Id.

173 Trade Act of 2002, Pub. L. No. 107-210, § 2102(a)(3)(G)(iv) 116 Stat. 933, 995.

174 See AKHTAR \& WEISS, supra note 17, at 10 ("Changes in the 2012 U.S. Model BIT were relatively modest, but may prove significant by providing greater recognition of labor and environmental issues ...."). The 2012 Model BIT also reflected the work of a three-year study undertaken by the Department of State's Advisory Committee on International Economic Policy 
enhanced the U.S. commitment to protecting fundamental public policy objectives in its IIAs. For example, Article 12 of the 2012 Model BIT, entitled "Investment and Environment," provides an expansive carveout of environmental measures from the reach of investment protection provisions, while Article 13, entitled "Investment and Labor," binds the parties to respect a comprehensive set of labor rights. ${ }^{175}$ On dispute settlement, the 2012 Model BIT, like the 2004 Model BIT, entertains the possibility of an appellate mechanism, albeit in more guarded terms than in the 2004 Model BIT. ${ }^{176}$

\section{T-TIP Round One}

The foregoing legitimacy-enhancing measures, culminating in the 2012 Model BIT, seemed to bode well for an investment chapter in T-TIP, which the European Union and the United States began negotiating in July 2013. ${ }^{177}$ The European Union and the United Sates aimed to make T-TIP a comprehensive FTA, meaning that the treaty would address market access barriers across a range of sectors, regulatory cooperation and harmonization, and investment protection. ${ }^{178}$ The U.S. emphasis on safeguarding regulatory space in IIAs, in particular, aligned with the European Union's negotiating position leading into the T-TIP negotiations.179 Nevertheless, a T-TIP investment chapter faced opposition in the United States. The simultaneous negotiations of T-TIP and the Trans-Pacific Partnership (TPP) 180 amplified public scrutiny of ISDS in the

(ACIEP) - comprising representatives from NGOs and the private sector-about how to modernize the U.S. Model BIT. Id.

1752012 Model BIT, supra note 25, arts. 12-13.

176 Compare 2004 Model BIT supra note 157, art. 28.10 ("[T]he Parties shall strive to reach an agreement that would have such appellate body review awards rendered under Article 34 in arbitrations commenced after the multilateral agreement enters into force between the Parties." (emphasis added)), with 2012 Model BIT, supra note 25, art. 28.10 ("In the event that an appellate mechanism for reviewing awards rendered by investor-State dispute settlement tribunals is developed in the future under other institutional arrangements, the Parties shall consider whether awards rendered under Article 34 should be subject to that appellate mechanism." (emphasis added)).

177 AKHTAR ET AL., supra note 50, at 1.

178 See White House Fact Sheet: Transatlantic Trade and Investment Partnership (T-TIP), U.S. TRADE REPRESENTATIVE (June 2013), https://ustr.gov/about-us/policy-offices/press-office/factsheets/2013/june/wh-ttip [https://perma.cc/ZC 2 W-39P7] (outlining the parties' goals for T-TIP negotiations, which included promoting "rules-based investment," trade and access to markets, and regulatory cooperation).

179 See Council Directive 11103/13, supra note 66, ๆ 23 (explaining that even before the European Union reformed its position on the ISDS mechanism to favor an Investment Court System, it entered the T-TIP negotiations with an emphasis on safeguarding states' right to regulate).

180 The TPP was a comprehensive, plurilateral FTA that the United States negotiated with eleven other countries while the United States was simultaneously negotiating T-TIP. IAN F. FERGusson, William H. COOPER, REMY JuRENAS \& BROCK R. WiLliams, CONG. RSCH. SERV., R42694, The Trans-Pacific PARTNERShiP NEgOtiations AND Issues FOR CONGRESS 2 (2013). Like draft forms of T-TIP, the TPP also had an investment chapter that 
United States, as civil society groups and certain politicians, including U.S. Senator Elizabeth Warren, sounded the alarm about ISDS undermining U.S. sovereignty and favoring multinational corporations. ${ }^{181}$

In 2015, President Barack Obama barely secured a renewal of Trade Promotion Authority ${ }^{182}$-and only with the significant support of Republicans ${ }^{183}$ - partly because of the inclusion of the traditional ISDS mechanism in the TPP. ${ }^{184}$ Trade Promotion Authority supplies USTR with negotiating objectives for international trade and investment agreements, and enables the President to submit implementing legislation for those agreements to Congress for consideration under an expedited timeframe, ${ }^{185}$ without the opportunity for Congress to amend the legislation. 186 For the context of renewed E.U.-U.S. FTA negotiations, it bears noting that the 2015 Trade Promotion Authority directs the USTR to seek to negotiate an "appellate body or similar mechanism to provide coherence to the interpretations of investment provisions in trade agreements." 187 Moreover, it

provided for ISDS. See id. at 41-42 (describing debate over whether to include the ISDS provision as "contentious"). Although the United States signed the TPP in February 2016, President Trump withdrew the United States from the pact in January 2017. IAN F. FERGUSSON \& BROCK R. WILlIAMS, CONG. RSCH. SERV., IN10822, TPP COUNTRIES SIGN NEW CPTPP AGREEMENT WITHOUT U.S. PARTICIPATION 1 (2018). The remaining eleven countries to the TPP Agreement replaced the TPP with the Comprehensive and Progressive Agreement for Trans-Pacific Partnership (CPTPP), which they signed in March 2018. BROCK R. WILLIAMS \& IAN F. FERGUSSON, CONG. RSCH. SERV., IF10ooo, TPP: OVERVIEW AND CURRENT STATUS 1 (2018). The CPTPP retains ISDS. Id. at 2. See generally Comprehensive and Progressive Agreement for Trans-Pacific Partnership (CPTPP), Mar. 8, 2018, https://www.mfat.govt.nz/en/trade/free-trade-agreements/free-tradeagreements-in-force/comprehensive-and-progressive-agreement-for-trans-pacific-partnershipcptpp/comprehensive-and-progressive-agreement-for-trans-pacific-partnership-text-and-resources [https://perma.cc/XGN4-8EGB].

181 See Warren, supra note 39 (discussing the perceived dangers of including an ISDS mechanism in international trade agreements).

182 Jonathan Weisman, Trade Authority Bill Wins Final Approval in Senate, N.Y. TIMES (June 24, 2015), https://www.nytimes.com/2015/06/25/business/trade-pact-senate-vote-obama.html [https://perma.cc/7 $\mathrm{MH}_{4}-\mathrm{MTM}_{2}$ ].

183 See id. ("The Senate cleared the so-called trade promotion bill 60 to 38, with 13 Democrats joining all but five Republicans.").

184 See, e.g., Ben White, Obama Aides: Warren "Baseless" on Trade, POLITICO (May 7, 2015, 12:03 AM), https://www.politico.com/story/2015/05/obama-aides-elizabeth-warren-trade-117703 [https://perma.cc/QB9SNYYU] (noting that U.S. Democratic Senator Elizabeth Warren expressed concern that including ISDS in the TPP agreement "could allow multinational corporations to sue in secretive international tribunals to gut U.S. laws while winning big taxpayer-funded awards").

185 See 19 U.S.C. $\S 2191$ (e) (providing that Senate and House committees have no longer than forty-five days to review proposed implementing legislation before that implementing legislation is put to a vote in each house of Congress).

$186 I d$. $\S 2191$ (d) ("No amendment to an implementing bill or approval resolution shall be in order in either the House of Representatives or the Senate; and no motion to suspend the application of this subsection shall be in order in either House ....").

187 Id. $\S 3802(\mathrm{~b})(3)(\mathrm{G})(\mathrm{iv})$. 
instructs USTR to negotiate IIAs that "provid[e] meaningful procedures for resolving investment disputes." 188

Amid the domestic criticism of ISDS stoked by the T-TIP and the TPP negotiations, USTR balked at the European Union's proposed Investment Court System, ${ }^{189}$ which the European Union formally proposed including in T-TIP in November 2015.190 Similarly, U.S. business groups opposed including the Investment Court System in T-TIP. ${ }^{191}$ Instead, the United States continued to push for traditional ISDS-that is, ad hoc arbitration, with no appeals mechanism-as modeled in the 2012 U.S. BIT.192 Ultimately, however, the investment chapter of T-TIP died with the termination of the T-TIP negotiations after the Trump Administration assumed office. ${ }^{193}$ As discussed below, the Trump Administration instead addressed international investment policy primarily in the context of renegotiating NAFTA.

\section{The Turn in U.S. International Investment Policy}

The United States-Mexico-Canada Free Trade Agreement (USCMA), negotiated at the behest of the Trump Administration to replace NAFTA and concluded on November 30, 2018,194 marked a shift in U.S. policy on the procedural aspects of ISDS. Although the USMCA maintained the core substantive investment protections from the 2012 Model BIT,195 it eliminated

$188 \mathrm{Id} . \S 3802(\mathrm{~b})(3)(\mathrm{F})$.

189 Hughes \& Blenkinsop, supra note 9.

190 See Transatlantic Trade and Investment Partnership: Trade in Services, Investment and ECommerce, $\S 3$, arts. 9-10, at 17-20 (2015), https://trade.ec.europa.eu/doclib/docs/2015/november/ tradoc_153955.pdf [https://perma.cc/AP25-WLBV] (outlining the proposed Investment Court System's tribunal of first instance and appellate mechanism).

191 See, e.g., Peter H. Chase, TTIP, Investor-State Dispute Settlement and the Rule of Law, U.S. CHAMBER OF COM. (Dec. 2, 2015, 11:00 AM), https://www.uschamber.com/issue-brief/ttipinvestor-state-dispute-settlement-and-the-rule-law [https://perma.cc/KFN6-JBUA] (describing the Investment Court System as "well-intentioned desire to respond to public criticism of ISDS in Europe" to solve "a problem that does not really exist").

192 See Hughes \& Blenkinsop, supra note 9 (reporting that U.S. Trade Representative Michael Froman said that the Obama administration's "baseline for TTIP" included the "model U.S. investor-state rules adopted in 2012").

193 See, e.g., Council Decision 6052/19, arts. 1-3, https://www.consilium.europa.eu/media/39180/sto6o52en19.pdf [https://perma.cc/ $\mathrm{N}_{3} \mathrm{E}_{2}-47 \mathrm{FN}$ ] (noting that "negotiating directives for the Transatlantic Trade and Investment Partnership have become obsolete" in light of the joint intention of the European Union and United States to negotiate a far narrower "agreement on the elimination of tariffs for industrial goods").

194 United States-Mexico-Canada Agreement, supra note 15; Bill Chappell, USMCA: Trump Signs New Trade Agreement with Mexico and Canada to Replace NAFTA, NPR (Nov. 30, 2018, 7:25 AM), https://www.npr.org/2018/11/30/672150010/usmca-trump-signs-new-trade-agreement-with-mexicoand-canada [https://perma.cc/Y2 $\left.\mathrm{V}_{2}-6 \mathrm{D}_{5} \mathrm{~J}\right]$.

195 See Agreement Between the United States of America, the United Mexican States, and Canada 7/1/20 Text, OFF. OF THE U.S. TRADE REPRESENTATIVE, https://ustr.gov/tradeagreements/free-trade-agreements/united-states-mexico-canada-agreement/agreement-between [https://perma.cc/8RVF-6WR6] [hereinafter USMCA]. Compare USMCA, supra, arts. 14.4 (National 
the ISDS mechanism between the United States and Canada, and narrowed its application between the United States and Mexico. ${ }^{196}$ Between the United States and Mexico, the USMCA preserves the ISDS mechanism for investors in most sectors, but only for a subset of the investment chapter's substantive investment protections: national treatment, most-favored nation treatment, and direct expropriation. ${ }^{197}$ Moreover, investors in most sectors may submit claims to arbitration only after they have exhausted local remedies-that is, after receiving a final judgment from a national court or after having pursued the claim in a national court for thirty months, whichever is earlier. ${ }^{198}$ The USMCA carves out an exception to those rules between the United States and Mexico for investors across five sectors-oil and gas, power generation, telecommunications, transportation, and infrastructure-whose claims arise out of a covered government contract.199 Those investors may bring ISDS claims that invoke the full range of investment protections provided by the USMCA, including indirect expropriation and fair and equitable treatment, and they do not need to exhaust local remedies.200

There are few publicly available statements explaining the decision to eliminate the ISDS mechanism between the United States and Canada in the USMCA. In July 2020, then-Deputy U.S. Trade Representative C.J. Mahoney reasoned that an ISDS mechanism was unnecessary between Canada and the United States given similarities in the two countries' judicial systems. ${ }^{201}$ A closer examination, however, suggests a more nuanced rationale for scrapping the ISDS mechanism between Canada and the United States. As discussed in subsection I.B.4, Canada and the European Union-two trading and investment partners that, as a general proposition, also have

Treatment), 14.5 (Most-Favored Nation Treatment), 14.6 (Minimum Standard of Treatment), and 14.8 (Expropriation and Compensation) with 2012 U.S. Model BIT, supra note 25, arts. 3 (National Treatment), 4 (Most-Favored Nation Treatment), 5 (Minimum Standard of Treatment), and 6 (Expropriation and Compensation).

196 See id., annex 14-D (containing provisions governing Mexico-United States investment disputes).

197 Id. art. 14.D.3.

198 Id. art. 14.D.5.1(b).

199 Id. annex 14-E, ๆ ๆ 2, 6(b).

$200 \mathrm{Id}$. annex 14-E, \ 2. Investors that do not operate in one of those five sectors, or that do operate in one of those five sectors but lack a covered government contract with the host state, can still claim that the host state has breached USMCA's minimum standard of treatment and indirect expropriation provisions; however, they need their home state to bring those claims on their behalf in a state-to-state proceeding. See id. art. 31.2(b) (explaining that the treaty parties can bring claims that another treaty party has breached "an obligation" of the USCMA to state-to-state arbitration).

201 See Baker Institute, USMCA's Entry into Force: Prospects and Challenges for North American Trade, YOUTUBE, at 36:55-37:50 (July 1, 2020), https://youtu.be/orgG-uH4UHo ("The case for an extrajudicial process to handle investment disputes between countries like the United States and Canada simply is just not all that compelling."). 
independent legal systems ${ }^{202}$-agreed to include the E.U.-developed investment court system in CETA.203 Although Canada has not publicly championed the Investment Court System as the European Union has, it has nevertheless endorsed the system by ratifying CETA. ${ }^{204}$ Indeed, during the USCMA negotiations, a spokesman for Canada's foreign ministry explicitly linked its negotiating position on USMCA to the CETA Investment Court System: "We've proposed a comprehensive investment chapter with a progressive approach to ISDS building off the CETA."205

Conversely, the United States has maintained its opposition to an Investment Court System model. For example, at the thirty-eighth session of UNCITRAL's Working Group III in January 2020, the U.S. delegation doubted the value of an appellate mechanism focused on developing coherent jurisprudence,206 a goal of the European Union's Investment Court System and its appeals mechanism207-although the U.S. delegation did seem to entertain the concept of a more narrowly tailored appellate mechanism that worked with other tools the United States has to ensure the correct interpretation of its IIAs.208 These tools include the provisions found in

202 To be sure, certain E.U. Member States, such as Poland and Hungary, have demonstrated weak commitments to the rule of law. See, e.g., Laurent Pech \& Kim Lane Scheppele, Illiberalism Within: Rule of Law Backsliding in the EU, 19 CAMBRIDGE Y.B. EUR. LEGAL STUD. 3, 8-12 (2017) (explaining how the rule of law in Hungary and Poland is "being systematically dismantled" as a "deliberate strategy of a ruling party," threatening the independence of the judiciary in those states).

203 See CETA, supra note 14, § F; see also supra subsection I.B.4.

204 See Canada-European Union Comprehensive Economic and Trade Agreement Implementation Act, S.C. 2017, c 6. (stating that the Act was assented to on May 16, 2017). The Act entered into force on September 21, 2017. An Act to Implement the Comprehensive Economic and Trade Agreement Between Canada and the European Union and its Member States and to Provide for Certain Other Measures, PARLIAMENT OF CAN., https://www.parl.ca/LEGISInfo/BillDetails.aspx?Language=E\&billId=8549249\& View=6 [https://perma.cc/FAQ9-LWHV] (Feb. 26, 2021).

205 Adam Behsudi \& Doug Palmer, Investor Dispute Provision in NAFTA Still at Impasse Ahead of Washington Meeting, POLITICO, (Feb. 21, 2018, 1:22 PM), https://www.politico.com/story/2018/o2/21/canadastands-firm-on-pursuing-bilateral-investor-dispute-process-with-mexico-in-nafta-356665 [https://perma.cc/ $\left.{ }_{3} \mathrm{WEW}-\mathrm{L}_{5} \mathrm{FQ}\right]$.

206 Statements of the U.S. Delegation at the Thirty-Eighth Session UNCITRAL Working Group III Session in Vienna, Austria, at 11:06:25-11:11:07 (Jan. 20, 2020), https://conferences.unite.un.org/carbonweb/public/uncitral/speakerslog/115dedb6-12ef-4f71-88beae318c802084 [https://perma.cc/B2X $\mathrm{X}_{9}-\mathrm{R}_{45} \mathrm{~S}$ ] [hereinafter U.S. Working Group III Statements] ("Searching for consistency where it may in fact may not need to apply may not be the best objective for strengthening the legitimacy and enhancing the correctness of decisions in the investor-state dispute settlement process.").

207 European Union, Possible Reform, supra note 56, \ 41 ("Predictability and consistency can only be effectively developed through the establishment of a standing mechanism with permanent, full-time adjudicators. This is the key problem of the existing system.").

208 U.S. Working Group III Statements, supra note 206, at 11:06:25-11:11:07 ("To the extent we are having an appellate mechanism create and enforce consistency in a stare decisis way ... really does take the duty of states to manage the meaning of treaties out of their hands and put it in a different institution."). 
modern U.S. IIAs allowing the non-disputing parties to submit briefs on the proper interpretation of the relevant IIA. ${ }^{209}$ The U.S. delegation's statements suggest that omission of an ISDS mechanism between Canada and the United States in the USMCA may have resulted partly from disagreement over Canada's endorsement of the Investment Court System; however, these statements also suggest that the United States might support an appellate mechanism focused squarely on the correctness of arbitral awards. This proposition is developed in subsection II.B.1. It remains unclear whether the Biden Administration will adopt the same position on an appellate procedure or will consider an appellate mechanism that also aims to promote coherence in international investment law.

The decision to narrow the scope of the ISDS mechanism in the USMCA between the United States and Mexico appears more straightforward: it stemmed from a Trump Administration concern that ISDS promoted the outsourcing of U.S. jobs to Mexico. In a 2018 House Ways and Means Committee hearing, then-U.S. Trade Representative Robert Lighthizer explained this position during his testimony in an exchange with then-House Ways and Means Chairman Kevin Brady. There, Ambassador Lighthizer laid out the Trump Administration's position on ISDS in the following terms:

So I think [ISDS] is something we have to think about very carefully. Our view was that rather than have this mandatory ISDS provision, which we think is a problem in terms of our sovereignty in the United States, encourages outsourcing and losing jobs in the United States, and by the way, lowering standards in a variety of places, that we should be very careful before we put something like that into place. ${ }^{210}$

Ambassador Lighthizer reiterated this view in a more recent New York Times op-ed, in which he characterized ISDS provisions in U.S. IIAs as a form of "political risk insurance for any American company that wanted to send jobs abroad." 211 The Ambassador did not support his position that ISDS encourages outsourcing before the Ways and Means Committee or in his oped with any evidence. ${ }^{212}$ Nevertheless, given the concern among some that

209 See, e.g., USCMA art. 14.D.7.2 ("The non-disputing . . Party may make oral and written submissions to the tribunal regarding the interpretation of this Agreement.").

210 Hearing on U.S. Trade Policy Agenda: Hearing Before H. Comm. on Ways E Means, 115th Cong. (2018) (statement of Robert E. Lighthizer, Ambassador, United States Trade Rep.).

211 Robert E. Lighthizer, Opinion, The Era of Offshoring U.S. Jobs Is Over, N.Y. TIMES (May 11, 2020), https://www.nytimes.com/2020/05/11/opinion/coronavirus-jobs-offshoring.html [https://perma. $\mathrm{cc} / 4$ VUU-AG2T].

212 Lauren Mandell, The Trump Administration's Impact on US Investment Policy, ICSID REV. 1, 12 (2020), https://academic.oup.com/icsidreview/advance-article/doi/10.1093/icsidreview/siaa023/5956108 [https://perma.cc/YS5N-HC8H] ("Ambassador Lighthizer did not provide then, or since, evidence to support a relationship between ISDS and job loss, and his critique of ISDS contains certain inaccuracies."). 
NAFTA's trade-as opposed to investment-chapters resulted in the loss of U.S. jobs to Mexico,213 and given the Ambassador's position that ISDS encourages outsourcing to lower wage countries, the decision to narrow the scope of ISDS between the United States and Mexico was unsurprising. In any event, the outsourcing concern does not apply with equal force to an investment chapter in an FTA between the United States and the European Union, as the United States is less concerned with the potential risk of outsourcing jobs to European countries.

In summary, the USMCA outcome on ISDS does not sound the death knell for ISDS in an E.U.-U.S. IIA. Instead, it suggests that any type of appellate mechanism pursued would need to be narrowly tailored to ensure that appellate tribunals (1) do not wrest away the authority of the United States and European Union to adopt final, binding interpretations of the IIA, and (2) allow the United States and European Union to deliver nondisputing-party submissions in investor-state disputes arising under the IIA.

\section{The Relevance of the U.S. Position on the WTO's Appellate Body}

Finally, any appellate mechanism to which the United States might agree in an E.U.-U.S. IIA must account for the longstanding U.S. criticism of the WTO's Appellate Body, which the Trump Administration allowed to cease functioning in December 2019.214 Accounting for this U.S. position is critical, because the European Union's effort to use an Investment Court System to promote consistency and coherence in international investment law cuts against one of the foremost reasons that the United States allowed the Appellate Body to collapse: the U.S. perception that the Appellate Body unjustifiably tried to create a system of de facto stare decisis through its reports, even though, according to the United States, the WTO Member States never intended for it to fulfill that function. 215

213 M. ANGEles Villarreal \& IAN F. FERguSSON, CONG. RSCH. SERV., R44981, NAFTA RENEgotiation and THE PROPOSED United STATES-MEXico-CANADA AgREEMENT (USMCA) 3 (2019) ("[L]abor groups and some consumer-advocacy groups argue that NAFTA resulted in outsourcing and lower wages that have had a negative effect on the U.S. economy.").

214 See, e.g., Alan Beattie, WTO to Suffer Heavy Blow as U.S. Stymies Appeals Body, FIN. TiMES (Dec. 8, 2019), https://www.ft.com/content/fof992b8-19c4-11ea-97df-cc63de1d73f4 [https://perma.cc/5ZBZ-67AW].

215 See, e.g., OFF. OF THE U.S. TRADE REPRESENTATIVE, REPORT ON THE APPELLATE BODY OF THE WORLD TRADE ORGANIZATION 7 (2020) [hereinafter REPORT ON THE APPELLATE BODY] (“The Appellate Body wrongly claims that its reports are entitled to be treated as binding precedent and must be followed by panels, absent 'cogent reasons."' (emphasis omitted)); Robert E. Lighthizer, Opinion, How to Set World Trade Straight, WALL ST. J. (Aug. 20, 2020, 7:32 PM EST), https://www.wsj.com/articles/how-to-setworld-trade-straight-11597966341?mod=searchresults\&page $=1 \&$ pos $=8$ [https://perma.cc/5E6C-B7TC] ("The Appellate Body was intended to have a limited role, quickly correcting errors of law, not fact. But over time it came to see itself as something else-a high court empowered to create a new common law of free trade.") 
To appreciate the importance of the U.S. concern that the Appellate Body unjustifiably accorded its own reports precedential weight, it is critical to understand the basic legal structure that governs WTO dispute settlement. The Dispute Settlement Body (DSB), which comprises all the WTO members, administers the WTO's dispute settlement system. ${ }^{216}$ In administering the dispute settlement system, it formally adopts reports issued by WTO panels and the WTO's Appellate Body.217

Articles Six through Sixteen of the Dispute Settlement Understanding (DSU) establish the process for panels to adjudicate disputes between WTO members. Panels function like ad hoc tribunals in investor-state arbitration in that they comprise three members ${ }^{218}$ and are composed for the sole purpose of adjudicating a particular dispute between WTO members.219 More specifically, panels find facts and apply WTO law to those facts.220 Although the WTO's Secretariat draws panelists for particular disputes from a roster that WTO members help to populate,221 and the WTO's budget covers panelists' expenses, ${ }^{222}$ panelists are not employees of the WTO, just as arbitrators in investor-state disputes are not employees of administering or appointing institutions.

Article Seventeen of the DSU establishes the rules for appellate review of reports issued by WTO panels. It limits the Appellate Body's review of appeals to issues of law,223 allowing it to "uphold, modify or reverse the legal findings and conclusions of the panel" below.224 As is relevant for the U.S. critique of the Appellate Body, Article Seventeen provides that the Appellate Body issues reports-not decisions or awards-which the WTO Member States, acting together as the DSB, must formally adopt or reject.225 In other words, the WTO Member States technically have the final decision on interpretation and application of the WTO's agreements to discrete disputes.226

Additionally, Article 3.2 of the DSU provides that the adoption of such reports cannot "add to or diminish the rights and obligations provided in the

216 Understanding on Rules and Procedures Governing the Settlement of Disputes art. 2.1, Apr. 15, 1994, Marrakesh Agreement Establishing the World Trade Organization, Annex 2, 1869 U.N.T.S. 401 [hereinafter DSU].

217 Id.

218 Id. art. 8.5.

219 Id. arts. 6-7 (describing how panels are established and providing panels' terms of reference).

$220 \mathrm{Id}$. art. 11.

$221 \mathrm{Id}$. art. 8.4.

222 Id. art. 8.11.

$223 \mathrm{Id}$. art. 17.6 .

224 Id. art. $17 \cdot 13$.

225 Id. art. 17.14

226 That said, the default position created by Article 17.14 of the DSU is that the DSB will adopt Appellate Body reports unless the members agree "by consensus[,] not to adopt" a given report. Id. 
covered agreements."227 Instead, a related agreement, the Marrakesh Agreement Establishing the World Trade Organization (the WTO Agreement), provides a specific procedure for WTO Member States to adopt binding interpretations of the WTO agreements.228 This procedure resembles the NAFTA procedure that Canada, Mexico, and the United States used to adopt a binding interpretation of NAFTA Article 1105(1).229

In its 174-page report on the alleged errors of the Appellate Body, the United States argued that the Appellate Body ignored the text and structure of the DSU and the Marrakesh Agreement by instructing panels to follow its legal interpretations in future disputes involving the same WTO agreement provisions. ${ }^{230}$ More specifically, the United States identified the Appellate Body's Report in United States-Stainless Steel (Mexico) as introducing the flawed concept that panels should treat prior Appellate Body reports as de facto precedent in order to ensure predictability and stability in the interpretation of the WTO's agreements.231 According to the United States, this approach threatened to "add to or diminish" the rights of the WTO's Member States, an action prohibited by Article 3.2 of the DSU.232 In criticizing the Appellate Body's approach, however, the United States did not reject the proposition that Appellate Body reports can serve as persuasive authority in future disputes.233 Rather, it rejected the view that the DSU and the Marrakesh Agreement leave the Appellate Body with any room to assign its reports precedential weight. 234

Because the U.S. perception that the Appellate Body assigned its own reports precedential value motivated the U.S. decision to allow the Appellate Body to collapse, it is likely that similar concerns would animate the United States' evaluation of an appellate mechanism in an E.U.-U.S. IIA. Nonetheless, as noted in the preceding paragraph, the U.S. Appellate Body critique also

227 Id. art. 3.2 .

228 See Marrakesh Agreement Establishing the World Trade Organization art. IX:2, Apr. 15, 1994, 1867 U.N.T.S. 154 [hereinafter Marrakesh Agreement] (providing that the "Ministerial Conference and the General Council shall have the exclusive authority to adopt interpretations" of trade agreements and that such interpretations shall be adopted "by a three-fourths majority of the Members").

229 For an extended discussion of NAFTA Article 1105(1), see supra subsection I.C.1.

230 See supra note 215.

231 Id. at 59; see Appellate Body Report, United States-Final Anti-Dumping Measures on Stainless Steel from Mexico, ๆ ๆ 160, 162, WTO Doc. WT/DS344/AB/R (adopted Apr. 30, 2008) ("Ensuring 'security and predictability' in the dispute settlement system, as contemplated in Article 3.2 of the DSU, implies that, absent cogent reasons, an adjudicatory body will resolve the same legal question in the same way in a subsequent case.").

232 DSU, supra note 216 , art. 3.2.

233 REPORT ON THE APPELLATE BODY, supra note 215, at 60 ("There is nothing surprising about the fact that parties in WTO disputes cite to reports to the extent they may consider them persuasive. The United States expects this, does this itself, and anticipates panels will do the same."). $234 \mathrm{Id}$. at 6o-61. 
recognizes the role for allowing appellate reports to serve as persuasive authority. 235 This suggests that the United States might endorse an appeals mechanism in an E.U.-U.S. IIA if the IIA provided explicitly that appellate decisions lacked de jure or de facto stare decisis effect, and if the United States and European Union reserved the right to deliver non-disputing-party submissions and to adopt authoritative interpretations of the IIA. This Comment's proposed appellate mechanism incorporates these assumptions.

\section{ENHANCING THE LEGITIMACY OF INTERNATIONAL INVESTMENT LAW AND PROTECTING TRANSATLANTIC INVESTMENT THROUGH AN E.U.-U.S. IIA}

Within the bounds of their negotiating positions described in Part I, the European Union and the United States have an opportunity to negotiate an IIA that reasserts the legitimacy of international investment law and protects transatlantic investment. This logic is developed in Section A below. Section $\mathrm{B}$, in turn, proposes the design of such an IIA. First, it advocates for dispute settlement that preserves ad hoc arbitration but adds an appellate mechanism embedded within ICSID. Second, it argues that the European Union and United States can draft substantive provisions that create more ex ante certainty for investors and states about what measures will and will not breach the treaty's substantive obligations.

\section{A. The Rationale for Investor-State Dispute Settlement in an E.U.-U.S. FTA}

Despite their differences on how to tackle international investment law's legitimacy crisis, the European Union and United States should include an investment chapter in an FTA that they negotiate. First, given their collective economic power and consistent pursuit of FTAs with other countries, they have the opportunity to design a progressive investment chapter that charts a new path for international investment law. Second, a properly drafted IIA between the European Union and United States will simultaneously establish a more stable and attractive transatlantic investment environment and ensure that legitimate public policy measures do not trigger host-state liability.

1. Strengthening the Legitimacy of International Investment Law

Notwithstanding the gap between the current U.S. and E.U. positions on ISDS, the opportunity to redirect the trajectory of international investment law is too important for the United States and the European Union to jettison any form of ISDS in an E.U.-U.S. FTA. Given the combined influence of 
the European Union and United States on international investment,236 a progressive investment chapter in an E.U.-U.S. FTA would help shape the rules of the international investment law regime for the rest of the twentyfirst century. Specifically, an investment chapter in an E.U.-U.S. FTA would create a vehicle to address the principal procedural and substantive concerns raised in the multilateral debate on ISDS reform.

The alternatives - an investment chapter with no ISDS mechanism or no investment chapter at all-risk letting a gap in the E.U. and U.S. positions widen into a chasm, as the European Union forges ahead with its vision for a Multilateral Investment Court and the United States presses for IIAs with traditional, ad hoc ISDS or removes the ISDS mechanism from its future IIAs altogether. The pursuit of divergent IIA models is not in the long-term interest of the United States or the European Union. From the U.S. perspective, returning to state-to-state dispute settlement, which would follow from excluding the ISDS mechanism in IIAs, risks repoliticizing investor-state disputes - thereby undermining the predictability and stability that international investment law is supposed to support237-and putting U.S. businesses at a competitive disadvantage vis-à-vis investors from other countries that do have access to ISDS with the European Union.238 From the E.U. perspective, a Multilateral Investment Court without U.S. support is unlikely to gain much traction, given that the United States accounts for the largest share of inward and outward FDI of any country in the world.239

Removing ISDS from an E.U.-U.S. FTA would also undermine the development of international investment law by creating contradictory positions in E.U. and U.S. international investment law policies. Specifically, removing ISDS from an E.U.-U.S. FTA on the ground that both the United States and the European Union (and many of its Member States) have welldeveloped domestic legal systems might undermine support for ISDS from developing countries, with whom both the European Union and the United States have negotiated IIAs that do include ISDS. In other words, if the European Union and United States scrapped ISDS from an E.U.-U.S. IIA, developing countries might justifiably perceive the inclusion of ISDS in developed country-developing country IIAs as discriminating against them vis-

236 See AKHTAR, supra note 7, at 2 fig.3.

237 See supra notes 21-29 and accompanying text (explaining the politicized dispute between China and the United States).

238 See supra notes $30-33$ and accompanying text (explaining how IIAs reduce the risks associated with foreign investment).

239 JAMES K. JACKSON, CONG. RSCH. SERV., RS21118, U.S. DiRECT INVESTMENT ABROAD: TRENDS AND CURRENT ISSUES 1 (2017) ("The United States occupies a unique position in the global economy as the largest investor and the largest recipient of foreign direct investment (FDI)."). 
à-vis developed country-developed country IIAs. ${ }^{240}$ And developed countries choosing to include ISDS because of their static perception of a treaty counterparty's legal system undermines the legitimacy of international investment law: it reduces ISDS to a realpolitik calculus, which is precisely the type of political maneuvering that ISDS was designed to eliminate. ${ }^{241}$

Moreover, if the European Union were to argue for removing ISDS from an E.U.-U.S. IIA on the basis that foreign investors in developed countries should rely on domestic legal systems, it would undermine the legitimacy of CETA, which includes ISDS between two developed trade and investment partners, albeit using the European Union's preferred Investment Court System format. ${ }^{242}$

\section{The Importance of Bilateral Investment Between the European Union and United States}

The second reason for including ISDS in an E.U.-U.S. FTA is pragmatic and addresses the more immediate interests of the United States and European Union: ensuring the stability and protection of a significant, mutually beneficial volume of transatlantic FDI. In 2019, for example, cumulative FDI stock exchanged between the United States and the European Union approached $\$ 5$ trillion, making it the largest bilateral FDI relationship in the world. ${ }^{243}$ Moreover, E.U.-U.S. FDI supports 4.4 million jobs in the European Union and 4.1 million jobs in the United States. ${ }^{244}$ In short, ensuring the predictability and stability of this FDI is important to both the United States and European Union. Although this volume of FDI stock has accumulated in the absence of an IIA between the United States and European Union, ${ }^{245}$ an IIA with ISDS would provide a neutral forum for

240 Peter H. Chase, TTIP, Investor-State Dispute Settlement and the Rule of Law, 14 EUROPEAN VIEW 217, 223 (2015) ("Saying ISDS is not needed for countries with 'developed' systems of law also raises moral and ethical questions. Who is to judge whether the legal system of one country is better or worse than that of another's? Indeed, even posing the question has echoes of colonialism ....").

241 See, e.g., Pauweyln, supra note 18, at 38 ("[T] hat states agreed to private standing [in ISDS] follows a longer historical trend of states eager to dissociate themselves from disputes over treatment of aliens in order to allow for more stable international intercourse. . . Private standing was granted ... to avoid irritating broader political relations.").

242 CETA, supra note 14, arts. 8.18-.45.

243 AKHTAR, supra note 7, at 2 fig.3.

244 Id. at 2.

245 The United States has IIAs with certain E.U. Member States: Bulgaria, Croatia, the Czech Republic, Estonia, Latvia, Lithuania, Poland, Romania, and Slovakia. See United States Bilateral Investment Treaties, U.S. DEP'T OF STATE, https://www.state.gov/investment-affairs/bilateralinvestment-treaties-and-related-agreements/united-states-bilateral-investment-treaties [https:// perma.cc/W8NW-9 $\left.\mathrm{P}_{4} \mathrm{P}\right]$. But all these IIAs entered into force in the 1990s, see id., and therefore do not incorporate progressive features of the 2004 and 2012 U.S. Model BITs, including their emphasis 
resolving investment disputes that will inevitably arise between the two parties and their investors.

Because an IIA would create a neutral forum for resolving investment disputes, it would also preempt the use of unilateral, retaliatory instruments by host governments on behalf of their investors, which have become increasingly popular in the current international economic environmentincluding in economic relations between the United States and European Union. For example, consider the tariffs the United States has authorized against French imports in retaliation for a French tax on digital services companies operating in France. ${ }^{246}$ The French tax imposes a three percent charge on the gross revenues that digital services providers generate from providing "digital interface" services and "targeted advertising" services in France. 247 The tax applies only to companies generating annual revenues of at least $€ 25$ million in France and $€ 750$ million globally from the pertinent digital interface services or targeted advertising. 248 In investigating the tax under Section 301 of the 1974 Trade Act, USTR concluded that the tax constituted de facto discrimination against U.S. technology companies operating in France, because the design, structure, and operation of the tax led it to apply to large, U.S. technology companies, such as Google, Apple, Facebook, and Amazon-but not to smaller France-based technology companies or to large, France-based advertising companies that generated less than $€ 750$ million in global revenues from targeted advertising. ${ }^{249}$ In other words, according to the Section 301 report, France designed the tax so that it would target large U.S. technology companies and exempt homegrown technology and technology-enabled champions.

The conclusions of the Section 301 report led the United States to authorize tariffs on roughly $\$ 1.3$ billion of French imports at an ad valorem rate of $25 \%$, although the United States has delayed the implementation of those duties. ${ }^{250}$ As is relevant for this Comment, the United States authorized the imposition of tariffs despite protests from U.S.-based importers who

on states' policy space and defining substantive obligations more precisely. See supra notes $153-76$ and accompanying text (explaining the 2004 and 2012 Model BITs).

246 OfF. OF THE U.S. TRADE REPRESENTATIVE, REPORT ON FRANCE'S Digital SERVICES TAX PREPARED IN THE INVESTIGATION UNDER SECTION 301 OF THE TRADE ACT OF 1974, at 1 (2019) [hereinafter SECTION 301 FRANCE's DigITAL SERVICES TAX (DST)].

247 Id.

248 Id.

249 See id. at 31-47 ("[T]he record of this investigation, including comments by interested persons and other evidence, suggests that the global revenue thresholds of the French [digital services tax] focus the tax on U.S.-based companies, while exempting many non-U.S.-based companies that provide the taxable services in France.").

250 Notice of Action in the Section 301 Investigation of France's Digital Services Tax, 85 Fed. Reg. at 43,292, 43,293 (July 16, 2020). 
argued that the higher tariffs would cause them economic hardship.251 In other words, by authorizing tariffs as a countermeasure to France's Digital Services Tax, the United States proposed a remedy that benefitted one group of U.S. companies (digital services providers), while harming another group of U.S. companies (U.S. importers and distributors of goods from Europe).

As with the tariffs imposed under the Section 301 investigation into China's intellectual property practices,252 these tariffs and their adverse consequences for U.S. businesses could have been avoided if an IIA were in place between the United States and European Union: under an E.U.-U.S. IIA, the U.S. companies subject to de facto discrimination by the French government under the tax scheme could bring claims for violations of the IIA's national treatment obligations. ${ }^{253}$ Unlike the tariffs that the United States authorized against France following the Section 301 investigation, the remedy in a successful ISDS claim against France-damages-would not cause collateral damage to U.S. businesses. 254

To date, investor-state arbitration tribunals apparently have not decided whether a company's social media operations in a given host state constitutes a protected investment under IIAs. But analogizing from investor-state jurisprudence suggests that it probably does: tribunals have treated privateparty contracts that involve a nexus with the host state as protected investments, ${ }^{255}$ and U.S.-based technology companies' digital services

251 See, e.g., SECTION 301 FRANCE's Digital SERVICES TAX (DST), supra note 246, at 85-124 , (reporting statements from several U.S. wine importers and distributors whose businesses would suffer if the United States imposed tariffs on imports of French products as a countermeasure to the digital services tax).

252 For a discussion of this investigation, see supra Section I.A.

253 See e.g., SECTION 301 FRANCE'S Digital SERVICES TAX (DST), supra note 246, at 12-27 (finding that the French digital services tax enacted on July 24, 2019, discriminates against U.S. technology companies vis-à-vis French technology companies); 2012 Model BIT, supra note 25, art. 3 (providing that a party should treat investors of the other party no less favorably than its own investors).

254 See Naboth van den Broek \& Danielle Morris, The EU's Proposed Investment Court and WTO Dispute Settlement: A Comparison and Lessons Learned, in 2 EUROPEAN INVESTMENT LAW \& ARBitration REVIEW, 36, 64 (Loukas Mistelis \& Nikos Lavranos eds., 2017) (arguing that damages under investor-state disputes "do not harm innocent bystanders, in the way that WTO [trade] retaliatory measures do" and that "[i]n some ways, the remedies foreseen in the ISDS context may even be considered preferable over the more crude, tit-for-tat system of remedies foreseen in trade regimes such as the WTO").

255 Enikő Horváth \& Severin Klinkmüller, The Concept of 'Investment' in the Digital Economy: The Case of Social Media Companies, 20 J. WORLD INV. \& TRADE 577, 591-604 (2019) (explaining the circumstances under which tribunals have treated contracts as protected investments under IIAs and the implications of those tribunal decisions on how contracts underpinning social-media operations may be treated as investments). More specifically, a contract between private parties may have a sufficient nexus with a host state for the contract to qualify as a protected investment under an IIA when the contract involves the provision of services in the host state. Id. at 595. And although the services that digital services providers offer are intangible, they nevertheless are delivered and 
activities in France involve such contracts.256 Moreover, tribunals have exercised jurisdiction when they found that discrete transactions cohered to form a single economic enterprise 257 a scenario that characterizes digital services providers' universe of contracts with advertisers providing targeted advertisements to consumers in France and digital interface users in France. 258

An E.U.-U.S. IIA would also protect U.S. investors in the European Union against mistreatment by certain E.U. Member States that have increasingly disregarded the rule of law-principally, Hungary and Poland.259 If the European Union cannot by its own legal or political mechanisms persuade Romania and Poland to respect the rule of law, perhaps raising the specter of paying damages to U.S. investors suing them under an ISDS mechanism will.260 And if Romania and Poland refused to honor their commitment to pay

consumed in a particular host state, thereby establishing a sufficient nexus. See id. at 595-97 ("[T]he commercial services offered by social media companies pursuant to third-party contracts with individuals and entities in any given country are used-and are intended for use-by the (targeted) individuals and entities in that specific country, or a part thereof.").

256 See SECTION 301 FRANCE'S Digital SERVICES TAX (DST), supra note 246, at 12-21 (describing how France's digital services tax applies to revenue generated from U.S. companies' digital interface and targeted advertising services that have been provided in France). Digital interface providers, the first class of digital services companies subject to France's Digital Services Tax, generate revenue through contracts with the users of their platforms. See id. at 18 . Providers of targeted advertising services, the second class of companies subject to France's Digital Services Tax, generate revenue through contracts with advertisers seeking to place their advertisements in front of certain consumers. See id.

257 Horváth \& Klinkmüller, supra note 255, at 609-11.

258 See, e.g., SECtion 301 FrancE's Digital Services TAX (DST), supra note 246, at 20 ("[F]or Internet advertising, a company like Facebook could not go one-by-one through its contracts with advertisers and assess the share of ads placed under each contract that were seen by French users.").

259 See, e.g., European Parliament Press Release 20200109IPR69907, Rule of Law in Poland and Hungary Has Worsened (Jan. 16, 2020), https://www.europarl.europa.eu/pdfs/news/expert /2020/1/press_release/20200109IPR69907/20200109IPR69907_en.pdf [https://perma.cc/3RG8-GJF8] (announcing E.U. concerns about the status of discussions with Hungry and Poland and the continued misalignment of those countries with the founding values of the European Union, including the rule of law). Hungary and Poland have opposed an E.U. mechanism that would condition access to E.U. funds on the "respect for EU values, including the independence of judges." Mehreen Khan, Michael Peel \& Valerie Hopkins, EU Reaches Deal to Suspend Funds to Member States that Breach Rule of Law, FIN. TiMES (Nov. 5, 2020), https://www.ft.com/content/523adf3c-oc4a-41a7-9527-20b36bo39a99 [https:// perma.cc/M9WF-33US]. Although the United States has an IIA with Poland, it was concluded in 1994, see Treaty on Business and Economic Relations, Pol.-U.S., Mar. 21, 1990, S. TREATY DOC. No. 101-18 (1990), and therefore does not reflect the current U.S. position on ISDS, especially safeguarding states' right to regulate. Thus, with respect to Poland, a modern IIA between the United States and the European Union would align better with the current U.S. position on international investment law. See supra subsection I.C.3. The United States does not have an IIA with Hungary. Hungary, UNITED NATIONS CONF. ON TRADE \& DEV., https://investmentpolicy.unctad.org/international-investmentagreements/countries/94/hungary [https://perma.cc/P5EB-DE26].

260 Cf. R. Daniel Kelemen, Law, Fiscal Federalism, and Austerity, 22 IND. J. GLO. LEGAL STUD. 379, 395-98 (2015) (discussing the value of bond markets in holding E.U. Member States accountable to their fiscal austerity pledges). 
damages they incurred through ISDS proceedings, they would undermine their ability to attract future FDI and sovereign debt financing. ${ }^{261}$

The European Union likewise has compelling reasons to negotiate an investment chapter that protects its investors who are investing in the United States. In 2018, investors based in E.U. Member States, excluding the United Kingdom, accounted for about \$2 trillion in FDI stock in the United States. ${ }^{262}$ Thus, the European Union has a significant interest in ensuring that its investors in the United States receive nondiscriminatory, equitable treatment. Although the United States has a well-developed rule of law,263 it is not immune from taking measures that can ground investor-state claims against the United States. ${ }^{264}$

Moreover, the argument that U.S. or E.U. investors should pursue claims against the European Union and United States, respectively, in domestic courts is inconsistent with both governments' positions on WTO dispute settlement. 265 If one were to accept the logic that investors should pursue all claims of IIA breaches in domestic courts of a host state, then one would also need to conclude that exporters sending exports to that same state should pursue all claims of trade-agreement breaches in host-state courts, without recourse to the WTO's dispute settlement system. Of course, neither the European Union nor the United States has suggested abandoning the WTO's dispute settlement system: each recognizes the value of the neutral adjudication of international disputes.266 Indeed, ensuring a level playing

261 Cf. Sykes, supra note 30, at 501 ("A host country that refuses to abide by ISDS rulings destroys its credibility with future investors and undermines its own rationale for entering IIA commitments to reduce inefficient risk in the first place.").

262 AKHTAR, supra note 7, at 2 fig.3.

263 See, e.g., United States, WORLD JUST. PROJECT, https://www.worldjusticeproject.org/ruleof-law-index/country/2020/United\%20States [https://perma.cc/3243-NGKG] (ranking the United States twenty-first out of 128 measured countries on its rule-of-law strength).

264 See, e.g., TransCanada Corp. v. United States of America, ICSID Case No. ARB/16/21, Claimant's Request for Arbitration, Iा 9-72, 89 (June 24, 2016), https://www.italaw.com/sites/default/files/casedocuments/italaw7407.pdf [https://perma.cc/SE4X-7A59] (alleging that the United States breached several NAFTA provisions by delaying its processing of, and ultimately denying, TransCanada's application for a presidential permit to build the Keystone XL pipeline); see also USITC Report, supra note 36, at 196-97 box 8.1 (counting investor-state cases filed against the United States, as well as Canada and Mexico).

265 See supra subsection I.C.4. Whatever its grievances with the WTO's Appellate Body, the United States has not signaled an interest in abandoning the WTO's dispute settlement system.

266 Even though the United States has allowed the WTO's Appellate Body to collapse, it has stated that it remains committed to the WTO's dispute settlement system. REPORT ON THE APPELLATE BODY, supra note 215, at 3 ("Lasting and effective reform of the WTO dispute settlement system requires all WTO Members to come to terms with the failings of the Appellate Body." (emphasis added)). The European Union has expressed even stronger support for the WTO's dispute settlement system, going so far as to establish an interim appellate mechanism with certain other WTO members while the entire WTO membership determines how to revive the Appellate Body. See European Commission Press Release, EU and 15 World Trade Organization Members Establish Contingency Appeal Arrangement for Trade Disputes (Mar. 27, 2020), https://trade.ec.europa.eu /doclib/press/index.cfm?id=2127 [https://perma.cc/TS8M-W6MN] (announcing the establishment of 
field for its investors was one of the European Union's core objectives in negotiating an investment chapter in the first round of the Transatlantic Trade and Investment Partnership negotiations. ${ }^{267}$

Similarly, the argument that foreign investors should sue host governments in domestic courts tugs against longstanding U.S. law that allows plaintiffs to bring diversity suits applying state law in federal district courts, ${ }^{268}$ and that allows defendants in diversity proceedings to remove civil actions filed in state courts to federal district courts. ${ }^{269}$ Diversity jurisdiction and the right to remove diversity cases probably originates from a concern that state courts may tilt the playing field in favor of the home party. 270 Indeed, federal courts continue to cite this rationale as the purpose behind the diversity and removal statutes. ${ }^{271}$

In sum, the United States and the European Union should include an investment chapter with investor-state arbitration for two core reasons. First, negotiating a modern investment chapter would promote the legitimacy of international investment law, as it would signal to the rest of the world that the decision to negotiate an IIA does not reduce ISDS to a realpolitik calculus in which developed states exercise leverage over developing states. Second, an investment chapter would provide a neutral forum in which to resolve investment disputes that will inevitably arise between the two parties given the volume of FDI exchanged between the United States and European Union. Having established the rationale for an E.U.-U.S. IIA, this Comment turns to how to design an investment chapter that reflects this rationale.

the Multiparty Interim Appeal Arbitration Arrangement, an appellate tribunal designed to operate while the WTO Appellate body is not functioning).

267 Council Directive 11103/13, supra note 66, \ 23 (Oct. 9, 2014) (explaining that T-TIP's investment chapter should focus on providing "a level playing field for investors in the US and in the EU").

268 See 28 U.S.C. $\$ 1332(\mathrm{a})(1)$ (providing that federal district courts "shall have original jurisdiction of all civil actions" in which the amount in controversy exceeds $\$ 75,000$ and the dispute involves citizens of different states).

269 See id. $\S 1441(\mathrm{a})$ (providing that defendants in civil actions subject to the original jurisdiction of federal district courts may remove such actions from state court to federal district court); see also CHARles A. WRIGHT \& ARTHUR R. Miller, ${ }_{14}$ C FEDERAL PRACTICE AND PROCEDURE $\S 3721$, Westlaw (database updated Oct. 2020) ("[E]ver since the original Judiciary Act of 1789 , there has been some provision for the removal of cases from state to federal courts.")

270 See id. ("Like the diversity of citizenship and alienage jurisdiction of the federal courts, the original right to remove probably was designed to protect nonresidents from the local prejudices of state courts.")

271 See, e.g., Lively v. Wild Oats Mkts., Inc., 456 F.3d 933, 940 (9th Cir. 2006) ("Removal based on diversity jurisdiction is intended to protect out-of-state defendants from possible prejudices in state court."); J.A. Olson Co. v. City of Winona, 818 F.2d 401, 404 (5th Cir. 1987) ("Diversity jurisdiction exists for the purpose of providing a federal forum for out-of-state litigants where they are free from prejudice in favor of a local litigant."); see also WRIGHT \& MILLER, supra note 269, $\S 3721$ (collecting cases and explaining that federal judges continue to cite protection against actual or perceived state-court prejudice as the rationale behind diversity jurisdiction). 


\section{B. The Design of an E.U.-U.S. FTA Investment Chapter}

This Comment's proposals for the core provisions of an E.U.-U.S. FTA investment chapter map onto two broad categories: (1) a dispute settlement system that combines traditional, ad hoc arbitration in the first instance with a new appellate mechanism; and (2) substantive provisions governing investment protection.

\section{Dispute Settlement}

Most of the friction in the U.S. and E.U. positions on international investment law lies in the mechanism for resolving investor-state disputes. The following proposal should strike a workable middle-ground between the E.U. and U.S. positions: (a) the preservation of ad hoc ISDS in the first instance, with a number of procedural improvements on which the United States and European Union agree; and (b) the addition of an appellate mechanism at ICSID, to which investor-state disputes arising out of the E.U.-U.S. FTA could be appealed. This structure would preserve the benefits of ad hoc arbitration while introducing a mechanism that would ensure the legal correctness of arbitral decisions-without creating a system of precedent that would bind the European Union, United States, or their investors in future disputes. The following subsections lay out the core elements of this proposed system.

\section{a. Traditional Ad Hoc Arbitration in the First Instance}

This Comment argues for the preservation of ad hoc arbitration in the first instance because (1) many of the flaws in the existing ad hoc arbitration system have been resolved by the United States in its recent IIAs; and (2) ad hoc arbitration is fundamentally a fair, neutral process of adjudication that accords with international investment law's objective of depoliticizing investor-state disputes.

First, the rationale for permanent, first-instance tribunals has abated, as the United States and other countries have demonstrated that tougher dispute resolution provisions can remedy perceived ISDS shortcomings without abandoning the ad hoc arbitration model. A comparison of the European Union's and United States' recently concluded IIAs demonstrates that, without the United States needing to abandon ad hoc arbitration, U.S. IIAs have tackled the same core procedural issues as the E.U. IIAs: a lack of transparency;272 rules governing the independence and impartiality of

272 Compare USMCA, supra note 195, art. 14.D.8.2 ("The tribunal shall conduct hearings open to the public and shall determine, in consultation with the disputing parties, the appropriate 
arbitrators; 273 the consolidation of parallel proceedings; 274 lawyers serving as arbitrators in one case and as counsel in the next;275 and the disposition of meritless claims. ${ }^{276}$ These concerns lie at the heart of the global legitimacy crisis facing the ISDS regime. ${ }^{277}$ Accordingly, an IIA between the European Union and United States that preserved ad hoc arbitration in the first instance would help cement the emerging standards both parties have already endorsed, without needing to introduce the complexity and bureaucracy posed by a standing, first instance tribunal.

Second, preserving ad hoc arbitration in an IIA between the European Union and United States is worthwhile because ad hoc arbitration is fundamentally a neutral, fair method for adjudicating disputes. In traditional, ad hoc arbitration, the investor appoints one arbitrator, the respondent country appoints another arbitrator, and the parties together appoint the chair of the tribunal.278 Absent agreement between the parties on the chair, the institution administering the arbitration appoints the chair.279 Thus, unlike the European Union's Investment Court System, in which countries, not investors, appoint all the arbitrators who constitute tribunal divisions, in ad hoc arbitration, each litigant has an equal influence on the composition of

logistical arrangements."), with CETA, supra note 14, art. 8.36.5 ("Hearings shall be open to the public.").

273 Compare USMCA, supra note 195, art. 14.D.6.5(a) (mandating that arbitrators "comply with the International Bar Association Guidelines on Conflicts of Interest in International Arbitration"), with CETA, supra note 14, art. 8.30.1 (same).

274 Compare USMCA, supra note 195, art. 14.D.12.1 (permitting the ICSID Secretary-General to consolidate proceedings), with CETA, supra note 14, art. 8.43.1 (providing a procedure for parties to request that tribunals consolidate proceedings).

275 Compare USMCA, supra note 195, art. 14.D.6.5(c) (providing that arbitrators shall not act as counsel or party-appointed expert or witness in another USMCA arbitration for the duration of the proceedings in which they are serving as arbitrators), with CETA, supra note 14, art. 8.30.1 ("[U]pon appointment, [members of the tribunal] shall refrain from acting as counsel or as party-appointed expert or witness in any pending or new investment dispute under this or any other international agreement.").

276 Compare USMCA, supra note 195, art. 14.D.7.4 ("[A] tribunal shall address and decide as a preliminary question any objection by the respondent that, as a matter of law ... a claim is manifestly without legal merit."), with CETA, supra note 14, art. 8.33.1 (“[T]he Tribunal shall address and decide as a preliminary question any objection by the respondent that, as a matter of law, a claim ... submitted pursuant to Article 8.23 is not a claim for which an award in favour of the claimant may be made under this Section .....").

277 See, e.g., U.N., Possible Reform, supra note 19, If 20 (listing concerns about the arbitral process and potential decision-makers that Member States expressed as "undermin[ing] the legitimacy of the ISDS regime and its democratic accountability").

278 See, e.g. International Centre for Settlement of Investment Disputes Rules of Procedure for Arbitration Proceedings (Arbitration Rules) 3 (explaining the appointment process of arbitrators to the tribunal).

279 See, e.g., International Centre for Settlement of Investment Disputes Rules of Procedure for Arbitration Proceedings (Arbitration Rules) 4(1) (providing for the Chair of ICSID's Administrative Council to select a tribunal president if the parties request the Chair to do so or if the parties cannot agree on a tribunal president). 
the tribunal that will hear its case. Further, institutional arbitration rules contain robust procedures for challenging arbitrators for lack of independence or impartiality. ${ }^{280}$

\section{b. The Appellate Mechanism}

Despite the virtues of the improved ad hoc arbitration model, it seems clear that some form of appellate mechanism will be necessary to ensure the conclusion of an IIA between the European Union and the United States. That is at least in part because, as described in Section I.B, the European Parliament and the CJEU have sanctioned E.U. IIAs that include an appellate mechanism, and because the European Union has risked too much political capital on the concept of appellate review in its IIAs to walk that position back. And although the United States has assailed the WTO's Appellate Body, it has not publicly rejected an appellate mechanism in ISDS. In fact, as noted in subsection I.C.1, the 2004 and 2012 Model BITs, as well as 2015 Trade Promotion Authority legislation, contemplate the incorporation of an appellate mechanism into U.S. IIAs. Moreover, while the United States has argued in the UNCITRAL Working Group III forum that states should rely on existing mechanisms that allow states to provide binding and nonbinding interpretations of IIAs, ${ }^{281}$ these instruments have existed since NAFTA entered into force, ${ }^{282}$ and have not resolved the legitimacy crisis that international investment law faces.

To satisfy the E.U. and U.S. positions, as detailed in Sections I.B and I.C, the most workable mandate for appellate review would be one that focuses only on correcting legal errors made by ad hoc arbitration tribunals, not on promoting coherence in ISDS jurisprudence. Ad hoc tribunals, which must make sense of fact-driven proceedings and then correctly apply law to fact, may make legal errors. But aside from treaty parties issuing binding legal interpretations, ${ }^{283}$ IIAs providing for ad hoc arbitration do not contain

280 See, e.g., ICSID Convention, supra note 5, art. 57 (enabling a litigant to seek to disqualify an arbitrator on the basis that the arbitrator lacks independence, among other necessary qualities).

281 U.S. Working Group III Statements, supra note 206, at 14:32:02-14:37:30 (“[E]xisting tools, such as non-disputing party submissions and joint interpretations, should definitely be included and be pursued actively.").

282 See NAFTA, supra note 40, art. 1128 ("On written notice to the disputing parties, a Party may make submissions to a Tribunal on a question of interpretation of this Agreement."); id. art. 1131(2) ("An interpretation by the [NAFTA Free Trade] Commission of a provision of this Agreement shall be binding on a Tribunal established under this Section.").

283 The joint interpretation of NAFTA Article 1105(1) by Canada, Mexico, and the United States, discussed in subsection I.C.1, see supra note 152 and accompanying text, is an example of treaty parties issuing a binding interpretation of a treaty provision. 
mechanisms to correct legal errors committed by tribunals. ${ }^{284}$ Moreover, binding treaty party interpretations do not resolve the issue of incorrect legal interpretations by ad hoc tribunals, because they apply only to prospective disputes or to disputes in which an award has not yet been issued, and because they require the treaty parties themselves to agree on the correct legal interpretation of a substantive provision to meaningfully influence interpretation of the pertinent treaty.285 And even if the European Union and the United States disagree over the role of an appellate mechanism in promoting coherence in jurisprudence, they seem to agree that appellate mechanisms are useful in correcting serious legal errors made by first-instance tribunals in international economic law. 286

Building on this logic, this Comment proposes the creation of an appellate mechanism that is formally based within ICSID. To be clear, this Comment is not the first work to propose an appellate mechanism generally or one within ICSID specifically. As discussed in subsection I.C.1, the U.S. 2004 and 2012 Model BITs provide for the possibility of an appeals mechanism. Within the context of UNCITRAL's Working Group III, several states have raised the possibility of an appeals mechanism as a more flexible alternative to the European

284 Under the USMCA, parties may seek the annulment of an award issued by an ad hoc arbitration panel. See USMCA, supra note 195, annex 14-D art. 14.D.13.9(a) (providing that a party may not seek enforcement of a final award until annulment proceedings have completed, if those proceedings have been requested). But annulment results in the invalidation of an award, not in the correction of a legal error. See CHRISTOPH SCHREUER, LORETTA MALINTOPPI, AUGUST REINISCH \& ANTHONY SINCLAIR, THE ICSID CONVENTION: A COMMENTARY 901 (2d ed. 2009) ("[T]he result of a successful application for an annulment is the invalidation of the original decision.").

285 See, e.g., USMCA, supra note 195, annex 14-D art. 14.D.9.2 ("A decision of the Commission on the interpretation of a provision of this Agreement under Article 30.2 (Functions of the Commission) shall be binding on a tribunal, and any decision or award issued by a tribunal must be consistent with that decision."). USMCA Article 30.3 explains that Commission decisions are taken by consensus - that is, Canada, Mexico, and the United States must agree on a decision for it to constitute an authoritative interpretation of the USMCA by the Commission. USMCA, supra note 195, art. 30.3.

286 Compare European Union, Possible Reform, supra note 56, ๆ 43 ("An appeal mechanism will ensure correctness. It will do this by reviewing the legal correctness of the decisions taken at first instance and by correcting any legal errors." (emphasis added)), with REPORT ON THE APPELLATE BODY, supra note 215 , at 38, 120 (explaining that "WTO Members agreed in the DSU to expressly limit the authority of the Appellate Body to review a panel's legal findings, not its factual findings," and therefore that " $[t]$ he Appellate Body was intended by negotiators as a check in the rare event a panel report contained an egregious [legal] error" (emphasis added)). 
Union's proposed Multilateral Investment Court.287 And, in 2004, ICSID itself published a white paper exploring the concept of an appeals facility. 288

Instead, the novelty of this Comment's appeals concept is twofold. First, it proposes a particular hybrid dispute settlement structure within an E.U.U.S. IIA that corresponds to the boundaries within which the European Union and United States can negotiate.289 Second, it recognizes and incorporates the inextricable relationship between international investment law and international trade law. ${ }^{290}$ For example, this Comment recognizes that an effective IIA between the European Union and United States must align with their respective positions on the role of appellate review at the WTO.291

As with most investor-state arbitration proceedings, appeals from investorstate arbitrations under an E.U.-U.S. IIA would require an administering institution to implement, oversee, and support appellate proceedings. In an E.U.-U.S. IIA, ICSID is the most logical institution in which to lodge an appellate mechanism for three reasons, all of which relate to ICSID's expertise and legitimacy in international investment law. First, ICSID is a well-respected multilateral institution that has already administered over 700 investor-state

287 See U.N. Comm'n on Int'l Trade L. (UNCITRAL), Possible Reform of Investor-State Dispute Settlement (ISDS): Appellate and Multilateral Court Mechanisms, U.N. Doc. A/CN.9/WG.III/WP.185, I 6 \& n.4 (Jan. 20-24, 2020) ("The suggestion for the establishment of an appellate mechanism is contained in various proposals submitted by Governments . ...").

288 See InT'L CTR. FOR SETTLEMENT InV. Disps. SECRETARIAT, POSSIble IMPROVEMENTS OF THE FRAMEWORK FOR ICSID ARBITRATION ๆ $20-23$ \& annex (2004) (noting than a common appeals mechanism would serve efficiency, economy, coherence, and consistency, and setting out the features of an appeals mechanism).

289 But see Barton Legum, Appellate Mechanisms for Investment Arbitration: Worth a Second Look for the Trans-Pacific Partnership and the Proposed EU-US FTA? in RESHAPING THE INVESTOR-STATE Dispute SetTlement SySTEM 437, 439-42 (Jean E. Kalicki \& Anna Joubin-Bret eds., 2015) (reasoning that the significant volume of bilateral FDI between the European Union and United States might justify the inclusion of an appellate mechanism in an E.U.-U.S. IIA, but not proposing the design of such a mechanism); but cf. Ana M. Lopez-Rodriguez, It Takes Two to Tango: Regional Investment Treaties and Investor Protection on Both Sides of the Atlantic, 2 EUR. INV. L. \& ARB. REV. 412, 442-43 (2017) (analyzing U.S. and E.U. positions on ISDS in T-TIP in 2017, including the positions of civil society and different governmental actors on both sides of the Atlantic, but not proposing a structure for an investment chapter in an E.U.-U.S. FTA).

290 To be clear, at least two articles have examined the WTO's Appellate Body as a model for an appellate mechanism for international investment law. See Mark Huber \& Greg Terpak, The WTO Appellate Body: Viability as a Model for Investor-State Dispute Settlement Mechanism, 32 ICSID REV. 545, 545 (2017); van den Broek \& Morris, supra note 254, at 35-89. Presumably because both articles were published in 2017, however, neither examined the viability of modeling an ISDS appeals mechanism on the WTO's Appellate Body in light of the United States' recent, assiduous criticism of the Appellate Body, culminating in the Appellate Body's collapse, as discussed in supra Section I.C.

291 See supra subsection I.C.4. 
disputes 292 and over one hundred annulment proceedings. ${ }^{293}$ Indeed, it is the only arbitral institution devoted exclusively to investor-state arbitration. ${ }^{294} \mathrm{It}$ also has a Secretariat comprising roughly seventy staff members. ${ }^{295}$

Second, Article 13(1) of the ICSID Convention already authorizes each ICSID Member State to nominate four arbitrators to ICSID's Panel of Arbitrators, from which parties to a dispute can choose in appointing arbitrators, ${ }^{296}$ and from which the Chair of ICSID's Administrative Council must choose when he or she needs to appoint tribunal chairs297 or annulment committees. ${ }^{298}$ Thus, with respect to this Comment's proposed appellate mechanism, ICSID has a model on which to build in determining how to develop a pool of adjudicators from which the parties, or the Chair of the Administrative Council if necessary, can draw in composing an appellate tribunal to hear a given appeal.

292 INT'L CTR. FOR SETTLEMENT INV. Disps., THE ICSID CASELOAD-STATISTICS 7 (2020) ("As of June 30, 2020, ICSID had registered 768 cases under the ICSID Convention and Additional Facility Rules.").

293 Id. at 16 chart 12 . I calculated the total number of ICSID-administered annulment proceedings by adding together the "Number of decisions rejecting the application for annulment," the "Number of decisions annulling the award in part or in full," and the "Number of annulment proceedings discontinued."

294 Other international arbitration institutions, administer both investor-state arbitration disputes and international commercial arbitration disputes, such as the Stockholm Chamber of Commerce, or administer both investor-state and other public international law disputes, such as the Permanent Court of Arbitration. Compare Dispute Resolution Services, ARB. INST. OF THE STOCKHOLM CHAMBER OF COM. https://sccinstitute.com/our-services [https://perma.cc/KB9P${ }_{5} \mathrm{RAF}$ ] (providing dispute resolution services to "Swedish and international parties" and business communities), with Dispute Resolution Services, PERMANENT CT. OF ARB., https://pcacpa.org/en/services [https://perma.cc/G7SQ-ASXG] ("The PCA provides administrative support in international arbitrations involving various combinations of states, state entities, international organizations and private parties."); see also Albert Jan van den Berg, Appeal Mechanism for ISDS Awards: Interaction with the New York and ICSID Conventions, 34 ICSID REV. 156, 188 (2019) ("If an appeal mechanism is to be established, it seems that the ICSID Convention is the preferred legal platform for building the mechanism, mainly because it is a treaty dedicated to investment arbitration and does not involve supervision and interference by national courts in enforcement and setting aside proceedings.").

295 Secretariat-Overview, INT'L CTR. FOR SETTLEMENT OF INV. DISPS., https://icsid.worldbank.org/about/secretariat [https://perma.cc/M4 $\mathrm{F}_{3-9} \mathrm{X}_{7} \mathrm{~F}$ ].

296 ICSID Convention, supra note 5, arts. 13(1), 40.

297 See id. art. 40(1) ("Arbitrators may be appointed from outside the Panel of Arbitrators, except in the case of appointments by the Chairman pursuant to Article 38."); id. art. 38 (providing that the Chairman of the Administrative Council will select a tribunal president when the parties cannot agree on one); International Centre for Settlement of Investment Disputes Rules of Procedure for Arbitration Proceedings (Arbitration Rules) 4 (providing the procedure for the Chairman of the Administrative Council to appoint the president of a tribunal when parties to the arbitration cannot agree on the president).

298 ICSID Convention, supra note 5, art. 52(3) ("On receipt of the request [for annulment] the Chairman shall forthwith appoint from the Panel of Arbitrators an ad hoc Committee of three persons."). 
Third, ICSID already serves as the Secretariat for disputes that arise under the European Union's IIAs that include the Investment Court System,299 and investors bringing ISDS claims under the USMCA may select ICSID as an administering authority. ${ }^{300}$ Thus, the prospect of adding an appellate mechanism to ICSID is not a quantum leap from the current E.U. and U.S. ISDS positions, as reflected in their recently concluded IIAs and model negotiating texts.

The mechanics of establishing an appellate mechanism at ICSID to which disputes arising out of an E.U.-U.S. IIA could be appealed would involve initiatives on at least three fronts, which are described below.

i. The Opt-In Appellate Instrument Establishing the Appellate Mechanism at ICSID

First, the European Union and United States would work with ICSID to develop a new, opt-in legal instrument enabling parties to appeal investorstate disputes that were originally administered by ICSID. Creating an optin legal instrument is a more pragmatic option than amending the ICSID Convention, which requires the unanimous consent of all ICSID Member States. ${ }^{301}$ The creation of an opt-in instrument, by contrast, would require only the parties opting into the instrument to ratify it and would technically involve a modification of the ICSID Convention between the states ratifying the instrument. ${ }^{302}$ Indeed, because the opt-in instrument would not require an amendment of the ICSID Convention, ${ }^{303}$ the mechanism could begin

299 INT'L CTR. FOR SETTLEMENT OF INV. DISPS., ANNUAL REPORT 3 (2018) (“We are very pleased that ICSID has been named as the Secretariat for the investment dispute settlement mechanisms in the recent agreements between the European Union, and Canada, Mexico and Singapore, respectively, and look forward to supporting other States in such endeavors.").

300 USMCA, supra note 195, art. 14.D.3.4(a)-(b).

301 ICSID Convention, supra note 5, art. 66(1) (providing that an amendment shall become effective only after "all Contracting States have ratified, accepted or approved the amendment").

302 See, e.g., van den Berg, supra note 294, at 170 (reasoning that an instrument allowing ICSID members to modify the Convention between them would not contravene Article 41(1)(b) of the Vienna Convention on the Law of Treaties, which governs the modification of multilateral treaties

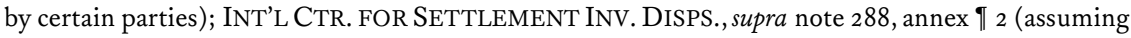
that the submission of an award to an appellate mechanism is "based on the provisions of a treaty," then the treaty providing for the ICSID appellate mechanism could "modify the ICSID Convention to the extent required, as between the States parties to that treaty").

303 At least one scholar disagrees that such an instrument would be consistent with ICSID. See N. Jansen Calamita, The (In)Compatibility of Appellate Mechanisms with Existing Instruments of the Investment Treaty Regime, 18 J. WORLD INV. \& TRADE 585, 604-13 (2017). Calamita argues that an appellate mechanism is incompatible with the ICSID Convention, because Article 41 of the Vienna Convention permits the modification of a treaty if, and only if, the treaty expressly permits such a modification or does not prohibit such a modification. Id. at 606-07. Further, Calamita emphasizes that Article 53(1) of the ICSID Convention provides that an "award [issued in an arbitration administered by ICSID] shall be binding on the parties and shall not be subject to any appeal or to any 
operating with just the European Union and United States as parties, and allow other states to join the instrument over time.

The opt-in instrument would need to cover several core issues. First, it would need to address whether, in the case of bifurcated proceedings, jurisdictional awards could be appealed, or whether only awards on the merits could be appealed. ${ }^{304}$ Because jurisdictional awards can dispose entirely of an investor-state proceeding, this Comment argues that jurisdictional awards should be appealable, just as jurisdictional awards may be annulled under the ICSID Convention. 305

Second, the instrument would need to provide the grounds of review on appeal and the actions that an appellate tribunal could take with respect to a given appeal. CETA empowers the Appellate Tribunal constituted under that treaty's Investment Court System to uphold, modify, or reverse first-instance

other remedy except those provided for in this Convention." Id. at 608. As van den Berg explains, however, neither Article 53 nor any other article of the ICSID Convention prohibits the parties from modifying the ICSID Convention within the meaning of Article 41(1)(b) of the Vienna Convention. Van den Berg, supra note 294, at 170. For the modification to be valid under Article 41(1)(b) of the Vienna Convention, the modification must (i) "not affect the enjoyment by the other parties of their rights under the treaty or the performance of their obligations" and (ii) "not relate to a provision, derogation from which is incompatible with the effective execution of the object and purpose of the treaty as a whole." VCLT, supra note 159, art. 41(1)(b). A modification of ICSID Convention Article 53 to allow for the appeal of an ICSID award satisfies these criteria because other parties' rights would not be prejudiced by the appeal of an award between two parties, and because the appeal of an award is not incompatible with the object and purpose of the ICSID Convention, as the appeal would still result in a final award and "may actually increase the legitimacy of ISDS"). Van den Berg, supra note 282 , at 170 .

304 In international arbitration, institutional rules will often permit tribunals to bifurcate a proceeding into a jurisdictional phase and a merits phase. See, e.g., International Centre for Settlement of Investment Disputes Rules of Procedure for Arbitration Proceedings (Arbitration Rules) 41(4) (explaining that tribunals may determine whether to decide jurisdictional objections as preliminary questions - that is, to bifurcate the jurisdictional objections - or to join the jurisdictional objections to the merits of the arbitration). The bifurcation of a dispute may enable the tribunal to exercise judicial economy, as a valid jurisdictional objection would obviate the need for the merits phase of the arbitration. See Marinn Carlson \& Patrick Childress, Bifurcation in Investment Treaty Arbitration, in THE INVESTMENT TREATY ARBITRATION REVIEW 48, 50 (Barton Legum ed., 4th ed. 2019) ("Procedural efficiency-whether bifurcation is more likely to increase or decrease the time and costs associated with the arbitration-is the overarching factor that tribunals consider when deciding bifurcation applications.").

305 See International Centre for Settlement of Investment Disputes Rules of Procedure for Arbitration Proceedings (Arbitration Rules) 52 (referring to the right of either party to an ICSIDadministered arbitration to request annulment of "an award," without qualifying the type of award for which the request may be submitted); Industria Nacional de Alimentos, S.A. \& Indalsa Perú, S.A. v. The Republic of Peru, ICSID Case No. ARB/o3/4, Decision on Annulment, If 130 (Sept. 5, 2007), https://www.italaw.com/sites/default/files/case-documents/ita0277.pdf [https://perma.cc/NBP7HQHR] (reviewing and denying an application for the annulment of an award issued by a tribunal that declined jurisdiction over the investor's claim). 
tribunal legal conclusions, 306 which mirrors the power given to the WTO's Appellate Body 307 and appears sensible for the purpose of this Comment's proposed structure. More controversial is CETA's empowerment of its Appellate Tribunal to uphold, modify, or reverse "manifest errors in the appreciation of the facts, including the appreciation of relevant domestic law,"308 an authority not explicitly granted to the WTO's Appellate Bodyand that the United States insists is not implicitly granted to it. ${ }^{309}$ Thus, to gain U.S. approval, the appellate instrument should not empower appellate tribunals constituted under the ICSID appellate mechanism to review "manifest errors in the appreciation of the facts." Finally, to gain U.S. endorsement, the appellate instrument should provide that, although appellate decisions might serve as persuasive authority in future disputes, they would not bind future ad hoc or appellate tribunals to follow their interpretations of the same legal issues. More specifically, to placate the United States, such a provision should ensure that the appellate mechanism would not reincarnate the WTO's Appellate Body's emphasis on creating a de facto system of precedent. 310 Such a provision might read as follows:

Under this instrument, appellate decisions interpreting a provision of a covered treaty shall not bind future appellate or ad hoc tribunals interpreting the same provision of the same treaty. The treaty parties reserve the exclusive right to adopt binding interpretations of the covered treaty's provisions. For the avoidance of doubt, however, appellate interpretations of a given treaty's provisions may be relied on as persuasive authority in subsequent disputes arising under that treaty. 311

306 CETA, supra note 14, art. 8.28.2(a) ("The Appellate Tribunal may uphold, modify or reverse a Tribunal's award based on: (a) errors in the application or interpretation of applicable law ....”).

307 See DSU, supra note 216, art. 17.13 ("The Appellate Body may uphold, modify or reverse the legal findings and conclusions of the panel.").

308 CETA, supra note 14 , art. 8.28.2(b).

309 REPORT ON THE APPELLATE BODY, supra note 215, at 38 ("WTO Members agreed in the DSU to expressly limit the authority of the Appellate Body to review a panel's legal findings, not its factual findings. Indeed, it is difficult to see how the language of Article 17.6 of the DSU could be clearer on this point ....").

310 See supra subsection I.C.4 (explaining the U.S. criticism that the Appellate Body unjustifiably created a system of de facto stare decisis).

311 As explained in subsection I.C.4, the United States endorses citing prior WTO Appellate Body reports as persuasive, not mandatory, authority. The proposed language here resembles existing language in the 2012 Model BIT that applies to ad hoc tribunals, which provides: "An award made by a tribunal shall have no binding force except between the disputing parties and in respect of the particular case." 2012 U.S. Model BIT, supra note 25, art. 34.4. 
ii. The Pool of Appellate Adjudicators

On the second front necessary to enable the appeal of investor-state disputes arising out of an E.U.-U.S. IIA, ICSID would need to establish a body of adjudicators available to hear disputes appealed to the appellate mechanism. The procedure for selecting these adjudicators could borrow from the process and criteria that ICSID uses when the Chair of the Administrative Council designates arbitrators to serve on the Panel of Arbitrators.312 For example, the Chair of the Administrative Council could designate adjudicators to serve on an appeals mechanism roster, with a mandate to ensure that those adjudicators each had demonstrated expertise in international investment law and collectively constituted a diverse group, measured across dimensions such as gender, geography, and race.313 Having the Chair of the Administrative Council establish the roster of adjudicators available to hear appeals would enhance the legitimacy of the appellate system, because it would deflect criticisms that the pool was being stacked with pro-investor or pro-state adjudicators. At the same time, however, each investor and state litigant in a particular dispute would be able to nominate an adjudicator from that pool to hear the appeal, ensuring that the appellate system would maintain the principle of neutrality throughout the arbitration's proceeding, and thus avoiding the risk of politicizing the dispute. As with ICSID-administered ad hoc arbitration proceedings, if the parties failed to agree on the appellate tribunal president, the Chair of the Administrative Council would appoint the tribunal president. 314

\section{iii. The E.U.-U.S. IIA Language}

The third front of developing the E.U.-U.S. IIA appellate procedure would involve drafting treaty language enabling investors to submit ISDS disputes to ICSID's appellate mechanism. Specifically, the E.U.-U.S. IIA would require that ad hoc arbitrations arising under the IIA be administered exclusively by ICSID and restrict appeal of those arbitrations only to the ICSID appellate mechanism. Creating such a procedure would not mark a dramatic departure from the structure of the 2012 U.S. Model BIT or the

312 ICSID Convention, supra note 5, art. 13(2) ("The Chairman may designate ten persons to each [of the Panel of Conciliators and the Panel of Arbitrators.] The persons so designated to a Panel shall each have a different nationality.").

313 See, e.g., UNCITRAL, supra note 287, I 56 ("Mechanisms should be used to ensure both geographical and gender diversity.").

314 See ICSID Convention, supra note 5, art. 38 (explaining that if the parties to an ad hoc arbitration do not agree on the composition of a tribunal within ninety days after ICSID has registered the request for arbitration, the Administrative Council Chair shall complete the tribunal's composition). 
IIAs that the European Union has recently concluded that include the Investment Court System.

Consider the 2012 Model BIT first. Article 28.10 of the 2012 Model BIT provides the following: "In the event that an appellate mechanism for reviewing awards rendered by investor-State dispute settlement tribunals is developed in the future under other institutional arrangements, the Parties shall consider whether awards rendered under Article 34 should be subject to that appellate mechanism." 315 Article 34, in turn, addresses the remedies that arbitral awards may provide and the mechanics of enforcing an award. Article 34.6(a) provides that disputing parties may not seek to enforce an ICSID award until 120 days from when the award was rendered or, if applicable, the date when annulment proceedings have completed.316 Given Article 28's explicit contemplation of an appellate mechanism being created and affecting Article 34, Article 34 should be amended to provide that disputing parties cannot seek to enforce an award issued by an ad hoc tribunal until both the disputing parties have waived their rights to appeal the award, or, if one party has appealed the award, until the appellate tribunal has issued a final decision on the award.317

Next consider the European Union's current IIA model, as exemplified by CETA. CETA Article 8.28 addresses the establishment of an Appellate Tribunal, as supported by the CETA Joint Committee, 318 which comprises representatives from Canada and the European Union. ${ }^{319}$ That article could easily be amended to provide for an appellate mechanism that is instead supported and managed by ICSID, not the CETA Joint Committee. Indeed, CETA already provides for ICSID to serve as the Secretariat for firstinstance tribunals under its Investment Court System. ${ }^{320}$

How the text in CETA and the U.S. Model BIT would be merged in an E.U.-U.S. IIA is beyond the scope of this Comment; the point is that the United States and European Union have treaty language that could be modified to permit disputing parties to submit appeals to an appellate mechanism within ICSID.

3152012 U.S. Model BIT, supra note 25, art. 28.10.

$316 I d$. art 36.4(a).

317 Id. art. 28.10. Under Article 34, exhaustion of an appellate right would presumably mean the issuance of a decision by an appellate tribunal constituted under ICSID's appellate mechanism.

318 See CETA, supra note 14, art. 8.28.7 ("The CETA Joint Committee shall promptly adopt a decision setting out the following administrative and organisational matters regarding the functioning of the Appellate Tribunal ....").

319 CETA, supra note 14, art. 26.1.1 ("The Parties hereby establish the CETA Joint Committee comprising representatives of the European Union and representatives of Canada. The CETA Joint Committee shall be co-chaired by the Minister for International Trade of Canada and the Member of the European Commission responsible for Trade, or their respective designees.").

$320 I d$. art. 8.27.16 ("The ICSID Secretariat shall act as Secretariat for the Tribunal and provide it with appropriate support."). 
iv. The Appellate Mechanism Illustrated

To illustrate how this system would work, suppose that an E.U. investor initiated investor-state arbitration against the United States and selected ICSID as the arbitral institution to administer the ad hoc arbitration. Suppose, further, that the ad hoc tribunal issued an award, and that award contained what either the United States or the investor perceived was a legal error. The party claiming a legal error would then invoke the ICSID appellate instrument and the pertinent provisions of the E.U.-U.S. IIA, specify the legal grounds on which it believed the ad hoc tribunal erred, and submit a request for appellate review to ICSID. ${ }^{321}$ The parties would then select adjudicators from the ICSID-managed roster of appellate adjudicators. Those adjudicators would constitute the appellate tribunal, which would review the claimed legal errors and issue a final, binding, non-reviewable decision to the parties on those legal issues. The original award, as modified by the appellate tribunal's legal conclusions, would then be enforceable.

\section{Substantive Provisions}

The second main criticism leveled against international investment law is that IIAs' substantive standards-the provisions creating protections for foreign investors and obligations for host states-undermine states' right to regulate. 322 More specifically, critics argue that broadly defined investment protection standards in IIAs deter states from enacting certain public policy measures out of fear that foreign investors will challenge those measures as breaching a pertinent IIA's substantive obligations. ${ }^{323}$ An IIA between the European Union and the United States therefore presents an opportunity to establish precise substantive standards that simultaneously provide more ex ante certainty about the scope of those standards and preserve states' regulatory space.

321 To prevent disputing parties from unnecessarily delaying the resolution of the dispute, the IIA would prevent the United States, the European Union, and their investors from seeking the annulment of an award. In other words, the IIA would force disputing parties to raise all their legal claims in one appeal.

322 See, e.g., Colin Brown, Deputy Head of Unit, Disp. Settlement \& Legal Aspects of Trade Poly, Directorate General for Trade, Eur. Comm'n, The European Union's Approach to Dispute Settlement 3 (June 22, 2018), https://trade.ec.europa.eu/doclib/docs/2018/july/tradoc_157112.pdf [https://perma.cc /E6XD-M8S9] ("Much of the criticism of the investment protection and ISDS system comes from the concern that it is a system which impacts and limits genuine regulatory activities.").

323 See, e.g., U.N. CONF. ON TRADE \& DEV., FAIR AND EQUiTABLE TREATMENT: UNCTAD SERIES ON ISSUES IN INTERNATIONAL INVESTMENT AgREEMENTS II, at xiii, U.N. Doc. UNCTAD/DIAE/IA/2011/5, U.N. Sales No. E.11.II.D.15 (2012) ("[T] he application of [investment protection] provisions has brought to light the need to balance investment protection with competing policy objectives of the host State, and in particular, with its right to regulate in the public interest."). 
This Comment uses the most controversial and expansive substantive standard-fair and equitable treatment ${ }^{324}$-as an example of how the European Union and United States should reconcile their positions on core substantive provisions in an IIA. Although the FET standard's wording varies by treaty, its basic content remains the same: to provide fair and equitable treatment to investments made by investors of the treaty's counterparty. ${ }^{325}$ For example, CETA provides that "[e]ach Party shall accord in its territory to covered investments of the other Party and to investors with respect to their covered investments fair and equitable treatment." 326 Similarly, the USMCA provides that "[e]ach Party shall accord to covered investments treatment in accordance with customary international law, including fair and equitable treatment." 327 Nonetheless, the treaties diverge on how that general standard is further defined; this Comment proposes a reconciliation of those positions.

\section{a. E.U. and U.S. Formulations of the Fair and Equitable Treatment Standard in Existing International Investment Agreements}

Although the United States and the European Union share concerns about expansive interpretations of the FET standard, they have taken different approaches to narrowing its scope. The European Union has attempted to clarify and tighten the standard by including a "closed list" of sufficient conditions for a FET breach. ${ }^{328}$ For example, CETA Article 8.10.2 provides:

324 See, e.g., id. at 1 ("The fair and equitable treatment (FET) standard is a key element in contemporary international investment agreements (IIAs). Over the years, it has emerged as the most relied upon and successful basis for IIA claims by investors."). Therefore, the U.N. Conference on Trade and Development has expressed concern "that the FET standard may be applied in investor-State arbitration to restrict host-country administrative and governmental action to a degree that threatens the policymaking autonomy of that country." Id.; see also Sykes, supra note 30, at 529 ("The exact phrasing of the [FET] obligation varies [across IIAs], but it inevitably exhibits considerable vagueness.").

325 See U.N. CONF. ON TRADE \& DEV., supra note 323, at xiii ("[M]any tribunals have interpreted [FET provisions] broadly to include a variety of specific requirements including a State's obligation to act consistently, transparently, reasonably, without ambiguity, arbitrariness or discrimination, in an evenhanded manner, to ensure due process in decision-making and respect investors' legitimate expectations.").

326 CETA, supra note 14, art. 8.10.1.

327 USMCA, supra note 195, art. 14.6.1.

328 See, e.g., Council Meeting Document DS 1744/12, EU Canada Comprehensive Economic and Trade Agreement-Landing Zones 9 (Nov. 6, 2012), https://www.lapresse.ca/html/ 1633/Document_UE_2.pdf [https://perma.cc/42JU-JQ3 M] (noting that a "possible solution" to the European Union's reluctance to tie the FET standard to customary international law "could be to spell out the criteria for [the FET standard's] application, thereby codifying a generally accepted outcome of jurisprudence that both sides are comfortable with"); SIMON LESTER \& BRYAN MERCURIO, SAFEGUARDING POLICY SPACE IN INVESTMENT AGREEMENTS 3 (2017), https:/www.cato.org/ sites/cato.org/files/articles/lester-mercurio-iiel-issue-brief-december-2017.pdf [https://perma.cc/ 
A Party breaches the obligation of fair and equitable treatment ... if a measure or series of measures constitutes:

(a) denial of justice in criminal, civil or administrative proceedings;

(b) fundamental breach of due process, including a fundamental breach of transparency, in judicial and administrative proceedings;

(c) manifest arbitrariness;

(d) targeted discrimination on manifestly wrongful grounds, such as gender, race or religious belief;

(e) abusive treatment of investors, such as coercion, duress and harassment; or

(f) a breach of any further elements of the fair and equitable treatment obligation adopted by the Parties in accordance with paragraph 3 of this Article. 329

In other words, CETA's FET standard provides five independent grounds on which state measures may breach the FET standard, as well as the option to add to that set of grounds. These grounds require egregious state conduct to constitute a breach, as indicated by the adjectives "fundamental," "manifest," "targeted," and "abusive," and therefore establish a high standard for a breach to occur.330 At the same time, they provide a measure of certainty about what conduct will breach the FET standard, which advantages investors and states alike.

By contrast, U.S. IIAs provide simply that the FET standard means the minimum standard of treatment guaranteed to aliens under customary international law.331 U.S. IIAs explain that, under customary international law, the FET obligation "includes the obligation not to deny justice in criminal, civil, or administrative adjudicatory proceedings in accordance with the principle of due process embodied in the principal legal systems of the world." 332 Unlike CETA, however, neither the 2012 U.S. Model BIT nor the USCMA's investment chapter provides additional guidance about what hoststate conduct breaches the FET standard. ${ }^{333}$

$\left.\mathrm{YW}_{4} \mathrm{~K}-\mathrm{AZ} 9 \mathrm{~S}\right]$ ("[T]he most recent EU investment agreements offer more specific details on the scope and meaning of FET than do past agreements.").

329 CETA, supra note 14 , art. 8.10.2.

330 See Sykes, supra note 30, at 532.

331 See, e.g., USMCA, supra note 195, art. 14.6.1 ("Each Party shall accord to covered investments treatment in accordance with customary international law, including fair and equitable treatment and full protection and security.").

3322012 U.S. Model BIT, supra note 25, art. 5.2(a); see also USMCA, supra note 195. art. 14.6.2(a) ("Fair and equitable treatment' includes the obligation not to deny justice ... . in accordance with the principle of due process embodied in the principal legal systems of the world ....").

333 Cf. UMSCA, supra note 195, art. 14.6.2 (providing only that this provision "prescribes the customary international law minimum standard of treatment of aliens as the standard of treatment to be afforded to covered investments" without providing more specific guidance). 
The CETA FET standard also diverges from the USMCA FET standard in that it incorporates the "legitimate expectations" principle, which is often viewed as forming a component of the FET standard in international investment law. ${ }^{334}$ As a general proposition, the legitimate expectations principle protects investors against host-state measures that frustrate their reasonable, investment-backed expectations. ${ }^{335}$

CETA Article 8.10.4 codifies this principle by providing that, in determining whether a respondent has breached the FET standard, a tribunal may consider whether the respondent "made a specific representation to an investor to induce a covered investment, that created a legitimate expectation, and upon which the investor relied in deciding to make or maintain the covered investment, but that the Party subsequently frustrated."336 In other words, in determining whether a host state breached the FET standard, the tribunal may account for whether the host state frustrated the investor's legitimate expectations. To some extent, CETA Article 8.9.2 constrains Article 8.10 .4 by providing that the "mere fact" that a host state measure is inconsistent with an investor's expectations does not, by itself, breach the FET standard. ${ }^{337}$ Nonetheless, Article 8.10.4 plays an important role in CETA's FET standard because it explicitly recognizes the legitimate expectations principle as a factor to consider under the FET standard and explains how a tribunal should analyze a legitimate expectations claim. ${ }^{338}$

By contrast, the USMCA does not recognize the legitimate expectations principle as a factor that tribunals should consider in assessing a breach of the FET standard. In language that parallels Article 8.9.2 of CETA, Article 14.6.4 of the USMCA provides that "the mere fact that a Party takes or fails to take an action that may be inconsistent with an investor's expectations does not constitute a breach of this Article, even if there is loss or damage to the covered investment as a result." 339 But unlike CETA's Article 8.10.4, the USMCA contains no corresponding article that instructs a tribunal on how to

334 See, e.g., U.N. CONF. ON TRADE \& DEV., supra note 323, at 63 ("Protection of investors' legitimate expectations has been repeatedly identified by arbitral tribunals as a key element of the FET standard.").

335 See, e.g., CAMPBEll Mclachlan, LAURENCE SHORE \& MATtheW Weiniger, INTERNATIONAL INVESTMENT ARBITRATION: SUBSTANTIVE PRINCIPLES $§ 7.179$ (2017) ("The doctrine of legitimate expectations is concerned with due process in administrative decision-making: ensuring the consistent application of the law and enforcing representations by the host State when these were made specifically enough to the particular investor to justify reliance.").

336 CETA, supra note 14, art. 8.10.4.

337 Id. art. 8.9.2.

338 See id. art. 8.10.4.

339 USMCA, supra note 195 , art. 14.6.4. 
account for or evaluate an investor's expectations created by a specific government representation to that investor. ${ }^{340}$

b. The Formulation of the Fair and Equitable Treatment Standard the European Union and United States Should Include in an E.U.-U.S. IIA

To maximize an E.U.-U.S. IIA's contribution to the legitimacy of international investment law and the predictability of transatlantic investment, its FET standard should (1) prescribe the conditions that constitute a breach of the FET standard, (2) incorporate the legitimate expectations principle, and (3) subject the FET standard to a general exceptions article that prescribes the conditions excusing a breach of the FET standard on public policy grounds. These proposed elements of the E.U.-U.S. IIA are explained in turn below.

\section{i. Prescribing the Sufficient Conditions for a FET Breach}

The European Union's formulation of the FET standard-prescribing the sufficient conditions for a FET breach ${ }^{341}$ - should serve as the basis for the E.U.U.S. IIA's FET standard for two reasons. First, an FET standard describing the circumstances that breach the standard would enable both parties to more confidently craft FET-consistent public policy measures. Second, it would create more ex ante certainty about the types of FET claims likely to prevail, which should result in efficiency gains for investors and states alike.

By contrast, the USMCA's linkage of its FET standard to the minimum standard of treatment under customary international law provides little ex ante certainty to investors and states about what state conduct will breach that standard. 342 While most investor-state arbitration participants and

340 See id.; cf. Patrick Dumberry, Fair and Equitable Treatment, in FOREIGN INVESTMENT UNDER THE COMPREHENSIVE ECONOMIC AND TRADE AGREEMENT (CETA) 95, 107 (Makane Moïse Mbengue \& Stefanie Schacherer eds., 2019) ("The CETA parties therefore did not follow the more radical option adopted in the Trans-Pacific Partnership (TPP) explicitly excluding legitimate expectations from the obligations covered by the FET clause."). The legitimate expectations provision in the TPPsince rebranded as the CPTPP-matches the legitimate expectations provision in the USMCA. Compare Comprehensive and Progressive Agreement for Trans-Pacific Partnership (CPTPP) art. 9.6.4, Mar. 8, 2018, https://www.mfat.govt.nz/assets/Trade-agreements/TPP/Text-ENGLISH/9.-InvestmentChapter.pdf [https://perma.cc/5JYN-R2 $\mathrm{X}_{3}$ ] ("For greater certainty, the mere fact that a Party takes or fails to take an action that may be inconsistent with an investor's expectations does not constitute a breach of this Article, even if there is loss or damage to the covered investment as a result."), with USMCA, supra note 195, art. 14.6.4 (same).

341 See supra subsection I.B.4 (explaining how CETA operates, including how the FET provision of CETA functions); supra subsection II.B.2.a (comparing the E.U. and U.S. formulations of the FET standard).

342 See, e.g., ADF Grp. Inc. v. United States of America, Case No. ARB(AF)/oo/1, PostHearing Submission, at 3 (NAFTA Arb. Trib. June 27, 2002), https://www.italaw.com/sites/default/files/case-documents/italaw8602.pdf [https://perma.cc/YJV5- 
commentators agree that customary international law guarantees a minimum standard of treatment, "what remains controversial is to determine the actual content of that standard." 343 Similarly, UNCTAD has criticized the U.S. IIA link between the FET standard and the minimum standard of treatment on the ground that "the minimum standard itself is highly indeterminate [and] lacks a clearly defined content." 344 An FET standard linked to the minimum standard of treatment therefore does not provide much clarity on the resolution of particular investment disputes, as the minimum standard of treatment "is a concept that does not offer ready-made solutions for deciding modern investment disputes; at best, it gives a rough idea of a high threshold that the challenged governmental conduct has to meet for a breach to be established." 345 For example, although the USMCA provides that the FET obligation under the minimum standard of treatment includes the obligation not to deny justice "in accordance with the principle of due process embodied in the principal legal systems of the world," 346 this broad language does not illuminate the circumstances that will result in a denial of justice, or that will otherwise breach the FET standard. ${ }^{347}$

Indeed, tribunals have routinely struggled with how to interpret the FET standard under U.S. IIAs tying FET to the minimum standard of treatment, especially given that the minimum standard of treatment developed in the early twentieth century. ${ }^{448}$ For example, the tribunal in Mondev v. United States reasoned that FET under customary international law must reflect "the evolutionary character of international law" and, in the context of a modern investor-state dispute, could not refer to the standard espoused by the Mexican Claims Commission in the 1926 United States Neer v. Mexico casethe case to which the minimum standard of treatment is often traced. 349

GQNW] ("The rules encompassed within the customary international law minimum standard of treatment are specific ones that address particular contexts. There is no single standard applicable to all contexts." (internal citations omitted)).

343 DUMBERRY, supra note $41, \S 1.01[\mathrm{E}]$.

344 U.N. CONF. ON TRADE \& DEV., supra note 323, at 28.

$345 \mathrm{Id}$. at 46.

346 USCMA, supra note 195, art. 14.6.2(a).

347 See DUMBERRY, supra note 41, § 1.01[E] ("The 2012 UNCTAD report merely indicates that '[the minimum standard of treatment] is often understood as a broad concept intended to encompass the doctrine of denial of justice along with other aspects of the law of State responsibility for injuries to aliens.") (quoting U.N. CONF. ON TRADE \& DEV., supra note 323, at 44).

348 See id. $\S 1.01[\mathrm{~A}]$ ("Despite a strong opposition by many States, the early twentieth century nevertheless saw the gradual emergence of a minimum standard of treatment.").

349 Mondev Int'l Ltd. v. United States of America, ICSID Case No. ARB(AF)/99/2, Award, I ๆ 114-16, 119 (Oct. 11, 2002), https://www.italaw.com/sites/default/files/case-documents/ita1076.pdf [https://perma.cc/SR8U-D4JX]; DUMBERRY, supra note 41, §1.01[B] ("The Neer case has had considerable influence on the emergence of the concept of a minimum standard of treatment."). The tribunal in the Neer case reasoned that for the international minimum standard of treatment accorded to aliens to be breached, the host state's actions needed to "amount to an outrage, to bad 
Instead, according to the Mondev tribunal, NAFTA's FET standard must "incorporate current international law, whose content is shaped by the conclusion of more than two thousand bilateral investment treaties." 350 In other words, since the minimum standard of treatment was expounded in the early twentieth century, its content must have evolved. 351

But tribunals have struggled to determine the minimum standard's precise contemporary content - that is, how the minimum standard of treatment has evolved. Recently, NAFTA tribunals have followed an approach that acknowledges that NAFTA's provision containing the FET standard, Article 1105(1), refers to the minimum standard but then frames the minimum standard by reference to how prior NAFTA tribunals have interpreted Article 1105(1).352 In other words, they have not required claimants to adduce evidence of widespread state practice and opinio juris - the two elements necessary to establish a rule of customary international law353 - even though claimants in investor-state arbitration bear the burden of establishing the content of the minimum standard. ${ }^{354}$ The tribunal in Windstream Energy LLC v. Canada demonstrated why tribunals have followed this approach:

The Tribunal further agrees with the Respondent that in principle the content of a rule of customary international law such as the minimum standard of treatment can best be determined on the basis of evidence of actual State practice establishing custom that also shows that the States have

faith, to wilful neglect of duty, or to an insufficiency of governmental action so far short of international standards that every reasonable and impartial man would readily recognize its insufficiency." Neer v. United Mexican States, 4 R.I.A.A. 6o, 61-62 (Gen. Claims Comm'n 1926).

350 Mondev, 『1 125.

351 See, e.g., ADF Grp. Inc. v. United States of America, Case No. ARB(AF)/oo/1, Award, \ 179 (NAFTA Arb. Trib. Jan. 9, 2003), https://www.italaw.com/sites/default/files/casedocuments/itaooo9.pdf [https://perma.cc/J48R-ZAKX] ("[W]hat customary international law projects is not a static photograph of the minimum standard of treatment of aliens as it stood in 1927 when the Award in the Neer case was rendered.").

352 See, e.g., Clayton v. Gov't of Can., PCA Case No. 2009-04, ๆ 442-46 (NAFTA Arb. Trib. Mar. 17, 2015), https://www.italaw.com/sites/default/files/case-documents/italaw4212.pdf [https://perma.cc/ J9JB-YLQ2] (embracing the interpretation of Article 1105(1) articulated by the tribunal in Waste Management, Inc. v. Mexico, that the minimum standard is breached by "conduct [that] is arbitrary, grossly unfair, unjust or idiosyncratic, is discriminatory and exposes the claimant to sectional or racial prejudice, or involves a lack of due process leading to an outcome which offends judicial propriety") (quoting Waste Mgmt., Inc. v. United Mexican States, ICSID Case No. ARB(AF)oo/3, Award, ๆף 98-99 (Apr. 30, 2004), https://www.italaw.com/sites/default/files/case-documents/itaogoo.pdf [https://perma.cc/G7F9-XCFX]).

353 See, e.g., USMCA, supra note 195, annex 14-A (defining customary international law with these two elements).

354 See PATRICK Dumberry, The Formation AND IDENTIFICATION OF Customary INTERNATIONAL LAW IN INTERNATIONAL INVESTMENT LAW 39 (2016) ("One of the basic principles of international law is that the burden of proving ... a rule of customary international law rests on the party that alleges it. ... Investor-State arbitration tribunals have also held that a customary rule needs to be proven by the party that alleges it."). 
accepted such practice as law (opinio juris). However, the Tribunal notes that neither Party has produced such evidence in this arbitration. In the circumstances, the Tribunal must rely on other, indirect evidence in order to ascertain the content of the customary international law minimum standard of treatment; the Tribunal cannot simply declare non liquet. Such indirect evidence includes, in the Tribunal's view, decisions taken by other NAFTA tribunals that specifically address the issue of interpretation and application of Article 1105(1) of NAFTA, as well as relevant legal scholarship.355

The Windstream tribunal's analysis illustrates that disputing parties rarely undertake the monumental task of adducing the evidence of (1) widespread state practice and (2) opinio juris necessary to establish the content of the minimum standard of treatment under customary international law; instead, they tend to rely on prior tribunals' interpretations of the standard, NAFTA members' non-disputing party submissions, restatements, and scholarship. 356 Tribunals then rely on the parties' briefing of the issue to determine the minimum standard of treatment's content, which means that they, too, rely on prior tribunals' interpretation of the standard.357 In turn, there is little ex ante certainty about how a given tribunal will decide an FET claim under U.S. IIAs, except that the tribunal will likely rely on nonbinding jurisprudence to give the minimum standard of treatment content and effect.

By contrast, the closed list of circumstances that will breach the FET standard under CETA provides more ex ante certainty about how the

355 Windstream Energy LLC v. Gov't of Can., PCA Case No. 2013-22, Award, ๆ 351 (NAFTA Arb. Trib. Sept. 27, 2016)., https://www.italaw.com/sites/default/files/case-documents/italaw7875.pdf [https:// perma.cc/S7DW-BPJR].

356 Id.; see, e.g., Eli Lily \& Co. v. Gov't of Can., Case No. UNCT/14/2, Claimant's Memorial, II 254-60 (NAFTA Arb. Trib. Sept. 29, 2014), https://www.italaw.com/sites/default/files/casedocuments/italaw4046.pdf [https://perma.cc/C6ZJ-WA4S] (citing prior interpretations by "NAFTA and non-NAFTA tribunals" to advance an interpretation of the minimum standard of treatment, not by adducing evidence of widespread state practice or opinio juris); Mesa Power Grp., LLC v. Gov't of Can., Memorial of the Investor, ๆ \ 336-44 (NAFTA Arb. Trib. Nov. 20, 2013), https://www.italaw.com/sites/default/files/case-documents/italaw3220.pdf [https://perma.cc/9XQN-MKHP] (relying on prior tribunals' interpretations of the minimum standard to reason that "it is not necessary to specifically prove the elements of practice and opinio juris," and concluding instead that "[i]nternational tribunal decisions are therefore a primary source of content of customary international law"); DUMBERRY, supra note 41, § 3.01[A] ("But how have tribunals actually used their 'creative' role in the context of the FET clause? For the most part, they have simply looked at what other tribunals have done in the past.").

357 See, e.g., Glamis Gold Ltd. v. United States of America, Award, ๆ 1 623-26 (NAFTA Arb. Trib. June 8, 2009) https://www.italaw.com/sites/default/files/case-documents/itao378.pdf [https://perma.cc/YN45-DJSD] (reviewing the claimant's and respondent's analysis of prior NAFTA awards and concluding from that review alone - that is, without identifying widespread state practice or opinio juris - that Article 1105 precludes NAFTA parties from treating foreign investors from another NAFTA party in "a manifestly arbitrary manner"); DUMBERRY, supra note 354, at 47 ("Investment tribunals have generally failed in their task of properly revealing the existence of customary rules."). 
standard will be interpreted. Moreover, this approach to the FET standarddefining the content of the FET standard more precisely-accords with the U.S. view that states should exercise control over the interpretation of substantive obligations in their IIAs. ${ }^{358}$ And CETA's formulation of the FET standard does not tilt the standard in favor of investors: the bar is high for investors to establish the existence of any of the circumstances that constitute a FET breach under CETA. 359

\section{ii. Codifying the Legitimate Expectations Principle}

Similarly, an E.U.-U.S. IIA should include CETA's formulation of the legitimate expectations principle as a factor that tribunals may consider in determining a FET breach. Before explaining why, it is necessary to address the importance of including the principle in the E.U.-U.S. IIA in the first place, especially in light of criticism that the principle infringes states' regulatory sovereignty. ${ }^{360}$

The legitimate expectations principle accounts for the fact that host states face incentives to renege on specific promises they made to induce a foreign investment after the foreign investment has been made, often to the detriment of the foreign investor. ${ }^{361}$ Indeed, tribunals have tended to find that states have frustrated investors' legitimate expectations when states have repudiated specific promises to those investors or the industry to which those investors belong. ${ }^{362}$ Thus, when properly defined and circumscribed, the legitimate expectations principle disciplines states against undermining an

358 U.S. Working Group III Statements, supra note 206, at 11:06:25-11:11:07 ("[U]ltimately . . . the duty rests on states to ensure the meaning of their . . . treaties, and that's an important duty that [the United States] would not want to necessarily delegate without careful consideration.").

359 See Sykes, supra note 30, at 532 ("Thus, if an investor is misled by the host country to [its] detriment, it must frame its claim as 'denial of justice,' 'fundamental breach of due process,' 'manifest arbitrariness,' or 'abusive treatment,' all of which suggest a fairly high standard for the investor to meet.").

360 See, e.g., David Gaukrodger, The Balance between Investor Protection and the Right to Regulate in Investment Treaties: A Scoping Paper 26 (OECD Working Papers on International Investment No. 2017/02, 2017), https://www.oecd-ilibrary.org/docserver/82786801-en.pdf?expires $=1616452501 \&$ $\mathrm{id}=\mathrm{id} \&$ accname $=$ guest $\&$ checksum $=546 \mathrm{AEABBA}_{7} \mathrm{EC}_{2} 6{ }_{5} \mathrm{~A}_{14} \mathrm{~B}_{4} \mathrm{AECoD}{ }_{74} \mathrm{BBDB} \quad$ [https:// perma.cc/ $\mathrm{KKM}_{3}-\mathrm{TN} 9 \mathrm{P}$ ] ("The question of whether and how treaties protect covered investors' legitimate expectations is an important element in many debates about the balance of the right to regulate and investor protection.").

361 See Sykes, supra note 30, at 497 ("It is widely understood in economics that once such sunk costs have been incurred, the stream of returns necessary to recoup them becomes vulnerable to various [government] actions that may appropriate all or part of the returns, often termed a 'holdup problem.").

362 See MCLACHLAN, supra note 335, $§ 7.189$ ("Thus, cases in which tribunals have found the host State in breach of the fair and equitable treatment standard on the ground of legitimate expectations have generally been where the State has made specific commitments either to the particular investor, or in the context of particular industry."). 
investor's reasonable reliance interests. ${ }^{363}$ Moreover, under a proper formulation of the legitimate expectations principle, "[a]s long as governments do not mislead investors about the likelihood of policy change, or conceal information that they could easily disclose, there is little basis for awarding compensation when investors are disappointed by a change in policy that violates no other treaty obligation." 364

CETA Article 8.10.4 provides such a proper formulation of the legitimate expectations principle. As described earlier in this subsection, CETA's formulation of the legitimate expectations principle provides that a tribunal, in assessing a potential breach of the FET obligation, may consider whether (1) the host state provided a specific representation to the investor, (2) to induce that investor's investment, (3) on which the investor relied to invest, and (4) that the host state subsequently frustrated.365 By contrast, the USMCA provides only that the "mere fact" that a host state's actions are inconsistent with an investor's expectations does not breach the minimum standard. ${ }^{366}$ Both these formulations provide that an action inconsistent with an investor's expectations does not necessarily amount to a FET breach, but the CETA provision provides more clarity because it explains when, and how, a tribunal should evaluate an investor's expectations.367 By contrast, the USMCA reference to an investor's expectations does not provide any guidance about whether, or how, a tribunal may factor an investor's expectations into its FET analysis; it states only that frustration of an investor's expectations does not breach the FET standard. ${ }^{368}$

Accordingly, CETA's formulation of the legitimate expectations principle should serve as the basis for a legitimate expectations provision in the E.U.U.S. IIA. Nevertheless, that provision should be improved to clarify that the investor's reliance on specific representations made to it by the host state must be objectively reasonable for a host state to frustrate an investor's legitimate expectations. ${ }^{369}$ As noted above, the text of CETA Article 8.10.4 requires an investor only to rely-not to reasonably rely-on a host state's specific

363 Sykes, supra note 30, at 530 ("Properly circumscribed, this interpretation of the fair and equitable treatment principle can respond effectively to a key source of inefficient risk ... the possibility that host countries can exploit conditions of asymmetric information to mislead investors about future contingencies.").

$364 \mathrm{Id}$.

365 CETA, supra note 14, art. 8.10.4; supra subsection II.B.2.a.

366 USCMA, supra note 195, art. 14.6.4.

367 See Dumberry, supra note 340, at 108 (noting that CETA Article 8.10.4 delimits the specific elements of the legitimate expectations principle).

368 USMCA, supra note 195, art. 14.6.4 ("For greater certainty, the mere fact that a Party takes or fails to take an action that may be inconsistent with an investor's expectations does not constitute a breach of this Article, even if there is loss or damage to the covered investment as a result.").

369 See DUMBERRY, supra note 340, at 108 (questioning why CETA omitted a requirement that an investor's reliance must be objectively reasonable to satisfy the legitimate expectations principle). 
representations for the investor's legitimate expectations to be frustrated. Codifying that the investor's reliance must be objectively reasonable would ensure that the IIA would not protect investors against bad business judgment.

iii. Providing for General Exceptions that Parallel Those Found in the WTO Agreements

But to fully address ISDS legitimacy concerns, the E.U.-U.S. IIA should go further than build on the CETA's formulation of the FET standard and the legitimate expectations principle; it should also provide an analytical framework for determining when the pursuit of legitimate policy objectives excuses the nonperformance of other treaty obligations, including the obligation to accord fair and equitable treatment to investments. 370

The IIA should incorporate such a framework for two reasons. First, linking the E.U.-U.S. IIA to the WTO agreements more tightly should help neuter the specious argument that IIAs uniquely constrain host-state policymaking: under the DSU, the WTO's DSB can require WTO Members to repeal domestic legislative or regulatory measures or else face countermeasures, ${ }^{371}$ whereas IIAs do not. ${ }^{372}$ The WTO has not attracted comparable scrutiny on this basis in recent years, even though, through the adoption of panel and Appellate Body reports finding breaches of the WTO

370 See U.N. CONF. ON TRADE \& DEV., UNCTAD's REFORM PACKAgE FOR THE INTERNATIONAL INVESTMENT REGIME38-42 (2018) (describing various potential public policy and national security exceptions to IIA provisions).

371 Remedies in WTO dispute settlement require offending members to modify their domestic regulations or legislation to bring them into compliance with their WTO obligations, or else face retaliation through the suspension of trade concessions. See DSU, supra note 216, art. 19.1 ("Where a panel or the Appellate Body concludes that a measure is inconsistent with a covered agreement, it shall recommend that the Member concerned bring the measure into conformity with that agreement."); id. art. 16.4 (footnote omitted) ("Within 6o days after the date of circulation of a panel report to the Members, the report shall be adopted at a DSB meeting unless a party [appeals the panel's report] or the DSB decides by consensus not to adopt the report."); id. art. 17.14 ("An Appellate Body report shall be adopted by the DSB and unconditionally accepted by the parties to the dispute unless the DSB decides by consensus not to adopt the Appellate Body report within 30 days following its circulation to the Members."); $i d$. art. 21 (providing for surveillance measures and compliance proceedings to monitor whether offending Member States have modified their laws or regulations to conform to the WTO agreements); id. art. 22 (establishing that if an offending WTO Member State "fails to bring the measure found to be inconsistent with a covered agreement into compliance or otherwise comply with the recommendations and rulings within the reasonable period of time," then the offended WTO Member State may seek compensation from the offending Member State or seek authorization from the DSB to impose countermeasures (emphasis added)); see also van den Broek \& Morris, supra note 254, at 63 (explaining that if WTO Member States fail to comply with findings that they have breached their WTO obligations, the offended members may receive authorization to impose retaliatory trade sanctions).

372 See, e.g., CETA, supra note 14, art. 8.39.1 (providing that the tribunals constituted under the treaty's Investment Court System may only award monetary damages or "restitution of property" as a remedy for treaty breaches). 
agreements, the DSB has directed WTO Members to repeal sovereign measures that infringed their WTO obligations. ${ }^{373}$

Second, the WTO agreements provide a logical framework for evaluating when public policy measures excuse performance of other treaty obligations. Although different WTO agreements offer slightly different formulations of this framework, they all provide that a Member State measure that genuinely contributes to a legitimate public policy objective may excuse noncompliance with another provision of the relevant agreement, provided that the measure is necessary to achieve that objective and that the measure does not otherwise "constitute a means of arbitrary or unjustifiable discrimination." 374 For example, Article XIV of the General Agreement on Trade in Services (GATS) provides, in relevant part, the following:

Subject to the requirement that such measures are not applied in a manner which would constitute a means of arbitrary or unjustifiable discrimination between countries where like conditions prevail, or a disguised restriction on trade in services, nothing in this Agreement shall be construed to prevent the adoption or enforcement by any Member of measures:

(a) necessary to protect public morals or to maintain public order;

(b) necessary to protect human, animal or plant life or health; [or]

373 See, e.g., Panel Report, United States—Certain Measures Relating to the Renewable Energy Sector, ף 8.4, WTO Doc. WT/DS 510/R (adopted June 27, 2019) (finding that ten different U.S. state renewable energy measures, passed by seven different states, were inconsistent with the United States' obligations under Article III:4 of the GATT 1994). To be clear, the United States has consistently protested panel and Appellate Body reports finding that U.S. trade remedy laws and regulations have breached the WTO's Antidumping Agreement and the Subsidies and Countervailing Measures Agreement. See, e.g., Press Release, Office of the U.S. Trade Representative, United States Rejects WTO Dispute Report Shielding Canada's Harmful Lumber Subsidies (Aug. 24, 2020), https://ustr.gov/about-us/policy-offices/pressoffice/press-releases/2020/august/united-states-rejects-wto-dispute-report-shielding-canadas-harmfullumber-subsidies [https://perma.cc/W645-6KFX] (quoting Ambassador Lighthizer as saying that the panel's finding in United States-Softwood Lumber VII, see Panel Report, United States-Countervailing Measures on Softwood Lumber from Canada, WTO Doc. WT/DS533/R (adopted Aug. 24, 2020), "would prevent the United States from taking legitimate action in response to Canada's pervasive subsidies for its softwood lumber industry"); Press Release, Office of the U.S. Trade Representative, USTR Robert Lighthizer Statement on the WTO Panel Report in Canada's Challenge to U.S. Countervailing Duties on Supercalendered Paper (July 6, 2018), https://ustr.gov/about-us/policy-offices/press-office/pressreleases/2018/july/ustr-robert-lighthizer-statement-wto [https:/perma.cc/XAB8-RBWY] (quoting Ambassador Lighthizer as saying that the "United States has long warned that the attack on our trade laws risks undermining the credibility of the WTO, and we again urge Members to consider the harm resulting from such rulings"). But the United States has not attacked the power conferred on the DSB by the DSU to mandate changes to WTO members' laws and regulations.

374 General Agreement on Trade in Services (GATS) art. XIV, Apr. 15, 1994, Marrakesh Agreement Establishing the World Trade Organization, Annex 1B, 1869 U.N.T.S. 183 [hereinafter GATS]; see, e.g., General Agreement on Tariffs and Trade art. XX, Oct. 30, 1947, 61 Stat. A-11, 55 U.N.T.S. 194 (permitting contracting parties to adopt and enforce measures to protect public morals and human health, among other state objectives). 
(c) necessary to secure compliance with laws or regulations which are not inconsistent with the provisions of this Agreement . . . .375

The Appellate Body has explained that determining whether a given measure is necessary to achieve a public policy objective involves weighing the following factors: (1) the contribution of the measure to the public policy objective it pursues; (2) the importance of the public policy objective; and (3) the degree to which the measure restricts trade. ${ }^{376}$ The first step of this analysis requires determining whether the measure genuinely contributes to a legitimate public policy objective. ${ }^{377}$ Assuming it does, and that the measure restricts trade, the second step requires determining whether there is a less trade-restrictive measure "reasonably available" that would achieve the respondent's "desired level of protection" pursued under that public policy objective, 378 a burden that falls on the complainant to establish. ${ }^{379}$ If the complainant establishes that there was a reasonably available alternative that achieved the same level of protection, then the measure was not "necessary" to pursue the legitimate public policy objective; if not, the necessity presumption stands.380 This formulation of the necessity defense makes sense, because it does not undermine the respondent's right to pursue legitimate public policy objectives; it just requires the respondent to account for WTO obligations when it chooses the appropriate measure to achieve those public policy objectives.

Similarly, an IIA between the European Union and the United States could have a general exceptions article explaining that a measure that is "necessary" to achieve a legitimate public policy objective excuses noncompliance with the IIA's other substantive obligations. Instead of assessing whether the measure is trade restrictive, as is required for the necessity inquiry under the WTO agreements, the inquiry under the IIA could focus on whether the measure interferes with "the establishment, acquisition, expansion, management, conduct, operation, and sale or other

375 GATS, supra note 374, art. XIV (emphasis added).

376 E.g., Appellate Body Report, India-Certain Measures Related to Solar Cells and Solar Modules, I 5.59, WTO Doc. WT/DS456/AB/R (adopted Sept. 16, 2016).

377 E.g., Appellate Body Report, Brazil-Measures Affecting Imports of Retreaded Tyres, ॠ 14145, WTO Doc. WT/DS332/AB/R (adopted Dec. 3, 2007) (quoting Appellate Body Report, United States-Measures Affecting the Cross-Border Supply of Gambling and Betting Services, II 306, WTO Doc. WT/DS285/AB/R (adopted Apr. 7, 2005)).

378 E.g., United States-Gambling and Betting Services, I 308 (emphasis added) (interpreting Article XIV of the GATS Agreement); Appellate Body Report, European Communities-Measures Affecting Asbestos and Asbestos-Containing Products, ๆ ๆ 173-75, WTO Doc. WT/DS135/AB/R (adopted Mar. 12, 2001) (interpreting Article XX(b) of the GATT 1994).

379 See, e.g., Brazil-Tyres, If 156 ("It rests upon the complaining Member to identify possible alternatives to the measure at issue that the responding Member could have taken.").

$380 \mathrm{Id}$. 
disposition of investments." 381 In other words, it would focus on whether the measure was investment-restrictive, and whether there was a reasonably available, less investment-restrictive measure that could achieve the same public policy objective. Indeed, CETA Article 28.3.2 includes the basis for such an article in an E.U.-U.S. IIA. In relevant part, it provides that:

For the purposes of ... Sections B (Establishment of investments) and C (Non-discriminatory treatment) of Chapter Eight (Investment), subject to the requirement that such measures are not applied in a manner which would constitute a means of arbitrary or unjustifiable discrimination between the Parties where like conditions prevail, or a disguised restriction on trade in services, nothing in this Agreement shall be construed to prevent the adoption or enforcement by a Party of measures necessary:

(a) to protect public security or public morals or to maintain public order;

(b) to protect human, animal or plant life or health; [or]

(c) to secure compliance with laws or regulations which are not inconsistent with the provisions of this Agreement .... ${ }^{382}$

This article does not go far enough, however, because it does not apply to all the host state's investment obligations; instead, it applies only to the nondiscrimination obligations and the obligations with respect to the establishment of an investment. 383 Under an E.U.-U.S. IIA, to ensure that a general exceptions article operated as a robust defense for host-state measures necessary to pursue legitimate public policy objectives, such an article should apply to all the host state's substantive obligations-especially the FET standard. The IIA would also need to modify the chapeau language in CETA Article 28.3.2 to remove the proviso about arbitrary or unjustifiable discrimination, because the FET standard already protects investors against that treatment. ${ }^{384}$ In other words, if that proviso were to remain, a host state's successful necessity defense against an FET claim could be overcome by a finding that the state accorded the same arbitrary or discriminatory treatment that grounded the FET claim. 385

3812012 U.S. Model BIT, supra note 25, arts. 3-4.

382 CETA, supra note 14, art. 28.3.2 (footnotes omitted).

383 See LESTER \& MERCURIO, supra note 328 , at 10 ("It is rather odd, to say the least, that the EU finds it necessary to include a general exception clause in relation to national treatment but not for other obligations such as expropriation and FET.").

384 See CETA, supra note 14, art. 8.10.2 (defining a breach of the obligation of fair and equitable treatment as including "manifest arbitrariness" and "targeted discrimination on manifestly wrongful grounds").

385 Cf. Barton Legum \& Ioana Petculescu, GATT Article XX and International Investment Law, in PRospects In InTERnATIONAL InVESTMENT LAW AND POLICY: WORLD TRADE FORUM 340, 355 (Roberto Echandi \& Pierre Sauvé eds., 2013) (“[I]t is difficult to imagine a measure that 
In summary, a general exceptions article should be included in an E.U.U.S. IIA because it would provide a concrete framework for determining when the host state's pursuit of public policy objectives excuses its noncompliance with its other treaty obligations, such as the FET standard. Such a general exceptions article in an E.U.-U.S. IIA would obviate the need for states to resort to the argument that their measures deserve a margin of appreciationa proposition that has proven controversial in investor-state jurisprudence. 386 By contrast, merely including a general provision, such as CETA Article 8.9.1, which provides that "the Parties reaffirm their right to regulate within their territories to achieve legitimate policy objectives,"387 imparts little guidance to tribunals on how they should resolve disputes when a host state breaches its substantive obligations in pursuit of a public policy objective. In other words, when CETA Articles 8.9.1 and 8.10 (Treatment of Investors and of Covered Investments) conflict, which one prevails? In turn, a general exceptions article should create more ex ante certainty for states and investors about the types of host-state measures that will be excused, and, therefore, should preempt arguments that the IIA will cause "regulatory chill."

\section{IMPLICATIONS OF THIS COMMENT'S PROPOSAL}

This Comment's proposed IIA between the United States and European Union represents a compromise between both parties' current international investment agreement negotiating positions. Specifically, it merges aspects of the European Union's Investment Court System with the United States' ad hoc arbitration system implemented in the USMCA. The Comment also recommends building on the FET standard that the European Union has included in its recent IIAs. This Part focuses on four important implications that follow from the Comment's proposal.

First, the Comment implies that ICSID would establish an appellate mechanism and facilitate the creation of a separate appellate instrument into which states could opt. There are sound reasons to believe that it would:

would be a violation of the FET standard and that would not also be viewed as arbitrary under [the chapeau of] GATT Article XX ....").

386 Compare Philip Morris Brands Sàrl, v. Oriental Republic of Uru., ICSID Case No. ARB/10/7 Award, I 399 (July 8, 2016), https://www.italaw.com/sites/default/files/case-documents/italaw7417.pdf [https://perma.cc/8X 3 Q-ZNEM] ("The Tribunal agrees with the Respondent that the 'margin of appreciation' is not limited to the context of the ECHR but 'applies equally to claims arising under BITs', at least in contexts such as public health."), with id., Concurring and Dissenting Opinion of Gary Born, I 87, https://www.italaw.com/sites/default/files/case-documents/italaw7428.pdf [https://perma.cc/2PAV-R29D] ("I also do not believe that the 'margin of appreciation' adopted by the Tribunal is either mandated or permitted by the BIT or applicable international law. The 'margin of appreciation' . . . cannot properly be transplanted to the BIT (or to questions of fair and equitable treatment more generally).").

387 CETA, supra note 14, art. 8.9.1. 
ICSID has proven to be a reliable supporter of ISDS reform efforts 388 and would likely embrace a role that promoted its own continued relevance in the international investment law regime. Moreover, the creation of an opt-in appellate mechanism at ICSID would not prejudice its ability to administer ad hoc arbitrations. 389

Second, by proposing the preservation of ad hoc arbitration in the first instance, the Comment implies that the European Union would relax its commitment to a first-instance Investment Court System modelspecifically, by abandoning a standing tribunal and by allowing investors to appoint arbitrators. As explained in subsection II.B.1, most of the features that define investor-state arbitration under the first tier of the European Union's Investment Court System resemble the features of ad hoc arbitration that the United States incorporated in the USMCA, suggesting that the European Union might accept the U.S. version of ad hoc arbitration. The more challenging issue: convincing the European Union that the IIA should permit each party to an arbitration-that is, the investor and the state-to appoint an arbitrator, as the European Union has argued that preventing investors from appointing arbitrators is necessary to enhance international investment law's legitimacy. 390 The counterargument to this position, which has been developed throughout this Comment, is that enabling investors to appoint arbitrators is necessary to ensure a neutral forum in which investorstate disputes can be resolved.

Third, this Comment's proposal would not upend current investor-state arbitration practice. The field's most skilled arbitrators would be eligible to serve on the appellate mechanism's roster of appellate adjudicators, provided they complied with conflict-of-interest rules enshrined in the IIA, which

388 For example, ICSID and UNCITRAL Working Group III collaborated to produce draft a Code of Conduct for Adjudicators. See ICSID and UNCITRAL Release Draft Code of Conduct for Adjudicators, INT'L CTR. FOR SETTLEMENT OF INV. DISPS. (May 1, 2020), https://icsid.worldbank.org/news-and-events/news-releases/icsid-and-uncitral-release-draft-codeconduct-adjudicators [https://perma.cc/96LA-QWX7] ("The draft Code was developed jointly by the ICSID and UNCITRAL Secretariats in the context of the work of UNCITRAL Working Group III (ISDS reform) and the process underway to amend ICSID's rules of procedure.").

389 To be sure, ICSID would need to add more staff to support an appeals mechanism. In this vein, it could draw on the WTO Secretariat's separation of its dispute settlement-support services into a Legal Affairs Division that supports dispute settlement panels and an Appellate Body Secretariat that supports the Appellate Body. See Divisions, WORLD TRADE ORG., https://www.wto.org/english /thewto_e/secre_e/div_e.htm [https://perma.cc/ $\left.5 \mathrm{R}_{37}-\mathrm{T}_{9} \mathrm{~W}_{5}\right]$ (explaining that the Legal Affairs Division "provide[s] legal advice and information to WTO dispute settlement panels, other WTO bodies, WTO members and the WTO Secretariat" and that the Appellate Body Secretariat "provides legal and administrative support to the Appellate Body").

390 See EUR. COMM'N, supra note 127, at 4 ("The installation of a permanent investment court system means that the parties can no longer choose their own arbitrators. This fundamentally corrects the economic incentives at play."). 
would mirror those in CETA and the USMCA. This model departs from the European Union's vision for a Multilateral Investment Court, whose adjudicators would be restricted to arbitrating disputes in that court system. ${ }^{391}$ In short, allowing adjudicators who complied with stringent conflict-of-interest rules to serve on the roster of appellate adjudicators and continue arbitrating other cases would likely attract the highest quality adjudicators-especially given that adjudicators on the appellate roster would have no guarantee of being selected to hear appeals. ${ }^{392}$

Fourth, the United States might resist this Comment's proposal to include a version of the FET standard in the E.U.-U.S. IIA that resembles the version the European Union included in CETA. The United States has endorsed tying fair and equitable treatment to the minimum standard of treatment under customary international law since at least 2001, when it, Canada, and Mexico issued the Joint Interpretive Note. ${ }^{393}$ And it has wired the customary international law version of fair and equitable treatment into the U.S. Model BIT. That said, the closed list of circumstances constituting a FET breach under CETA incorporates the types of state behavior that tribunals have found to breach the minimum standard under NAFTA,394 suggesting that there is not as much distance between the two parties' current formulation of the standard as there may appear. Thus, there are strong reasons to believe that the United States would accept the incorporation of the European Union's formulation of the FET standard in an E.U.-U.S. IIA. In turn, the adoption of the European Union's proposed FET language should promote more predictability in the resolution of investment disputes, thereby establishing the E.U.-U.S. IIA as an attractive model for other countries to draw on in negotiating their own IIAs.

\section{CONCLUSION}

The European Union and United States have a unique window of opportunity to reassert the legitimacy of international investment law and to

391 See European Union, Possible Reform, supra note 56, I 16 ("Adjudicators would be employed full-time. They would not have any outside activities.").

392 Cf. Gabrielle Kaufmann-Kohler \& Michele Potestà, The COMPOSition OF A MULTILATERAL INVESTMENT COURT AND OF AN APPEAL MECHANISM FOR INVESTMENT AWARDS \ 97 (2017) (reasoning that, under a roster-based appellate mechanism, "room would have to be made for the adjudicators' external activities, as a member of the roster would have no assurance of ever being appointed to a panel").

393 See supra note 152 and accompanying text.

394 See DUMBERRY, supra note 340 , at 104 ("[W] hat is probably the most striking feature of Article 8.10 CETA is the undeniable fact that the final list of elements it contains (and their actual contours) is to a very large extent based on how NAFTA tribunals have interpreted Article 1105 [NAFTA's minimum standard] over the last 20 years."). 
strengthen their own bilateral investment relationship in the process. The United States and the European Union must act on this issue now; if they punt, a polarized international investment law regime may follow, with the European Union's Investment Court System on the one hand and ad hoc arbitration or no ISDS mechanism on the other hand. Such a scenario would do little to promote the stability and predictability of FDI, which is a principal objective of international investment law and a driver of global growth.

This Comment proposed a structure for avoiding that scenario: the negotiation of an investment chapter that (1) creates a two-tiered ISDS system with an appellate mechanism and (2) harmonizes key substantive investment protection provisions. The proposed dispute resolution structure should satisfy the European Union and the United States, because an ICSID-based appeals mechanism would improve the correctness of ISDS awards and add institutional legitimacy to ISDS. Similarly, the harmonization of substantive provisions it has proposed should appeal to both parties, as it would generate more ex ante certainty for investors and states about the types of host-state measures that would breach substantive obligations and provide a coherent framework for determining when public policy measures excuse noncompliance with substantive obligations. 
